\title{
Enrico Frigeri
}

\section{Invasão por cães domésticos (Canis lupus}

familiaris) na Mata Atlântica: efeitos da perda de habitat e da intensificação agrícola

Invasion by domestic dogs (Canis lupus familiaris) in the Atlantic Forest: effects of habitat loss and agriculture intensification 


\title{
Enrico Frigeri
}

\section{Invasão por cães domésticos (Canis lupus}

\author{
familiaris) na Mata Atlântica: efeitos da \\ perda de habitat e da intensificação
}

\author{
agrícola
}

Invasion by domestic dogs (Canis lupus familiaris) in the Atlantic Forest: effects of habitat loss and agriculture intensification

Dissertação apresentada ao Instituto de Biociências da Universidade de São Paulo, para a obtenção de Título de Mestre em Ciências, na Área de Zoologia.

Orientadora: $\operatorname{Prof}^{\mathrm{a}}$. Dr ${ }^{\mathrm{a}}$. Renata Pardini

São Paulo 
Frigeri, Enrico

Invasão por cães domésticos (Canis lupus familiaris) na Mata Atlântica: efeitos da perda de habitat e da intensificação agrícola

Número de páginas: 92

Dissertação (Mestrado) - Instituto de Biociências da Universidade de São Paulo. Departamento de Zoologia.

1. Espécie exótica 2. Espécie invasora 3. Agroflorestas 4. Fragmentação de habitat 5. Características da paisagem 6. Mamíferos silvestres I. Universidade de São Paulo. Instituto de Biociências. Departamento de Zoologia.

\section{Comissão Julgadora:}




\section{Agradecimentos}

À Fundação de Amparo à Pesquisa do Estado de São Paulo pelo financiamento (processo 2005/56555-4), e pelas bolsas de estudo concedidas (processos 2011/03113-5, 2007/54888-1, 2005/57521-6 e 2009/02954-6). Ao Conselho Nacional de Desenvolvimento Científico e Tecnológico (CNPq) pela bolsa concedida (processo 135312/2011-6). Ao Programa de Cooperação Brasil Alemanha Ciência e Tecnologia para a Mata Atlântica $(\mathrm{CNPq} / \mathrm{BMBF}$ processo 690144/01-6), União Europeia, Ministério do Meio Ambiente e Seeds of Change pelos financiamentos. Ao programa PROEX-CAPES pela ajuda financeira para participação em dois congressos e para realização de uma viagem de campo.

À Renata Pardini por me orientar desde a graduação, por sete anos, sempre me ensinando e sempre pronta para me ajudar. Neste período, se tornou muito mais que uma orientadora, virou uma grande amiga. Obrigado por toda a dedicação, ensinamentos, paciência, em fim, por tudo durante esta caminhada, com certeza o que aprendi com você vou levar comigo para sempre.

À Universidade de São Paulo e ao Programa de Pós-Graduação em Zoologia do Instituto de Biociências da USP, em especial a Marcelo R. de Carvalho, pela disponibilidade e atenção durante todo este trabalho.

A Gustavo de Oliveira, Karina D. Espartosa e Camila Cassano, por gentilmente cederem grande parte dos dados utilizados neste mestrado, e por construírem em conjunto este trabalho. Sem os comentários e colaborações de vocês este trabalho não seria possível.

Ao Instituto de Estudos Socioambientais do Sul da Bahia por ceder os mapas da região de Una e Arataca, e à Paula K. Lira por ceder os mapas das paisagens do Planalto Atlântico de São Paulo.

Aos proprietários das localidades onde o estudo foi realizado, por permitirem o acesso e a coleta dos dados. Aos trabalhadores e moradores que nos receberam, pela ajuda em campo, receptividade, histórias e pelos cafés e bolos.

Aos colegas do Laboratório de Diversidade e Conservação de mamíferos: Patricia Torres, Thomas Püttker, Paula K. Lira, Camila Cassano, Bruno T. Pinotti, Camila S. de Barros, Natalia Rossi, Gustavo de Oliveira, Camilla P. Pagotto, Thais K. 
Martins, Juliana R. de Luca, Karina D. Espartosa, Paula Elias Moraes, Karina C. Tisovec, Gabriela de L. Marin, Leila Z. Telles, Marina X. da Silva, pela disponibilidade em ajudar, parceria, comentários e sugestões. Em especial à Paula K. Lira e Patrícia Torres pela ajuda de custo para apresentação do trabalho no $50^{\circ}$ ATBC, realizado na Costa Rica.

A Thomas Püttker por sempre estar disposto a me ajudar e por tanto se esforçar para a realização dos seminários semanais do Laboratório, ótima oportunidade para discussão e aprendizado.

Aos companheiros de monitoria da disciplina "Diversidade, História Natural e Conservação de Vertebrados na América do Sul - BIZ 0304" do Instituto de Biociências da USP: Thomas Püttker, Patricia Torres, Paula K. Lira, Carlos Eduardo Benfica e Francisco V. Dénes, pelo bom humor que deixou a tarefa mais tranquila.

A Leandro Tambosi e Thomas Puettker pelas ajudas com o programa ArcGis. À Patricia Torres pela ajuda com o R, compartilhando e debatendo scripts. A Gustavo de Oliveira pelo companheirismo, amizade e aprendizado em campo e por todas as risadas e encrencas que nos metemos.

Aos amigos do curso de campo da Mata Atlântica 2011 que fizeram um mês que tinha tudo para ser complicado ser bem mais "tranquilooo". Em especial a Gabriel Frey, Paula Lemos, Paula Ramos Sicsu, Erika Marques de Santana, Mariana M. Vidal, Bárbara Henning, Solimary Garcia Hernandez, Mathias M. Pires e Tiago Evangelista. Também agradeço a todas as outras pessoas com as quais realizei disciplinas, pelos debates e discussões com os quais tanto aprendi.

Aos professores Paulo Inácio Prado, Glauco Machado, Alexandre A. de Oliveira, Paulo Guimarães, Luís Schiesari, Paulo T. Sano, João Luís F. Batista, Jean Paul Metzger, pelas disciplinas oferecidas e pelo aprendizado.

À Adriana M. P. M. Pardini e Rafael Reis por revisar o inglês de ambos os capítulos.

E por fim, à minha família, em especial aos meus pais, José A. Frigeri e Silvia Coari, e ao meu irmão e grande parceiro, Frederico Frigeri, pelo apoio incondicional, por sempre estarem ao meu lado, e serem responsáveis, em grande parte, pelo que sou hoje.

\section{Obrigado!}




\section{Índice}

$\begin{array}{ll}\text { Resumo } & 01\end{array}$

$\begin{array}{ll}\text { Abstract } & 03\end{array}$

$\begin{array}{ll}\text { Introdução geral } & 04\end{array}$

Capítulo 1. Domestic dog invasion in Atlantic forest fragmented landscapes

Abstract 20

$\begin{array}{ll}\text { Resumo } & 21\end{array}$

$\begin{array}{ll}\text { Introduction } & 21\end{array}$

$\begin{array}{ll}\text { Methods } & 24\end{array}$

Results $\quad 29$

Discussion 33

$\begin{array}{ll}\text { References } & 38\end{array}$

Capítulo 2. Do conversion of native forests into agroforests and agroforestry intensification favor the invasion of domestic dogs?

$\begin{array}{ll}\text { Abstract } & 62\end{array}$

$\begin{array}{ll}\text { Resumo } & 63\end{array}$

Introduction $\quad 64$

$\begin{array}{ll}\text { Methods } & 66\end{array}$

$\begin{array}{ll}\text { Results } & 70\end{array}$

$\begin{array}{ll}\text { Discussion } & 72\end{array}$

$\begin{array}{ll}\text { References } & 75\end{array}$

$\begin{array}{ll}\text { Considerações finais } & 90\end{array}$ 


\section{Resumo}

Invasões biológicas são consideradas uma das maiores ameaças atuais à biodiversidade global. O cão doméstico é hoje o carnívoro mais abundante no mundo, e tem invadido áreas de vegetação nativa, podendo causar impactos negativos à fauna silvestre através da predação, competição e transmissão de doenças. A partir de dois extensos bancos de dados obtidos através de armadilhas fotográficas, esta dissertação pretende contribuir com o entendimento das causas e consequências da invasão por cães domésticos de remanescentes florestais e agroflorestas na Mata Atlântica. A dissertação está organizada em dois capítulos. No primeiro, usamos dados obtidos em duas paisagens rurais do Planalto Atlântico de São Paulo com diferentes proporções de florestas remanescentes, e (1) descrevemos o tipo de manejo e as características dos cães que visitam fragmentos florestais, (2) comparamos, entre estas paisagens, a frequência e horário de visitas e o tamanho de grupos de cães invasores assim como os fatores determinantes da intensidade de invasão, e (3) investigamos o impacto da intensidade de invasão sobre a distribuição de mamíferos silvestres de maior porte. No segundo capítulo, usamos dados obtidos em um mosaico agroflorestal do Sul da Bahia, e (4) verificamos se a conversão de florestas nativas em agroflorestas e a intensificação das agroflorestas favorecem a invasão por cães domésticos, e (5) se a invasão por estes animais está mais associada à presença humana nas agroflorestas do que nas florestas. Em conjunto, os resultados dessa dissertação sugerem que: (1) a intensidade da invasão por cães em paisagens antropizadas de Mata Atlântica é altíssima, tanto em termos do número de indivíduos e de visitas como em termos do número de sítios ocupados; (2) a invasão é favorecida pelo tipo de manejo dos animais, que são em grande parte criados soltos, e parece estar fortemente associada à presença do homem; (3) a intensidade de invasão afeta negativamente a distribuição de um maior número de espécies de mamíferos de maior porte do que a perda de $40 \%$ de floresta na paisagem; (4) características dos remanescentes florestais associadas à perda de habitat (quantidade e qualidade dos remanescentes) são mais importantes que a pressão de propágulo para determinar a intensidade da invasão; (5) a intensificação do manejo de agroflorestas acentua a invasão. Visto que a intensificação de agroflorestas e de outros sistemas agrícolas vem se acentuando globalmente e que, apesar da diminuição das taxas de desmatamento das florestas tropicais nos últimos anos, a maior parte das áreas remanescentes é constituída de 
vegetação degradada ou secundária, a quantidade de áreas susceptíveis à invasão e os danos causados por cães domésticos devem aumentar no futuro. 
Biological invasions are considered one of the most important threats to global biodiversity. Domestic dogs, the most abundant carnivore in the world, are known to invade areas of native vegetation and impact wildlife through competition, predation and disease transmission. Drawing on two extensive dataset obtained through cameratrapping, this dissertation intends to contribute to the understanding of the causes and consequences of the invasion by domestic dogs of forests fragments and agroforests in the Atlantic Forest. The dissertation is organized into two chapters. In the first chapter, we use data from two rural landscapes of São Paulo Atlantic Plateau with different proportions of remaining forests, and (1) describe the management and the characteristics of dogs that visit forest fragments, (2) compare, between these landscapes, the frequency and time of visits, the size of groups of invading dogs, and the drivers of invasion intensity, and (3) investigate the impacts of invasion intensity on the distribution of native large mammals. In the second chapter, using data from an agroforestry mosaic in southern Bahia, we investigate (4) if the conversion of native forests into agroforests and agroforestry intensification favor the invasion by dogs, and (5) if invasion by these animals is more associated with human presence in agroforests than in forests. Our findings highlight that: (1) the intensity of the invasion by dogs in human-modified landscapes in the Atlantic Forest is extremely high, both in terms of the number of individuals and of visits and in terms of the number of occupied sites; (2) invasion is favored by the type of management, with dogs kept free, and seems to be strongly associated with the presence of humans; (3) invasion intensity negatively affects the distribution of a larger number of large mammals than the loss of $40 \%$ of forest in the landscape; (4) characteristics of forest fragments associated with habitat loss (quantity and quality of remnants) are more important than propagule pressure to determine the intensity of invasion; (5) management intensification in agroforests intensifies invasion. As intensification of agroforestry and other agricultural systems has increased globally and, despite the decrease in the rates of deforestation in recent years, most tropical forest remnants consist of degraded or secondary vegetation, the amount of areas susceptible to invasion and the damages caused by domestic dogs should increase in the future. 


\section{Introdução geral}

Espécies nativas de uma região são aquelas que ali ocorrem naturalmente, ou seja, cuja dispersão e estabelecimento ocorreram independentemente de atividades humanas. No geral, espécies que ocorrem em uma região desde o Período Neolítico podem ser consideradas nativas (IUCN, 1987). Da mesma forma, espécies que expandiram recentemente sua área de distribuição sem nenhum auxílio (intencional ou não) do homem também são consideradas nativas (Conover, 2002), sendo o processo de expansão conhecido como invasões espontâneas (Manchester \& Bullock, 2000). Por outro lado, espécies exóticas são aquelas que não ocorrem naturalmente em uma área e cuja dispersão foi resultado de uma atividade humana (IUCN, 1987; Temple 1992; Holmes \& Simons, 1996). No geral, espécies que colonizaram uma nova área, com exceção das invasões espontâneas, após o Período Neolítico, aproximadamente 6000 anos A.C., são consideradas exóticas (Webb, 1985). Por fim, espécies exóticas invasoras são aquelas que se estabelecem em uma nova área de ocorrência onde proliferam e se distribuem (Mack et al., 2000), podendo causar prejuízos econômicos, ambientais ou ao bem estar humano (MMA, 2011).

Desde que o homem viaja através e entre continentes, as espécies tem sido transportadas, intencionalmente ou não, para novas áreas de distribuição (Manchester \& Bullock, 2000). Desta forma, temos introduzido, por centenas de anos, plantas, animais e outros organismos ao redor do mundo, em um processo relativamente lento de globalização da biota da Terra (DiCastri, 1989). Porém, mais recentemente, tanto o desenvolvimento de novas tecnologias que melhoraram o transporte, quanto o processo de globalização, facilitaram o comércio internacional, a criação de novas rotas, mercados e produtos, e o movimento de seres humanos, aumentando grandemente a dispersão e invasão de espécies ao redor do globo (Levine \& D’Antonio, 2003; Ruiz \& Carlton, 2003; Meyerson \& Mooney, 2007; Hulme, 2009; Hulme et al., 2009).

Segundo Lockwood (1999) três grupos de espécies são mais beneficiados com esta grande mobilidade humana e mercantil. O primeiro grupo inclui as plantas e animais que são deliberadamente levados pelo homem quando ocupamos uma nova área. Desta forma, plantas frutíferas, vegetais e animais domésticos são transportados através do mundo. Tais organismos geralmente são mantidos próximos aos locais de estabelecimento das populações humanas e recebem cuidados. Os animais são 
transportados para recreação, alimentação, educação e pesquisas, porém alguns são soltos deliberadamente na natureza ou conseguem fugir de seus cativeiros e recintos. $\mathrm{O}$ segundo grupo de espécies são aquelas importadas de outras regiões com a intenção de serem liberadas na natureza para estabelecerem uma população livre, por razões estéticas, ou para o fornecimento de comida, fibras, ou de oportunidades de caça. $\mathrm{O}$ terceiro e último grupo de espécies proposto por Lockwood (1999) compreende os organismos transportados pelo homem sem que estes tenham ciência. Este grupo inclui parasitas e vetores de doenças, os quais infectam pessoas, animais e plantas que viajam ao redor do mundo, e animais pequenos como ratos, cobras e insetos, que são transportados junto com mercadorias e outros bens. Desta forma, a introdução de uma nova espécie pode ser acidental ou intencional (Manchester \& Bullock, 2000).

Apesar da grande quantidade de espécies e organismos transportados para novas áreas por ações antrópicas, poucas se tornam espécies invasoras. No geral, cerca de 0,1\% das espécies importadas para uma nova região se tornam invasoras (Williamson, 1992, 1993). Porém, em vários casos a proporção pode ser bem mais alta (Williamson \& Fitter, 1996; Williamson 1996). Características morfológicas, fisiológicas e da história de vida parecem determinar quais espécies são invasoras eficientes (Manchester \& Bullock, 2000). Por exemplo, árvores invasoras do gênero Pinus possuem maior massa de sementes, crescimento mais rápido e maior frequência de liberação de sementes do que as não invasoras (Rejmánek \& Richardson, 1996). Segundo Ehrlich (1986), diversas espécies de vertebrados invasores possuem hábitos alimentares generalistas, curto tempo de geração, alta habilidade de locomoção, grande variação genética populacional e alta plasticidade ecológica.

Outro fator que pode influenciar no sucesso de uma invasão é a vulnerabilidade da área alvo (Conover, 2002). Apesar de que todas as comunidades ecológicas podem, em certa medida, sofrer invasões biológicas (Crawley, 1987; Usher et al. 1988), características do habitat e fatores ambientais podem ser mais importantes do que características das espécies para determinar o sucesso de uma invasão (Newsome e Noble, 1986). É amplamente aceito que ambientes alterados pelo homem são mais facilmente invadidos (Newsome e Noble, 1986; Smallwood, 1994) e que distúrbios, tanto em escala ampla como local, são importantes na facilitação de invasões (Sher \& Hyatt, 1999; Mooney \& Hobbs, 2000; D’Antonio \& Meyerson, 2002). Por outro lado, locais com pouca perturbação humana e com uma grande riqueza de espécies nativas tendem a conter poucas espécies invasoras (Conover, 2002). A maior probabilidade de 
que áreas perturbadas apresentem recursos não utilizados, dado o efeito de distúrbios sobre espécies nativas, e que não abriguem agentes controladores, como predadores e competidores, podem ser as razões para a maior vulnerabilidade à invasão (Cox, 1999; Conover, 2002). No entanto, a probabilidade de invasão também depende da pressão de propágulos da espécie invasora (Groves \& Burdon, 1986; Leung et al., 2004) e de fatores geográficos como o isolamento e o tamanho da área invadida (Crawley 1987).

Mesmo que apenas uma pequena porcentagem de todas as espécies transportadas se torne invasora, as invasões biológicas representam uma ameaça significativa à biodiversidade terrestre (McGeoch et al., 2010) e a magnitude desta ameaça está aumentando globalmente (Hulme, 2009). Para alguns autores, a introdução de espécies exóticas invasoras é a segunda maior ameaça à biodiversidade global, estando atrás apenas da perda e destruição dos habitats (Elton, 1958; Vitousek et al., 1997, Baillie et al., 2004). Espécies invasoras alteram processos dos ecossistemas (Raizada et al., 2008), mudam a estrutura das comunidades (Hejda et al., 2009), alteram a diversidade genética de populações (Ellstrand \& Schierenbeck, 2000), diminuem a abundância e riqueza de espécies nativas através da competição, predação, herbivoria, hibridização, transmissão de doenças e parasitas e através de outros efeitos indiretos (Wattaola et al., 1996; Oldroyd, 1999; Blackburn et al., 2004; Gaertner et al., 2009), ou ainda, alteram o comportamento de indivíduos, como por exemplo, mudanças no período de atividade e nos níveis de vigilância (Altendorf et al., 2001; Pyare \& Berger, 2003; Creel \& Christianson, 2008). Um número relativamente pequeno de espécies invasoras está gradualmente substituindo as espécies nativas que estão desaparecendo como consequência das atividades humanas (Rodríguez, 2001), levando a uma gradual homogeneização da biota (McKinney \& Lockwood 1999; Rahel, 2000). Um estudo feito em 57 países levantou 542 espécies invasoras, sendo 316 plantas vasculares, 101 marinhas, 44 peixes de água doce, 43 mamíferos, 23 aves e 15 anfíbios (McGeoch et al., 2010). Porém, apenas no Brasil já foram registradas aproximadamente 647 espécies invasoras (MMA, 2011).

Entre as espécies invasoras mais comuns está o cão doméstico (Canis lupus familiaris), introduzido onde quer que o homem tenha se fixado (Wandeler et al. 1993; Pimentel et al., 2000) e trazido para a América do Sul por colonizadores europeus (Clutton-Brock, 1996). O sucesso da expansão das populações humanas pelo globo está em parte ligado à domesticação deste animal (Miklósi, 2007; Clutton-Brock, 2008; Morey, 2010), que atualmente é o carnívoro mais comum do mundo (Vanak \& 
Gompper, 2010). Originou-se na Ásia a partir de lobos (Canis lupus) (Savolainen et al., 2002), e o processo de domesticação resultou em mudanças no tamanho corporal e na configuração crânio-dentária (Clutton-Brock, 2008; Coppinger \& Schneider, 1995) que possibilitaram o consumo de uma grande variedade de tipos de alimentos, desde lixo até presas silvestres (Vanak \& Gompper, 2009a). Hoje recebem do homem alimentação, proteção contra predadores e cuidados veterinários (Butler \& du Toit 2002; Vanak \& Gompper, 2009a), o que permite que atinjam alta densidade populacional (Vanak \& Gompper, 2010). Além de receber esses subsídios, os cães apresentam eficiência na dispersão (Pal et al., 1998), e rápido aumento populacional em condições favoráveis (Lodge, 1993; Pullin, 2002), características que podem favorecer o estabelecimento e invasão em novas áreas.

Cães domésticos têm atuado como espécie exótica invasora, perturbando e modificando ecossistemas nativos de diferentes maneiras (Clout 1995). Na maior parte do globo, os cães domésticos apresentam alguma forma de comportamento de vida livre (Wandeler et al., 1993; Vanak \& Gompper, 2009a; Torres \& Prado, 2010). Esta tendência se acentua em regiões rurais, onde os cães além de serem mantidos livres (Brooks, 1990; Kitala et al., 2001; Campos et al., 2007; Ortega-Pacheco et al., 2007; Torres, 2008) não recebem supervisão e cuidados veterinários (Butler \& Bingham, 2000; Kitala et al., 2001; Torres 2008). Assim, hoje se sabe que cães domésticos interagem com animais selvagens seja como predadores (Butler et al., 2004; Galetti e Sazima 2006; Campos et al., 2007), presas (Mukherjee \& Sharma, 2001; Edgaonkar \& Chellam, 2002; Singh et al., 2007; Goldenberg, 2008), competidores por exploração (Sillero-Zubiri \& Macdonald, 1997; Butler \& du Toit, 2002; Aiyadurai \& Jhala, 2006), competidores por interferência (Boitani et al., 1995; Vanak \& Gompper, 2009b), reservatórios e/ou transmissores de doenças e parasitas (Cleaveland et al., 2000; Funk et al., 2001; Van de Bildt et al., 2002; Fiorello et al., 2006; Whiteman et al., 2007). Em alguns casos, tais interações são a causa de reduções drásticas de populações de diversos mamíferos silvestres (Barret, 1999), como por exemplo, o cão-selvagem-africano (Lycaon pictus) (Van de Bildt et al. 2002), os leões (Panthera leo) do Parque Nacional do Serengueti na Tanzânia (Roelke-Parker et al. 1996; Packer et al. 1999; Cleaveland et al. 2000), o lobo-etíope (Canis simensi) (Sillero-Zubiri et al.,1996; Whitby et al., 1997; Randall et al., 2006), o lobo-europeu (Canis lupus) na Itália (Boitani \& Ciucci, 1995), a foca-do-cáspio (Phoca caspica) (Kennedy et al., 2000) e a gazela-da-montanha (Gazella gazella) em Israel (Manor \& Saltz, 2004). 
Apesar dos problemas que cães domésticos causam às espécies silvestres, os estudos sobre a invasão de cães domésticos no Brasil são bastante recentes. Considerando que ambientes alterados são mais facilmente invadidos (Newsome e Noble, 1986; Smallwood, 1994) e que distúrbios facilitam a invasão de espécies (Sher \& Hyatt, 1999; Mooney \& Hobbs, 2000; D’Antonio \& Meyerson, 2002), a Mata Atlântica Brasileira, que atualmente foi reduzida a menos de $16 \%$ de sua cobertura original (Ribeiro et al., 2009) distribuída em fragmentos pequenos, isolados e muitas vezes perturbados (Câmara, 2005; Moore, 2005), e que abriga boa parte da população brasileira, é um bioma vulneral à invasão e aos danos causados por cães domésticos. No entanto, a maioria dos estudos realizados no Brasil foi conduzida em áreas protegidas ou em ambiente periurbano (Horowitz, 1992; Monteiro-Fillho, 1995; Marinho-Filho et al.,1998; Lacerda, 2002; Rodrigues, 2002; Gaspar, 2005; Negrão \& Valladares-Pádua, 2006; Campos et al., 2007; Whiteman et al., 2007; Oliveira et al., 2008; Srbek-Araujo \& Chiarello, 2005 e 2008; Lacerda et al., 2009), sendo que poucos foram realizados em áreas rurais não protegidas da Mata Atlântica (Galetti \& Sazima, 2006; Torres, 2008; Torres \& Prado, 2010), locais relativamente mais expostos a invasão por cães domésticos.

Os estudos realizados até o momento no Brasil indicam que cães domésticos são potenciais transmissores de doenças, como a cinomose e a raiva, para carnívoros nativos (Courtnay et al., 2001; Whiteman et al., 2007), estão presentes (Monteiro-Fillho, 1995; Lacerda, 2002; Alves \& Andriolo, 2005; Srbek-Araujo \& Chiarello, 2005; Negrão \& Valladares-Pádua, 2006; Torres, 2008), e podem estar entre as espécies de mamíferos mais frequentes (Gaspar, 2005; Srbek-Araujo \& Chiarello, 2008; Lacerda et al. 2009; Torres \& Prado, 2010) em áreas de vegetação nativa, e ainda, podem predar a fauna silvestre nativa (Horowitz, 1992; Marinho-Filho et al.,1998; Rodrigues, 2002; Galetti \& Sazima, 2006; Campos et al., 2007; Oliveira et al., 2008). Alguns trabalhos demonstram que a ocorrência ou frequência de visitas de cães são mais frequentes nas bordas das áreas de vegetação nativa (Lacerda, 2002; Srbek-Araujo \& Chiarello, 2008; Lacerda et al., 2009; Torres \& Prado, 2010). Nos poucos casos em que se investigou a relação entre registros de cães e de mamíferos silvestres, observou-se que a presença ou frequência dos cães está negativamente relacionada à frequência de espécies de mamíferos silvestres (Lacerda, 2009; Cassano et al., in press).

Todos estes estudos, no entanto, têm um escopo espacial relativamente pequeno e/ou não identificaram indivíduos, apenas registraram a espécie, e consequentemente 
não trazem informações sobre a abundância de cães dentro e fora de áreas de vegetação nativa, padrões espaciais e temporais de deslocamento dos indivíduos em áreas nativas, ou as características dos indivíduos que frequentemente visitam essas áreas, todas importantes para se compreender os impactos e os fatores que condicionam a invasão por cães domésticos. Este trabalho se baseia em dois extensos bancos de dados obtidos através de amostragem padronizada com armadilhas fotográficas em duas regiões da Mata Atlântica e visa contribuir com o entendimento das causas e consequências da invasão por cães domésticos. Abordamos a relação da invasão de cães com a perda de habitat e a intensificação da agricultura e trazemos informações que podem auxiliar a minimizar os impactos causados por cães domésticos à fauna silvestre de florestas tropicais.

A dissertação está dividida em dois capítulos, um centrado na invasão de remanescentes florestais em duas paisagens com diferentes proporções de floresta remanescente no Planalto Atlântico Paulista, e outro na invasão de florestas e agroflorestas em um mosaico agroflorestal no Sul da Bahia. No primeiro capítulo, os objetivos foram descrever a forma de manejo e as características físicas dos cães que visitam os fragmentos florestais; comparar as características da invasão, em termos da frequência e horário de visitas e tamanho de grupos, entre paisagens com diferentes proporções de florestas remanescentes; investigar a importância relativa de fatores em escala local, como a quantidade e qualidade da floresta e o número de cães criados no entorno, e suas interações com a quantidade de floresta na escala da paisagem, para a determinação da intensidade da invasão por cães domésticos; e por fim, avaliar o impacto da intensidade de invasão, em termos do número de cães invasores, e sua interação com a quantidade de floresta na escala da paisagem sobre a distribuição de mamíferos silvestres de maior porte. Já no segundo capítulo, investigamos se a conversão de florestas nativas em agroflorestas e a intensificação do manejo de agroflorestas favorecem a invasão por cães domésticos e se a invasão por estes animais exóticos está mais associada à presença humana nas agroflorestas do que nas florestas. Os dois capítulos foram redigidos em formato de artigo científico em inglês.

\section{Referencias Bibliográficas}

Aiyadurai, A. \& Jhala, Y.V. 2006. Foraging and habitat use by golden jackals (Canis aureus) in the Bhal Region, Gujarat, India. Journal of the Bombay Natural History Society 103: 5-12. 
Altendorf, K.B., Laundre, J.W., Lopez Gonzalez, C.A., Brown, J.S. 2001. Assessing effects of predation risk on foraging behavior of mule deer. J. Mammal 82:430439.

Alves, L.C.P.S. \& Andriolo, A. 2005. Camera traps use on the mastofaunal survey of Araras Biological Reserve, IEF-RJ. Revista Brasileira de Zoociências 7 (2): 231246.

Baillie J.E.M., Hilton-Taylor C., Stuart S.N. (Eds). 2004. 2004 IUCN Red List of Threatened Species. A Global Species Assessment. IUCN, Gland, Switzerland and Cambridge, UK.

Barrett, T. 1999. Morbillivirus infections, with special emphasis on morbilliviruses of carnivores. Veterinary Microbiology 69: 3-13.

Blackburn, T.M., Cassey, P., Duncan, R.P., Evans, K.L., Gaston, K.J. 2004. Avian extinction and mammalian introductions on oceanic islands. Science 305: 19551958.

Boitani, L. \& Ciucci, P. 1995. Comparative social ecology of feral dogs and wolves. Ethol. Ecol. Evol. 7: 49-72.

Boitani, L., Francisci, F., Ciucci, P., Andreoli, G. 1995. Population biology and ecology of feral dogs in central Italy. In: Serpel, J. (Eds) The Domestic Dog. Its Evolution, Behaviour, and Interactions with People, Cambridge University Press, Cambridge, UK. p. 217-244.

Brooks, R. 1990. Survey of the dog population of Zimbabwe and its level of rabies vacination. Veterinary Research 127: 592-596.

Butler, J.R.A., Birgham, J. 2000. Demography and dog-human relationships of the dog population in Zimbabwean communal lands. The Veterinary Record 147: 442-446.

Butler, J. R. A. \& du Toit, J.T. 2002. Diet of free-ranging domestic dogs (Canis familiaris) in rural Zimbabwe: implications for wild scavengers on the periphery of wildlife reserves. Animal Conservation 5: 29-37.

Butler, J.R.A., du Toit, J.T., Bingham, J. 2004. Free-ranging domestic dogs (Canis familiaris) as predators and prey in rural Zimbabwe: threats of competition and disease to large wild carnivores. Biological Conservation 115: 369-378.

Câmara, I.G. 2005. Breve história da conservação da Mata Atlântica. In: Galindo-Leal C., Câmara I. de G. (Eds). Mata Atlântica: biodiversidade, ameaças e perspectivas. Fundação SOS Mata Atlântica, São Paulo; Conservação Internacional, Belo Horizonte. 
Campos, C.B., Esteves, C.F., Ferraz, K.M.P.M.B., Crawshaw, Jr. P.G., Verdade, L.M. 2007. Diet of free-ranging cats and dogs in a suburban and rural environment, south-eastern Brazil. Journal of Zoology 273: 14-20.

Cassano, C.R., Barlow, J., Pardini, R. In press. Forest loss or management intensification? Identifying causes of mammal decline in cacao agroforests. Biological Conservation.

Cleaveland, S., Appel, M.G.J., Chalmers, W.S.K., Chillingworth, C., Kaare, M., Dye, C. 2000. Serological and demographic evidence for domestic dogs as a source of canine distemper virus infection for Serengeti wildlife. Veterinary Microbiology 72: $217-227$.

Clout, M. 1995. Introduced species: the greatest threat to biodiversity? Species 24: 3436.

Clutton-Brock, J. 1996. Competitors, companions, status symbols, or pests. A review of human association with other carnivores. In: Carnivore Behavior, Ecology, and Evolution vol. 2. Cornell University Press, New York, 644 pp.

Clutton-Brock, J. 2008. Origins of the dog: domestication and early history. In: Serpell, J. (Ed.). The domestic dog: Its evolution, behaviour, and interactions with people. Cambridge University Press, Cambridge. p 7-20p.

Conover, M. 2002. Resolving human-wildlife conflicts: the science of wildlife damage management. Lewis Publishers. 418 p.

Coppinger, R. \& Schneider, R. 1995. Evolution of working dogs. In: Serpell, J. (Eds) The Domestic Dog. Its Evolution, Behaviour, and Interactions with People. Cambridge University Press, Cambridge, UK. p. 21-47.

Courtnay, O., Quinnel, R.J., Chalmers, W.S.K. 2001. Contact rates between wild and domestic canids: no evidence of parvovirus or canine distemper virus in crab-eating foxes. Vet. Microbiol. 81(1): 9-19.

Cox, G. W. 1999. Alien species in North America and Hawaii. Island Press, Washington, D.C.

Crawley, M.J. 1987. What makes a community invasible? Colonization, Succession and Stability. In: Gray, A. J., Crawley, M. J., Edwards, P.J. (Eds). Blackwell Scientific Publications, Oxford, UK. p. 429-453.

Creel, S. \& Christianson, D. 2008. Relationships between direct predation and risk effects. Tree 23:194-201. 
D’Antonio, C.M. \& Meyerson, L.A. 2002. Exotic plant species as problems and solutions in ecological restoration: a synthesis. Restor. Ecol. 10: 703-713.

DiCastri, F. 1989. History of biological invasions with special emphasis on the Old World. In: Drake, J.A., Mooney, H.J., DiCastri, F., et al. (Eds). Biological invasions: a global perspective. Chichester, UK.

Edgaonkar, A. \& Chellam, R. 2002. Food habit of the leopard, Panthera pardus, in the Sanjay Gandhi National Park, Maharashtra, India. Mammalia 66: 353-360.

Ehrlich, P.R. 1986. Which animal will invade? Ecology of Biological Invasions of North America and Hawaii. In: Mooney, H.A. \& Drake, J.A. (Eds). Ecological Studies 58. Springer-Verlag, New York. p. 79-95.

Ellstrand, N.C. \& Schierenbeck, K.A. 2000. Hybridization as a stimulus for the evolution of invasiveness in plants? Proceedings of the National Academy of Sciences of the United States of America 97: 7043-7050.

Elton, C.S. 1958. The Ecology of Invasions by Animals and Plants. Methuen \& Co., London.

Fiorello, C.V., Noss, A.J., Deem, S.L. 2006. Demography, hunting ecology, and pathogen exposure of domestic dogs in the Isoso of Bolivia. Conservation Biology 20: 762-771.

Funk, S.M., Fiorello, C.V., Cleaveland, S., Gompper, M.W. 2001. The role of disease in carnivore ecology and conservation. In: Gittleman, J. L, Funk, S. M., MacDonald, D. W. , Wayne, R. K. (Eds.) Carnivore Conservation, Cambridge University Press, Cambridge, UK. p. 443-466.

Gaertner, M., Den Bree, A., Hui, C., Richardson, D.M. 2009. Impacts of alien plant invasions on species richness in Mediterranean-type ecosystems: a meta-analysis. Progress in Physical Geography 33: 319-338.

Galetti, M. \& Sazima, I. 2006. Impact of feral dogs in an urban Atlantic Forest fragment in southeastern Brazil. Natureza e Conservação 4 (1): 146-151.

Gaspar D. A. 2005. Comunidade de mamíferos não voadores de um fragmento de Floresta Atlântica semidecídua do Município de Campinas, SP. Tese de Doutorado em Ecologia. Universidade Estadual de Campinas, Campinas, Brasil.

Goldenberg, S. 2008. Bear attack on Uncompahgre Plateau (Colorado) kills dog. In: KJCT8 News. http://www.kjct8.com/Global/story.asp?S=8913374. Acessado em: 27 de Agosto de 2009. 
Groves, R.H. \& Burdon, J.J. 1986. Ecology of Biological Invasions: An Australian Perspective. Australian Academy of Science, Canberra. 166 p.

Hejda, M., Pysek, P., Jarosik, V. 2009. Impact of invasive plants on the species richness, diversity and composition of invaded communities. Journal of Ecology 97: 393-403.

Holmes, J.S. \& Simons, J.R. 1996. The Introduction and Naturalisation of Birds. HMSO, London, UK.

Horowitz C. 1992. Plano de Manejo do Parque Nacional de Brasília: avaliação da Metodologia de Planejamento adotada, Execução e Resultados Alcançados no decânio 79/89. Dissertação de Mestrado. Universidade de Brasília, Brasília, Brasil.

Hulme, P.E. 2009. Trade, transport and trouble: managing invasive species pathways in an era of globalization. Journal of Applied Ecology 46: 10-18.

Hulme, P.E., Pysek, P., Nentwig, W., Vilà , M. 2009. Will threat of biological invasions unite the European Union? Science 324: 40-41.

IUCN (International Union for the Conservation of Nature). 1987. The IUCN position statement on translocation of living organisms. IUCN, Gland, Switzerland.

Kennedy, S., Kuiken, T., Jepson, P.D., Deaville, R., Forsyth, M., Barrett, T., Van de Bildt, M.W.G., Osterhaus, A.D.M.E., Eybatov, T., Duck, C., Kydyrmanov, A., Mitrofanov, I., Wilson, S. 2000. Mass die-off of Caspian seals caused by Canine distemper virus. Emerging Infectious Diseases 6: 637-639.

Kitala, P., McDermott, J., Kyule, M., Gathuma, J., Perry, B., Wandeler, A. 2001. Dog ecology and demography information to support the planning of rabies control in Machacos District, Kenya. Acta Tropica 78: 217-230.

Lacerda, A.C.R. 2002. Análise de Ocorrência de Canis familiaris no Parque Nacional de Brasília: influência da matriz, monitoramento e controle. Dissertação de Mestrado em Ecologia, Instituto de Ciências Biológicas, Universidade de Brasília, Brasília, Brasil.

Lacerda, A.C.R., Tomas, W.M., Marinho-Filho, J. 2009. Domestic dogs as an edge effect in the Brasília National Park, Brazil: interactions with native mammals. Animal Conservation 12: 477-487.

Leung, B., Drake, J.M., Lodge, D.M. 2004. Predicting invasions: propagule pressure and the gravity of allee effects. Ecology 85(6):1651-1660.

Levine, J.M. \& D’Antonio, C.M. 2003. Forecasting biological invasions with increasing international trade. Conservation Biology 17: 322-326. 
Lodge, D.M. 1993. Biological invasions: lessons for ecology. Trends in Ecology and Evolution 8(4):133-137.

Loockwood, J. L. 1999. Using taxonomy to predict success among introduced avifauna: relative importance of transport and establishment. Conser. Biol. 13: 560-567.

Mack, R.N., Simberloff, D., Lonsdale, W.M., Evans, H., Clout, M., Bazzaz, F.A. 2000. Biotic invasions: causes, epidemiology, global consequences, and control. Ecological Applications 10 (3): 689-710.

Manchester, S. J. \& Bullock, J. M. 2000. The impacts of non-native species on UK biodiversity and the effectiveness of control. Journal of Applied Ecology 37: 845864.

Manor, R. \& Saltz, D. 2004. The impact of free-roaming dogs on gazelle kid/female ratio in a fragmented area. Biological Conservation, 119: 231-236.

Marinho-Filho, J.S., Rodrigues, F.H.G., Guimarães, M.M. 1998. Mamíferos da Estação Ecológica de Águas Emendadas. 34-63. In: Marinho-Filho, J.S., F.H.G. Rodrigues \& M.M. Guimarães (Eds) Vertebrados da Estação Ecológica de Águas Emendadas. SEMATEC/IEMA, Brasília, Brasil.

McGeoch, M.A., Butchart, S.H.M., Spear, D., Marais, E., Kleynhans, E. J., Symes, A., Chanson, J., Hoffmann, M. 2010. Global indicators of biological invasion: species numbers, biodiversity impact and policy responses. Diversity and Distributions 16: 95-108.

McKinney, M.L. \& Lockwood, J.L. 1999. Biotic homogenization: a few winners replacing many losers in the next mass extinction. Trends in Ecology and Evolution 14: $450-453$.

Meyerson, L.A. \& Mooney, H.A. 2007. Invasive alien species in an era of globalization. Front. Ecol. Environ. 5(4): 199-208.

Miklósi, Á. 2007. Dog behaviour, evolution, and cognition. Oxford University Press, Oxford. 289p.

MMA (Ministério do Meio Ambiente do Brasil). 2011. Espécies exóticas invasoras: Situação Brasileira. Brasília, Brasil. 28p.

Monteiro-Filho, E.L.A., 1995. Os Mamíferos da Santa Genebra. In. Morellato, L.P.C. \& H.F. Leitão-Filho (Eds). Ecologia de Preservação de uma Floresta Tropical Urbana Reserva de Santa Genebra. Campinas, SP. p 86-92.

Mooney, H.A. \& Hobbs, R.J. 2000. Invasive species in a changing world. Island Press. Washington, DC. 
Moore, G.E. 2005. Apresentação da edição original. In: Galindo-Leal C., Câmara I. de G.(Eds). Mata Atlântica: biodiversidade, ameaças e perspectivas. Fundação SOS Mata Atlântica, São Paulo; Conservação Internacional, Belo Horizonte.

Morey, D.F. 2010. Dogs: Domestication and the Development of a Social Bond. Cambridge University Press, Cambridge.

Mukherjee, S. \& Sharma, C. 2001. Prey selection by leopard Panthera pardus in Majhatal Harsang Wildlife Sanctuary, Western Himalaya. Journal of the Bombay Natural History Society 98: 267-268.

Negrão, M. de F. F. \& Valladares-Pádua, C. 2006. Registros de mamíferos de maior porte na Reserva Florestal do Morro Grande, São Paulo. Biota Neotropica 6.

Newsome, A. E. \& Noble, I. R. 1986. Ecological and physiological characters of invading species. In: Groves, R.H. \& Burdon, J.J. (Eds). Ecology of Biological Invasions. Cambridge University Press, Cambridge, England. p 1-20.

Oldroyd, B.P. 1999. Coevolution while you wait: Varroa jacobsoni, a new parasite of western honeybees. Trends in Ecology and Evolution 14: 312-315.

Oliveira, V. B. de, Linares, A. M., Corrêa, G. L. C., Chiarello, A. G. 2008. Predation on the black capuchin monkey Cebus nigritus (Primates: Cebidae) by domestic dogs Canis lupus familiaris (Carnivora: Canidae), in the Parque Estadual Serra do Brigadeiro, Minas Gerais, Brazil. Revista Brasileira de Zoologia 25 (2): 376-378

Ortega-Pacheco, A., Rodriguez-Buenfil, J.C., Bolio-Gonzales, M.E., Sauri-Arcco, C.H., Jiménez-Coelho, M., Forsberg, C.L. 2007. A survey of dog populations in urban and rural areas of Yucatan, Mexico. Anthrozoos 20 (3): 261-274.

Packer, C., Altizer, S., Appel, M., Brown, E., Martrenson, J., O’Brien, S.J., RoelkeParker, M., Hofmann-Lehmann, R., Lutz, H. 1999. Viruses of the Serengeti: patterns of infection and mortality in African lions. Journal of Animal Ecology 68: 1161-1178.

Pal, S.K., Gosh, B., Roy, S. 1998. Dispersal behavior of free-ranging dogs (Canis familiaris) in relation to age, sex, season and dispersal distance. Applied Animal Behavior Science 61: 123-132.

Pimentel, D., Lach, L., Zuniga, R., Morrison, D. 2000. Costs of nonindigenous species in the United States. BioScience 50(1): 53-65.

Pullin, A.S. 2002. Conservation Biology. Cambridge University press, New York.

Pyare, S. \& Berger, J. 2003. Beyond demography and delisting: ecological recovery for Yellowstone's grizzly bears and wolves. Biol. Conserv. 113:63-73. 
Rahel, F.J. 2000. Homogenization of fish faunas across the United States. Science 288: 854-856.

Raizada, P., Raghubanshi, A.S., Singh, J.S. 2008. Impact of invasive alien plant species on soil processes: a review. Proceedings of the National Academy of Sciences India, Section B, Biological Sciences 78: 288-298.

Randall, D.A., Marino, J., Haydon, D.T., Sillero-Zubiri, C., Knobel, D.L., Tallents, L.A., Macdonald, D.W., Laurenson, M.K. 2006. An integrated disease management strategy for the control of rabies in Ethiopian wolves. Biological Conservation 131: $151-162$.

Rejmanek, M. \& Richardson, D.M. 1996. What attributes make some plant species more invasive? Ecology 77: 1655-1661.

Ribeiro, M. C., Merzger, J. P., Maetensen, A.C., Ponzoni,F. J., Hirota, M.M. 2009. Brazilian Atlantic Forest: how much is left and how the remaining Forest is distributed? Implications for conservation. Biol. Conserv. 142: 1141-1153.

Rodrigues, F.H.G. 2002. Ecologia do lobo guará na Estação Ecológica de Águas Emendadas, DF. Dissertação de Doutorado em Ecologia, Instituto de Biologia, Universidade Estadual de Campinas, Campinas, Brasil.

Rodríguez. J. P. 2001. Exotic species introductions into South America: an underestimated threat? Biodiversity and Conservation 10: 1983-1996.

Roelkee-Parker, M.E., Munson, L., Packer, C., Kock, R., Cleaveland, S., Carpenter, M., O’Brien, S.J., Pospischil, A., Hoffman- Lehmann, R., Lutz, H. 1996. A canine distemper virus epidemic in Serengeti lions (Panthera leo). Nature 379: 441-445.

Ruiz, G.M. \& Carlton, J.T. 2003. Invasion vectors: a conceptual framework for management. In: Ruiz, G.M. \& Carlton, J. T. (Eds) Invasive species: vectors and management strategies, Island Press, Washington, DC. p. 459-504.

Savolainen, P., Zhang, Y., Luo, J., Lundeberg, J., Leitner, T. 2002. Genetic evidence for an east Asian origin of domestic dogs. Science 298: 1610-1613.

Sher, A.A. \& Hyatt, L.A. 1999. The disturbed resource-flux invasion matrix: a new framework for patterns of plant invasion. Biol Invas 1: 107-14.

Sillero-Zubiri, C., King, A.A., MacDonald, D.W. 1996. Rabies and mortality in Ethiopian wolves (Canis simensis). Journal of Wildlife Diseases 32: 80-86.

Sillero-Zubiri, C. \& Macdonald, D.W. 1997. The Ethiopian Wolf: Status Survey and Conservation Action Plan. IUCN Canid Specialist Group, Gland, Switzerland, and Cambridge, UK. 
Singh, U.S., Singh, R., Satyanarayan, K., Sheshamani, G., Kottur, S. 2007. Ecology of Big Carnivores and Conflict Studies in Sanapur Community Reserve. Wildlife SOS, New Delhi, India.

Smallwood, K.S. 1994. Site invasibility by exotic birds and mammals. Biological Conservation 69: 251-259.

Srbek-Araujo A. C., Chiarello A. G. 2005. Is camera-trapping an efficient method for surveying mammals in Neotropical forests? A case study in south-eastern Brazil. Journal of Tropical Ecology 21: 121-125.

Srbek-Araujo A. C., Chiarello A. G. 2008. Domestic dogs in Atlantic forest preserves of south-eastern Brazil: a camera-trapping study on patterns of entrance and site occupancy rates. Brazilian Journal of Biology 68 (4): 771-779.

Temple, S. A. 1992. Exotic birds: a growing problem with no easy solution. Auk 109: 395-397.

Torres, P.C. 2008. Ocorrência de cães domésticos (Canis familiaris) em fragmentos de Mata Atlântica em zona rural e urbana e sua relação com a ocupação humana no entorno. Dissertação de Mestrado, Universidade Estadual de Campinas, Campinas, SP, Brasil.

Torres, P. T. \& Prado, P. I. 2010. Domestic Dogs in a Fragmented Landscape in the Brazilian Atlantic Forest: Abundance, Habitat use and Caring by Owners. Brazilian Journal of Biology.

Usher, M.B., Kruger, F.J., MacDonald, I.A.W., Loope, L.L. \& Brockie, R.E. 1988. The ecology of biological invasions into nature reserves - an introduction. Biological Conservation 44: 1-8.

Van de Bildt, M.W.G., Kuiken, T., Visee, A.M., Lema, S., Fitzjohn, T.R., Osterhaus, A.D.M.E. 2002. Distemper outbreak and its effect on African wild dog conservation. Emerging Infectious Diseases 8 (2): 211-213.

Vanak, A. T. \& Gompper, M. E. 2009a. Dogs Canis familiaris as carnivores: their role and function in intraguild competition. Mammal Rev. 39(4): 265-283.

Vanak, A.T. \& Gompper, M.E. 2009b. Dietary niche separation between sympatric freeranging domestic dogs and Indian foxes in central India. Journal of Mammalogy, 90 (5): 1058-1065.

Vanak, A. T. \& Gompper, M. E. 2010. Interference competition at the landscape level: the effect of free-ranging dogs on a native mesocarnivore. Journal of Applied Ecology, 47: 1225-1232. 
Vitousek, P.M., D’Antonio, C.M., Loope, L.L., Rejmánek, M., Westbrooks, R. 1997. Introduced species: a significant component of human-caused global change. New Zealand Journal of Ecology 21: 1-16.

Wandeler, A.I., Matter, H.C., Kappeler, A., Budde, A. 1993. The ecology of canine rabies: a selective review. Rev. Sci. Tech. Off Int. Epiz. 12: 51-71.

Wattaola, G., Allan, J.R., Feare, C.J. 1996. Problems and management of naturalised introduced Canada geese Branta canadensis in Britain. In: Holmes, J.S. \& Simons, J.R. (Eds) The Introduction and Naturalisation of Birds, HMSO, London, UK. p. 71-78.

Webb, D.A. 1985. What are the criteria for presuming native status? Watsonia 15: 231236.

Whitby, J.E., Johnstone, P., Sillero-Zubiri, C. 1997. Rabies virus in the decomposed brain of an Ethiopian wolf detected by nested reverse transcription-polymerase chain reaction. Journal of Wildlife Diseases 33:912-915.

Whiteman, C., Matushima, E., Cavalcanti Confalonieri, U., Palha, M., da Silva, A., Monteiro, V. 2007. Human and domestic animal populations as a potential threat to wild carnivore conservation in a fragmented landscape from the Eastern Brazilian Amazon. Biological Conservation 138: 290-296.

Williamson, M. 1992. Environmental risk from the release of genetically modified organisms (GMOs) - the need for molecular ecology. Molecular Ecology 1: 3-8.

Williamson, M. 1993. Invaders, weeds and the risk from genetically manipulated organisms. Experenti, 49: 219-224.

Williamson, M . 1996. Biological Invasions. Chapman \& Hall, London, UK.

Williamson, M. \& Fitter, A. 1996. The characters of successful invaders. Biological Conservation 78: 163-170. 


\section{Capítulo 1}

Domestic dog invasion in Atlantic forest fragmented

landscapes 


\title{
Domestic dog invasion in Atlantic forest fragmented landscapes
}

\author{
Enrico Frigeri ${ }^{1}$, Karina D. Espartosa ${ }^{2}$, Gustavo de Oliveira ${ }^{2}$ and Renata Pardini ${ }^{1}$ \\ ${ }^{1}$ Departamento de Zoologia, Instituto de Biociências, Universidade de São Paulo, Rua \\ do Matão, travessa 14, 101, CEP 05508-090, São Paulo, SP, Brazil \\ 2 Departamento de Ecologia, Instituto de Biociências, Universidade de São Paulo, Rua \\ do Matão, travessa 14, 101, CEP 05508-090, São Paulo, SP, Brazil
}

\begin{abstract}
Although the role of biological invasions in the biodiversity crises has been recognized, most studies on this subject address relatively small spatial scales, focus on few factors simultaneously or target conservation units. Drawing on an extensive dataset obtained in two rural landscapes of one of the main biodiversity hotspots, we focus on the causes and consequences of the invasion by domestic dogs, one of the most common exotic species worldwide. Through a standardized camera trap protocol across 48 forest fragments, the identification of individual dogs, and information obtained by interviewing their owners, we: (1) describe the management and the characteristics of dogs that visit forest fragments, (2) compare, between landscapes with different proportions of remaining forest (10\% and 50\%), the frequency and time of visits, the size of groups of invading dogs, and the environmental drivers of the invasion, and (3) investigate the impacts of invasion on the distribution of native mammals. Our findings highlight that the invasion of domestic dogs is among the main threats to native mammals in human-modified, tropical landscapes: (1) access to forest was facilitated both by the predominant type of management (dogs kept free) and deforestation, (2) the number of dogs that visit fragments was very high, and one third of those was not vaccinated, and (3) the invasion by dogs negatively affected the distribution of a larger number of native mammals than the loss of $40 \%$ of forest in the landscape. Finally, landscape characteristics were more important than propagule pressure to explain the intensity of invasion, and should thus not be overlook when planning actions to mitigate the impacts of dogs.
\end{abstract}

Key-words: abundance models, alien species, Canis familiaris, habitat fragmentation, habitat quality, invasive species 


\section{Resumo}

Embora o papel de invasões biológicas na crise da biodiversidade tenha sido reconhecido, a grande maioria dos estudos aborda escalas espaciais relativamente pequenas, enfoca poucos fatores simultaneamente e foram realizados em unidades de conservação. A partir de um extenso banco de dados obtido em duas paisagens rurais de um dos principais hotspots de biodiversidade, pretendemos contribuir com o entendimento das causas e consequências da invasão por cães domésticos, uma das espécies exóticas mais comuns no mundo. Através da amostragem padronizada com câmeras fotográficas em 48 fragmentos florestais, da identificação individual dos cães e de informações obtidas por entrevistas com seus proprietários, nós: (1) descrevemos o tipo de manejo e as características dos cães que visitam fragmentos florestais, (2) comparamos, entre paisagens com diferentes proporções de floresta remanescente (10 e $50 \%$ ), a frequência e horário de visitas e o tamanho de grupos de cães invasores assim como os fatores determinantes da intensidade de invasão, e (3) investigamos o impacto da intensidade de invasão sobre a distribuição de mamíferos silvestres de maior porte. Este trabalho indica, por mais de uma fonte de informação, que a invasão de cachorros domésticos pode estar entre as principais ameaças à fauna em paisagens tropicais modificadas pelo homem: (1) o acesso dos cães a áreas de vegetação é facilitado tanto pelo tipo de manejo dos cães (que são mantidos soltos) quanto pelo desmatamento, (2) o número de cães que visitam fragmentos foi muito alto, e um terço deles não foi vacinado e (3) a invasão por cães afeta negativamente a distribuição de um maior número de espécies de mamíferos nativos do que a perda de $40 \%$ de floresta na paisagem. Por fim, características da paisagem foram mais importantes do que a pressão de propágulos para explicar a intensidade da invasão, e deveriam ser consideradas no planejamento de ações que visem mitigar o impacto dos cães.

Palavras-chave: modelos de abundância, espécies invasoras, Canis familiaris, fragmentação de habitat, qualidade do habitat, espécies exóticas

\section{Introduction}

Biological invasions have been increasing worldwide (Hulme, 2009; McGeoch et al., 2010) and are presently considered the second most important threat to biodiversity (Vitousek et al., 1997, Baillie et al., 2004). Through competition, predation, herbivory, hybridization, and pathogen transmission, invading species can change the behavior of individuals, such as the period of activity or vigilance levels (Altendorf et 
al., 2001; Pyare and Berger, 2003; Creel and Christianson, 2008), decrease species abundance and richness (Wattaola et al., 1996; Oldroyd,1999; Blackburn et al., 2004; Gaertner., 2009), altering the structure of native communities (Hejda et al., 2009), modify the genetic diversity of their populations (Ellstrand and Schierenbeck, 2000), or affect ecosystem processes, such as nutrient cycling (Ehrenfeld, 2003; Raizada et al.,2008).

Among the potentially invading exotic species, the most common and widely distributed is perhaps the domestic dog that was introduced wherever man has settled (Wandeler et al., 1993; Pimentel et al., 2000) for property protection, livestock management, company and hunting (Hart, 2008; Khan, 2009). It is today the most abundant carnivore in the world (Vanak and Gompper, 2010), with a population estimated at 700 million individuals (Hughes and Macdonald, 2013). Although the success of human population expansion around the globe is partly linked to dog domestication (Miklósi, 2007; Clutton-Brock, 2008; Morey, 2010), we presently know that these animals disturb and modify native ecosystems (Clout, 1995), affecting wildlife populations through ecological interactions such as competition and predation and as pathogen reservoirs (Young et al., 2011; Vanak and Gompper, 2009b). Although the underlying mechanism is often unknown, negative relationships between domestic dog populations and those of wildlife species have been observed (Lenth et al., 2008; Lacerda et al., 2009). In some cases, however, the mechanisms were identified, and domestic dogs have been implicated in drastic population reductions, either through pathogen transmission to carnivores (Kennedy et al., 2000; Cleaveland et al., 2000; Van de Bildt et al., 2002; Randall et al., 2006) or through predation to ungulate (Manor and Saltz, 2004).

Given that domestic dogs are important to human populations, but represent a threat to native fauna, information on management and population size, ecological and behavioral traits such as exploratory behavior, habitat use and movements, factors that determine the frequency of visits to native vegetation, and impacts on wildlife, are essential to guide the adequate management of this species. However, most available information presently comes from occasional and sporadic observations (Young et al., 2011), concerning relatively small spatial scales, targeting mainly conservation units and their surroundings (Hughes and Macdonald, 2013), overlooking the rural landscapes that today encompass most forest remnants in the tropics. 
Accumulated evidence indicates that in rural regions domestic dogs are not kept confined (Butler et al., 2004; Campos et al., 2007; Ortega-Pacheco et al., 2007), reach high population growth rates (Kitala et al., 2001) and do not receive supervision or veterinarian care (Butler and Bingham, 2000; Torres, 2008). Although dogs can move up to $30 \mathrm{~km}$ in just 25 hours and present home ranges of up to 2451 ha (Meek, 1999), dog movement varies according to the type of environment, animal size and type of management (Rubin and Beck, 1982). Visits to native environments are usually made by isolated individuals or small groups (Beck, 2002; Paschoal et al., 2012). Nearby villages and households are the main source of dogs that penetrate into native vegetation (Fiorello et al., 2006 Whiteman et al., 2007), where frequency of visits is higher at the edges (Srbek-Araujo and Chiarello, 2008; Lacerda et al., 2009). As for other invasive species for which the propagule pressure is one of the main drivers of invasion intensity (Lockwood et al., 2005, Gurevitch et al., 2011), some studies indicate that the number of dogs raised in the surroundings influences the occurrence of these animals in native habitat, and that the frequency of visits is higher in more fragmented areas or in areas with greater human population density (Odell and Knight, 2001; Lacerda, 2009). However, studies usually focus on a few potential drivers simultaneously.

In the neotropics the Atlantic Forest is probably one of the most suitable areas for studying domestic dog invasion. Presently, most of the Brazilian population lives in areas that were originally covered by this forest, reduced to less than $16 \%$ of its original cover (Ribeiro et al., 2009). Most remnants (99.5\%) are smaller than 1000 ha (Ribeiro et al., 2009) and harbor impoverished and simplified mammal communities (Chiarello, 1999, et al., Cassano et al. 2012). Thus, intense habitat fragmentation and disturbance, high density of both humans as well as domesticated animals and the impoverishment of native fauna make the Atlantic Forest remnants vulnerable to invasion by domestic dogs.

Drawing on an extensive dataset obtained in two rural landscapes with different proportions of remaining Atlantic Forest, our aim is to contribute to the understanding of the causes and consequences of domestic dog invasion in one of the main biodiversity hotspots. We first describe the type of management and the characteristics of dogs that visit forest fragments. We then compare the characteristics of the invasion in terms of the frequency and time of the visits and the size of groups between landscapes with different proportions of remaining forest. We also investigate the relative importance of local-scale drivers, such as the quantity and quality of forests and 
the number of dogs raised in the surroundings, and their interactions with the quantity of forest at the landscape scale, to determine invasion intensity. Finally, we evaluate the impacts of invasion intensity, and its interaction with the quantity of forest at the landscape scale, on the distribution of native mammals.

\section{Methods}

\section{Study areas}

The study areas consist of two rural landscapes of 10000 ha both situated on the Atlantic Plateau of São Paulo, in the municipalities of Ribeirão Grande and Capão Bonito, and of Tapiraí and Piedade. The entire region was originally covered by Atlantic Forest, classified as "Lower Montane Atlantic Forest" (Oliveira-Filho and Fontes, 2000), which is currently reduced to forest fragments in mid-stage of regeneration. Altitude varies from 800 to $1100 \mathrm{~m}$ above sea level, annual rainfall from $1362 \mathrm{~mm}$ to $1807 \mathrm{~mm}$, and mean annual temperature is $19^{\circ} \mathrm{C}$ (with mean maximum $27^{\circ}$ $\mathrm{C}$ and mean minimum $9^{\circ} \mathrm{C}$ ) (CPTEC, 2005; CEPAGRI, 2009).

Despite the similarity regarding climate, topography, vegetation type and human use (Pardini et al., 2010), the proportion of remaining forest differs between the two landscapes. The Ribeirão Grande/ Capão Bonito landscape is composed, mostly, of open, anthropogenic areas, mainly pastures (44\%) and annual crops (31\%), with only $11 \%$ of remaining forest. The Tapiraí/ Piedade landscape, on the other hand, comprises $51 \%$ of open anthropogenic areas, also dominated by pastures (24\%) and annual crops (13\%), with $49 \%$ of remaining forest (Figure S1).

Mammal communities in forest remnants of both landscapes are simplified, dominated by medium-sized species, mainly opossums (Didelphis albiventris and Didelphis aurita), armadillos, (Dasypus novemcinctus, Euphractus sexcinctus and Cabassous sp.) and medium-sized carnivores (Eira barbara, Procyon cancrivorus, Nasua nasua, Cerdocyon thous, Leopardus spp.). Some larger species, such as the capybara (Hydrochoerus hydrochaeris), the deer (Mazama spp.) and the puma (Puma concolor) are rare, and others were not recorded in any of the landscapes (Panthera onca, Tapirus terrestris, Tayassu pecari and Pecari tajacu) (Oliveira, 2011; Espartosa et al. 2011).

\section{Sampling design}

In each of the landscapes, we sampled 24 forest fragments, chosen to maximize the variation in the quantity of forest in the surroundings. In the most deforested 
landscape, due to the low quantity of remaining forest, the 24 largest fragments were selected (varying from $5 \%$ to $36 \%$ of forest in the surroundings, Figure S1b). In the more forested landscape, the selected fragments varied from $18 \%$ to $77 \%$ of forest in the surroundings (Figure S1c). In both landscapes, minimum distance between sampling sites was $900 \mathrm{~m}$.

\section{Data collection}

\section{Recording domestic dogs and native mammals in forest fragments}

In each of the 48 forest fragments we installed three camera traps, $100 \mathrm{~m}$ apart from each other (largest possible distance, given the size of the smallest fragment) and placed at $20 \mathrm{~cm}$ above forest ground. The lateral sets of cameras were baited with banana, corn and salt and the central camera with sardines or scent lures - Pipi Dog (www.coveli.com.br) and liquid Catnip Brasileiro (www.catnipbrasileiro.com.br). In each landscape, we carried out three 1-month sampling sessions. In each of them, the cameras in all 24 fragments were active for 10 or 15 days, with 12 fragments sampled simultaneously. In the more deforested landscape, the three sampling sessions occurred from February to October 2009 and in the more forested landscape from October to July 2007. Due to problems with camera traps, sampling effort varied from 103 to 135 camera-days across fragments in the more deforested landscape, and from 90 to 135 camera-days across fragments in the more forested landscape, totaling, respectively, 3095 and 2670 camera-days in each landscape.

Type of management and characteristics of dogs that visit forest fragments

The dogs recorded in the photographs were identified from characteristics such as fur color, sex, size, breed, and scars. At the beginning of 2012, two years after recording the dogs with camera traps, we visited the households located within a radius of $800 \mathrm{~m}$ around the sampling sites of the more deforested landscape (Figure S1b), aiming to identify where the dogs in the photographs were raised. The photographs were used in interviews with land owners to identify if any of the dogs was raised there. Interviews also included a questionnaire with open and closed questions (multiple choice) to obtain information on the age and sex of the dog, the type of management (confinement, feeding, vaccination and sterilization), the frequency of visits by dogs to forest fragments, and the animals hunted by dogs (Appendix S1).

In the more forested landscape, because of the long time elapsed after data collection with camera traps (approximately five years), most recorded dogs had already 
died or the places where they were raised were not identified. We thus did not use this data.

Drivers of invasion by domestic dogs

Number of dogs raised in the surroundings - In both landscapes during data collection with camera traps the number of domestic dogs in the surroundings of all 48 sampled fragments was obtained through interviews with all residents (heads of households) located within a 800-m radius circumference around sampling sites.

Quantity and quality of forests in the surroundings - These data were obtained from land use maps of 1962, 1980, and 2005 (Lira et al., 2012). Through the superposition of these maps, native forest remnants were categorized into classes of regeneration age: (1) forests older than 43 years (already present in 1962), forests between 25 and 43 years (absent in 1962 but present in 1980) and (3) forests younger than 25 years (present only in 2005) (Figure S1). Using Arc Map (ESRI ${ }^{\circledR} \operatorname{ArcMap}^{\mathrm{TM}}$ 9.2.) we calculated the total quantity of forest (forest quantity) and the proportion of older forests (older than 43, forest quality) within a 800-m radius circumference around sampling sites.

Quantity of forest at the landscape scale - This is a categorical variable considering the percentage of remaining forest at the landscape: more $(\sim 10 \%)$ and less deforested ( 50\%) landscapes.

\section{Data analysis}

Type of management and characteristics of dogs that visit forest fragments

With the information collected through the questionnaire (Appendix S1), we calculated the percentage of dogs that were vaccinated, sterilized and kept under different types of management among those that were recorded in fragments of the more deforested landscape. We also identified the native mammals more frequently preyed on by these dogs, according to the owners' opinion.

Using Arc Map 9.2 (ESRI ${ }^{\circledR}$ ArcMap ${ }^{\mathrm{TM}}$ 9.2.), we calculated the linear distance between where dogs were raised and forest sites where they were photographed, a measurement that was used as an estimate of dog movements. To verify if length of movement is influenced by the age or sex of individuals, we constructed and compared through model selection a set of candidate models, which includes a constant model, where length of movement followed a Gaussian distribution with both parameters, mean $(\mu)$ and standard deviation $(\delta)$, constant, and two models in which the parameter mean 
$(\mu)$ varied as a linear function of age or sex and standard deviation $(\delta)$ was kept constant.

Also through model selection we verified if the frequency of visits of individuals to the fragments, number of visits per individual excluding sequential records (i.e. pictures taken from the same individual in the same camera within intervals shorter than 1 hour which are likely to occur because dogs stay in front of the camera eating the bait), is influenced by the distance between where dogs were raised and visited fragments. The set of candidate models included a constant model, where the number of visits followed a Poisson distribution with the parameter $(\lambda)$ constant, and another model in which this parameter varied as a log function of the distance between where dogs were raised and visited fragments.

Frequency and time of visits to forest, and group size in landscapes with different proportion of remaining forest

Having identified dogs recorded in the fragments, we calculated for each of them the number of visited fragments and the frequency and time of visits, as well as the size of the groups of dogs recorded together.

We used the Kolgomorov-Smirnov test to compare the proportion of individuals in classes of numbers of visits (i.e. number of records excluding sequential records) between landscapes. We also used the Watson test of homogeneity between two samples (Jammalamadaka and Sen Gupta, 2001) to compare the time of visits between landscapes, and the Rayleigh test (Wilkie, 1983) to test, for each landscape, if visits were uniformly distributed during the day (if not, we estimated the time of greater activity with the Von Mises estimate, Jammalamadaka and Sen Gupta, 2001). For the analyses of time of visits, we considered just one value per individual, excluding the sequential records, and calculating the median of the time of all visits for each individual. Finally, we tested if the frequency of group formation (more than one individual registered together) varied between landscapes using a contingency table and a chi-squared test.

\section{Drivers of invasion by domestic dogs}

We used abundance models (Royle, 2004), modified from occupancy models (Mackenzie et al., 2002), to investigate the relative importance of local-scale drivers (quantity and quality of forest and number of dogs raised in the surroundings), and their interactions with the quantity of forest at the landscape scale, to determine the intensity of the invasion, i.e. the number of domestic dogs that visit forest fragments. These 
models contain two parameters: abundance $(\lambda)$ and probability of detection $(r$, the probability that an individual is detected), estimated from the history of captures of individuals throughout sampling sessions (which in this case were three) (Royle, 2004). Given the small size of the sampling units (3 cameras in a 200-m long transect) relative to the home range area of dogs, we interpreted the abundance $(\lambda)$ as the number of individuals that used forest fragments (McCarthy et al., 2013). The association among the independent variables was tested through Pearson correlations for continuous variables and ANOVAs for continuous variables and the categorical quantity of forest at the landscape scale.

The set of candidate models included a constant model (both parameters $r$ and $\lambda$ constant), a model where detectability ( $r$ ) was modeled as a function of sampling effort ( $\lambda$ constant), and 34 models in which abundance $(\lambda)$ was modeled as a function of the independent variables ( $r$ constant). These included four simple models, each of them containing one of the four independent variables, 11 additive models, containing all possible combinations among the four independent variables, and 19 interaction models that represent combinations that included the independent variable quantity of forests at the landscape scale and its interactions with the other independent variables.

Impact of invasion and its interaction with the quantity of forests at the landscape scale on mammal distribution

We used occupancy models (Mackenzie et al., 2002; Mackenzie et al., 2006) to investigate the effects of the number of invading dogs (estimated through the best abundance model described above), the quantity of forest at the landscape scale and the interaction between these factors on the distribution of mammals. These models contain two parameters: probability of occupancy ( $\Psi)$ and probability of detection or detectability ( $\mathrm{p}$, probability that a species is detected), both estimated from the history of detection of species throughout sampling sessions (in this case, three). Again, given the small size of sampling units relative to the home range area of most mammals, we interpreted the probability of occupancy $(\Psi)$ as the proportion of fragments used by the species (Mackenzie et al., 2006). Detectability (p) was interpreted as a proxy for intensity of use of fragments (Royle and Nichols, 2003). Probability of occupancy ( $\Psi$ ) was modeled for mammal species that occurred in a minimum of six and a maximum of 35 fragments, and detectability (p) for mammal species that occurred in a minimum of 15 fragments, so that for two species only probability of occupancy ( $\Psi)$ was modeled, for two only detectability (p) and for three both parameters (Table S1). We tested the 
association between the number of estimated invading dogs and the quantity of forest at the landscape scale through an ANOVA.

For the species for which both parameters were modeled, the selection of models was divided into three steps (Bailey et al., 2004). Firstly, we maintained the probability of occupancy constant, $\Psi($.$) , and modeled detectability, \mathrm{p}(\mathrm{var})$, as a function of the two independent variables (two simple models, one additive, and one interaction model). Secondly, we maintained detectability constant, $\mathrm{p}($.$) , and modeled probability of$ occupancy, $\Psi($ var), in the same way. In both steps we also used a constant model, $\Psi()$. $\mathrm{p}($.$) , and, in the first one also a model with detectability as a function of sampling effort,$ p(effort). Thirdly, the selected models $\Psi(.) \mathrm{p}($ var) and $\Psi($ var $) \mathrm{p}($.) were combined into models $\Psi$ (var) $\mathrm{p}$ (var) to explore whether the inclusion of co-variables in both parameters improved model performance. For the species for which just one parameter was modeled, only the first or the second step was run.

In all model selection analyses, models were compared through the Akaike Information Criterion corrected for small-samples (AICc) (Burnham and Anderson, 2002), considering that models that present a difference less than or equal to 2 in AICc value relative to the best model $(\triangle \mathrm{AICc})$ are equally plausible (Burnham and Anderson, 2002).

All the analyses were performed in Program R, using packages "bbmle","car", "CircStats", "chron", "MASS", and "Unmarked" (R.2.11.0, The R Foundation for Statistical Computing. 2008, Vienna, Austria).

\section{Results}

Type of management and characteristics of dogs that visit forest fragments

Through the interviews with owners we located 30 of the 51 individuals recorded in the fragments of the more deforested landscape, which were raised in 16 different households (Figure S1b). Nineteen of these were males and 11 females and all of them visited only one fragment. Most of these 30 animals were vaccinated less than one year ago against rabies (70\% or 21 individuals) and against cynomosis and parvovirosis $(66.6 \%$ or 20 individuals), but a minority, just 2 dogs, (6.6\%) were sterilized. The great majority ( $96.6 \%$ or 29 individuals) is kept free both during the day and at night. According to the owners all dogs were fed daily and feeding frequency varied from two to three times a day. Also according to owners, 29 dogs (96.6\%) hunt other animals, the main preys being: porcupines (hunted by 22 individuals or $73 \%$ of 
dogs), opossums (21 individuals or $70 \%$ of dogs), armadillos (15 individuals or $50 \%$ of dogs) and coatis (7 individuals or $23 \%$ of dogs).

Among these 30 individuals, considering the linear distance between where they were raised and visited fragments, length of movement varied from 174 to $1950 \mathrm{~m}$ (X= $689 \mathrm{~m}, \mathrm{SD}=441 \mathrm{~m})$ and age from 3 to 15 years $(\mathrm{X}=6.88, \mathrm{SD}=3.73)$. Age and sex did not influence the length of movement (Figure 1a, 1b, Table S2). Similarly, the linear distance between where they were raised and visited fragments did not affect the number of visits per individual (Figure 1c, Table S3).

Frequency and time of visits to forest, and group size in landscapes with different proportion of remaining forest

In the more deforested landscape, 51 dogs were identified, distributed in 23 (of the 24) fragments, which were visited on average by 2.1 individuals $(\mathrm{SD}=1.4)$, whereas in the more forested landscape 35 dogs were identified, distributed in 17 (of the 24) fragments, which were visited on average by 1.5 individuals $(\mathrm{SD}=1.6)$. In contrast, however, the number of dogs raised in the surroundings of the sampled fragments was much lower in the more deforested landscape (487 compared to 742). Moreover, while in the more deforested landscape four individuals were recorded in more than one fragment (distances between pairs of fragments visited by the same individual: $1104 \mathrm{~m}$, $1324 \mathrm{~m}, 1525 \mathrm{~m}, 3573 \mathrm{~m}, 5327 \mathrm{~m}, 8985 \mathrm{~m})$, in the more forested landscape all individuals were recorded in one fragment only.

Nevertheless, the proportion of individuals in classes of numbers of visits did not differ significantly between landscapes $(D=0.38 ; p=0.75)$; in both landscapes most dogs made only one visit to fragments (Figure S2). Likewise, although the proportion of individuals that go in pairs into the fragments was higher in the more forested landscape, there was not a significant association between group formation and the quantity of forest at the landscape scale $\left(\chi^{2}=0.38 ; p=0.53\right)$ (Table S4) and in neither landscape a group larger than two individuals was recorded.

Yet the time dogs visited the fragments differed between landscapes (the Watson test of homogeneity: $p=0.04)$. Whereas in the more deforested landscape time of visits was not homogeneously distributed throughout the day (Rayleigh test: $\mathrm{p}<0.001$ ), with a peak around $12: 53 \mathrm{~h}$, in the more forested landscape time of visits was uniformly distributed during the day (Rayleigh Test: $\mathrm{p}=0.07$ ) (Figure S3).

Drivers of invasion by domestic dogs 
The local-scale independent variables were not correlated among themselves, but the quantity of forest at the landscape scale was strongly associated with both forest quantity and quality in the surroundings, as expected (Table S5).

Two models were selected as most plausible to describe the number of dogs that visit forest fragments (Table S6). Both contain as a co-variable of the abundance parameter $(\lambda)$ the quantity of forests in the surroundings, and indicate that the higher the quantity of forests in the surroundings, the lower the number of invading dogs (Figure 2). Besides this co-variable, the second selected model also contains the quality of forests in the surroundings, the quantity of forests at the landscape scale and the interaction between these two variables, indicating that the better the quality of forests or the greater the quantity of forests at the landscape scale, the lower the number of dogs that visit fragments, and that in the more deforested landscape the influence of the quality of forest on the number of dogs is stronger. Among the other four simple models (including the one with sampling effort), only the one that contains the quantity of forest at the landscape scale, which is correlated with the quantity of forest in the surroundings, also presented AICc smaller than the constant model.

Apart from the selected models, another nine models were also more plausible than the constant model, all of them containing the co-variable quantity of forests in the surroundings (Table S6). Some of these models contain, besides the co-variables present in the selected models, the number of dogs raised in the surroundings and the interaction between the quantity of forests in the surroundings and the quantity of forests at the landscape scale, indicating that the higher the number of dogs raised in the surroundings, the higher the number of invading dogs and that in the more deforested landscape the influence of the quantity of forest in the surrounding is stronger.

The number of invading dogs estimated through the best model (simple model that contains only the quantity of forest in the surroundings) varied from 6 to 11 individuals $(\mathrm{X}=8.6$ and $\mathrm{SD}=1.49)$ across fragments of the more deforested landscape and from 2 to $8(X=5.2$ and $\mathrm{SD}=2.00)$ across fragments of the more forested landscape (detectability $=0.109$ ). Thus the estimated number of dogs that use the set of fragments in each landscapes is 208 and 126 dogs, respectively.

Impact of invasion and its interaction with the quantity of forests at the landscape scale on mammal distribution

A total of 16 species of native mammals were recorded, of which only the opossum (Didelphis aurita) occurred in all 48 fragments (Table S1). It was possible to 
build occupancy models for seven of these species: we modeled the probability of occupancy for the deer (Mazama spp.) and small spotted cats (Leopardus spp.), detectability for the opossum (Didelphis aurita) and the nine-banded armadillo (Dasypus novemcinctus), and both parameters for the tayra (Eira barbara), the coati (Nasua nasua) and the crab-eating fox (Cerdocyon thous) (Table S1). The estimated number of invading dogs, as expected, was strongly associated with the quantity of forest at the landscape scale $(\mathrm{F}=44.8$ and $\mathrm{p}=0.0001)$.

The constant model was among the selected models for both species for which we modeled only occupancy, Leopardus spp. and Mazama spp. (Figure 3 and Table S7). For Leopardus spp. the constant model was the only selected, indicating that none of the factors is important for the distribution of this species. Yet for Mazama spp. two simple models were ranked before the constant: the model that contains the estimated number of invading dogs, with a negative effect, is the first-ranked one, followed by the model contains the quantity of forest at the landscape scale, with a positive effect. The additive model containing both variables is also among the selected models, but after the constant model. For this species, the number of invading dogs explains the distribution better than the quantity of forest at the landscape scale.

Among the species for which both parameters were modeled, the models selected indicate, such as for Mazama spp., that both Cerdocyon thous and Eira barbara are negatively affected by the estimated number of invading dogs and positively affected by the quantity of forest at the landscape scale (Figure 3 and Table S7). For $E$. barbara, four models were selected, and three of them, including the two first-ranked, contain the estimated number of invading dogs (either as co-variable of occupancy or detectability, in simple or additive models), indicating again that this variable explains better the distribution of the species. In contrast, for $C$. thous three models were selected, the first-ranked being the one that contains only the quantity of forest at the landscape scale as a co-variable of detectability, the second one an additive model with detectability as a function of both variables, and the third one also contains both variables, the quantity of forests at the landscape scale as co-variable of occupancy and the estimated number of invading dogs as a co-variable of detectability. In this case, the positive effect of quantity of forest at the landscape scale explain better the distribution of the species than the negative effect of the number of invading dogs. For Nasua nasua, the only selected model is additive and indicates that detectability is influenced 
negatively not only by the estimated number of invading dogs, but also by the quantity of forest at the landscape scale (Figure 3 and Table S7).

For both species for which we modeled only detectability, Dasypus novemcinctus and Didelphis aurita, the selected models, such as for N. nasua, also indicate a negative effect of the quantity of forest at the landscape scale (Figure 3 and Table S7). For D. novemcinctus two simple models were selected, the first-ranked being the one that contains the number of invading dogs, but in this case with a positive effect. For $D$. aurita, however, two models were selected, the first-ranked is a simple model, with a negative effect of the quantity of forest at the landscape scale, and the secondranked is an additive model, which also includes the negative effect of the estimated number of invading dogs.

The models that consider the interaction between independent variables were not selected for any species. However, additive models were selected for six of the seven species (Table S7), indicating that although the number of invading dogs is highly correlated with the quantity of forest at the landscape scale, the inclusion of this factor considerably increases the explanatory power of these models.

\section{Discussion}

Type of management and characteristics of dogs that visit forest fragments

All owners manage their dogs in an inappropriate way in at least one aspect with respect to the prevention of impacts on the already simplified mammal fauna of Atlantic forest remnants. Firstly, it is of particular concern that about one third of the dogs were not vaccinated in the past year, suggesting that transmission of diseases can be a significant threat to native fauna (Cleaveland et al., 2000; Kitala et al., 2001; Van de Bildt et al., 2002; Randall et al., 2006).

Secondly, the great majority of dogs is not sterilized and is kept free, which probably favors mating, makes it difficult to control breeding and contributes to the high population density observed in this and in other studies in rural landscapes (Kitala et al., 2001; Vanak and Gompper, 2010). Another aspect of management that favors high population densities is human subsidies, mainly through feeding (Butler and du Toit, 2002; Vanak and Gompper, 2009a). Indeed, all dogs were fed on a daily basis.

Thirdly, even frequently fed, most dogs were kept free, favoring visits to forest fragments, and these visits lead to preying native mammals. Although feeding can decrease predation (Butler and du Toit, 2002; Silva-Rodriguez and Sieving, 2011), 
hunting is an instinctive behavior of dogs (Thorne, 2008; Crooks and Soulé, 1999; Savolainen et al., 2002; Koster and Tankersley, 2012), which is often stimulated by owners through rewards (Noss and Cuellar, 2001; Fiorello et al.; 2006; Whiteman et al., 2007). Even though dogs are not considered efficient predators (Anderson, 1986; Van't Woudt, 1990; Oliveira and Cavalcanti, 2002), they can cause negative impacts given the high number of individuals that visit fragments (Manor and Saltz, 2004; Young et al., 2011). Apparently impact through predation occurs mainly on the most common species, the most hunted animals being also (excepting the porcupine whose predation is much more easily detected) the most common in the landscape. In fact dogs usually present a generalist diet (Thorne, 2008; Koster and Tankersley, 2012).

In contrast to the observed in other studies (Claridge et al. 2009; Robley et al. 2010), sex and age of the dogs did not influence the length of movements. Moreover, the number of visits made per individual to forest fragments was not influenced by the distance from where they are raised to visited fragments. Possibly, the high proportion of open areas in the study landscape and the constant human presence in the fragments allow that dogs reach forest fragments irrespective of sex, age or distance. On the other hand, similarly to what was found in other studies (Fiorello et al; 2006; Whiteman et al.; 2007), most dogs recorded inside the fragments have owners and come from nearby villages and households, suggesting that more appropriate management is particularly important for the dogs that are raised in the surroundings of forest remnants.

Frequency and time of visits to forest, and group size in landscapes with different proportion of remaining forest

The high number of dogs observed and estimated in forest fragments indicates that the intensity of the invasion by domestic dogs is high in Atlantic Forest remnants, which should pose yet another threat to the already simplified fauna of these fragmented landscapes. In fact, simplified communities, without top carnivores, are more susceptible to biological invasions (Lodge, 1993), and areas where domestic dogs can easily act as top predators (Prugh et al. 2009).

In more deforested landscapes, irrespective of the number of dogs raised around remnants (which was indeed lower), we observed a higher number of invading dogs that visit a larger number of fragments and make longer movements, all of which should increase the impacts of invasion. In these more altered landscapes, the high proportion of anthropogenic open habitats, such as pastures and agricultural areas, should facilitate dog movements (May and Norton, 1996; Manor and Saltz, 2004), and access to forest 
fragments. Furthermore, although in both landscapes visits occur mainly during daytime, as observed in other studies (Srbeck-Araujo and Chiarello, 2008; Paschoal et al., 2012), in the more deforested landscape visits are concentrated in the middle of the day, a time that coincides with the period of greater human activity. This result suggests a stronger influence of human activities on the visits of dogs to forest fragments in more deforested landscapes (Serpell, 2008). This high activity of dogs at daytime represents a threat to medium-sized diurnal native mammals, such as the coati ( $N$. nasua) and the tayra (E. barbara) (Costa et al., 2009; Jimenéz et al., 2010), which are among the most abundant in rural deforested landscapes.

On the other hand, in both landscapes the majority of dogs was recorded only once in forest fragments, as observed in other areas of Atlantic Forest (Srbeck-Araujo and Chiarello, 2008). Thus, the high frequency of visits to the fragments is not a result of the frequent entrance by the same individuals, but of the entrance of many different individuals, which certainly increases the possibility of transmission of dog diseases to wild animals.

Finally, we did not record any group larger than two individuals, as observed in other studies (Daniels and Bekoff, 1989; Paschoal 2008; Srbeck-Araujo and Chiarello, 2008). Small groups may be the consequence of the type of management: in both landscapes feeding is provided frequently and is directed only to the animals that live in the household. This type of management does not favor the formation of large groups (Daniels and Bekoff, 1989; Beck, 2002). It is important to stress, however, that the use of camera-traps is not efficient for recording large groups of animals.

\section{Drivers of invasion by domestic dogs}

The quantity of forests in the surroundings was the most important driver of the number of invading dogs irrespective of the number raised in the surroundings. Once again there are indications that the replacement of forests by matrices composed of open habitats favors dog movements (May and Norton, 1996; Manor and Saltz, 2004) and facilitates access to areas of native vegetation for a higher number of individuals. Our results also indicate that the quantity of forest is a better predictor of the intensity of the invasion by domestic dogs at a smaller scale (fragment surroundings) than at the landscape scale, which suggests that restoration actions next to existing remnants is more effective for controlling invasion.

Forest quality, considered together with the quantity of forests in the surroundings and at the landscape scale, also influenced the number of invading dogs, 
which was higher where forests were younger. Although previous studies showed that occurrence of domestic dogs is higher at the edge of remnants (Revilla et al., 2001; Srbek-Araujo and Chiarello, 2008; Lacerda, 2009; Torres and Prado, 2010), our results suggest that vegetation quality, and not only the distance to the edge, determines invasion by dogs. In fact, altered environments are more easily invaded (Newsome and Noble, 1986; Smallwood, 1994), and disturbances, by negatively affecting native populations, are important to facilitate invasion (Cox, 1999; Sher and Hyatt, 1999; Mooney and Hobbs, 2000; Conover, 2002; D'Antonio and Meyerson, 2002). However, the negative effect of forest quality on the number of invading dogs seems to depend on the quantity of forest at the landscape scale, being more important in more deforested landscapes, where the smaller proportion of remaining forest facilitates access to forests of different qualities.

On the other hand, the number of dogs raised in the surroundings, despite having a positive effect on the number of invading dogs, had a smaller explanatory power than the quantity and quality of surrounding forests. This is an innovative result since previous studies consider propagule pressure one of the main determinants of biological invasions (Lockwood et al., 2005; Catford et al., 2009; Gurevitch et al., 2011). This is the first study to compare the importance of propagule pressure to that of other environmental variables and to show that these can be paramount for dog invasion.

Impact of invasion and its interaction with the quantity of forests at the landscape scale on mammal distribution

The distribution of most native mammals in forest fragments depended, jointly, on the quantity of forests at the landscape scale and on the number of invading dogs. However, the effects of the invasion by domestic dogs negatively affected a higher number of species than the loss of $40 \%$ of forests in the landscape. While the decrease in the quantity of forests at the landscape scale had negative effects on three species, the number of invading dogs influenced negatively five species, all of them potential competitors or preys of domestic dogs (Campos et al.,2007; Vanak and Gompper, 2009a; Young et al., 2011). As the intensity of the invasion is higher in more deforested landscapes and in fragments with a smaller quantity of forests in the surroundings, this result indicates that part of the negative effects on native mammals directly attributed in literature to habitat loss (Chiarello, 1999; Crooks, 2002; Michalski and Peres, 2007; Stone et al., 2009) can be indirect, through the invasion by domestic dogs, since most studies disregard the impacts of dogs on the wild fauna. 


\section{Conclusions and implications for conservation}

This study indicates, based on multiple sources of evidence, that invasion of domestic dogs is among the main threats to the fauna in tropical, human-modified landscapes. Firstly, access to forests in those landscapes is facilitated both by the type of human management of dogs, which are raised free, and by deforestation and alteration of the native vegetation. On the other hand, access to forests does not depend on the distance from where the dogs are raised, individual traits such as sex and age, or the number of dogs raised in the surroundings. This suggests that landscape characteristics are more important than the source of propagules to determine the intensity of the invasion by domestic dogs, and that the invasion is higher in more deforested and altered landscapes, irrespective of the size of dog populations around forests. Secondly, the number of dogs that visits forests is very high, and a considerable proportion of them are not vaccinated and hunt native mammals, suggesting that invading dogs may act as important vectors of pathogens and as predators or competitors of native species. Finally, the distribution of a larger number of native mammals is negatively associated with the number of invading dogs than to the quantity of forest at the landscape scale, indeed suggesting that the presence of dogs negatively impacts populations of native species.

Our results highlight that actions to mitigate the impacts of domestic dog invasion should concentrate, on the one hand, on changes in the management of dogs leading to the restriction of their movements and on the expansion of vaccination, and, on the other hand, more on the maintenance and restoration of forests of good quality than on the implementation of programs of demographic control.

\section{Acknowledgments}

We thank A. Pardini for reviewing the English version of the manuscript; and T. Püttker, P.K. Lira, C. de Barros, P. Torres, B.T. Pinotti, C.R. Cassano, M.X. da Silva, T. Kubik, C. Pagotto, J.R. de Luca and P.E. Moraes for help during the work. This work was funded by FAPESP - Fundação de Amparo à Pesquisa do Estado de São Paulo (05/56555-4), CNPq - Conselho Nacional de Desenvolvimento Científico e Tecnológico (135312/2011-6), BMBF - Bundesministerium für Bildung und Forschung (690144/01 6), and Capes - PROEX. EF, KDE and GO had a MSc fellowship from FAPESP (2011/03113-5, 2005/57521-6, 2009/02954-6), and RP a research fellowship from CNPq (Bolsa de Produtividade 306715/2011-2), during the development of this work. 


\section{References}

Anderson, J.R. 1986. Encounters between domestic dogs and free ranging non-human primates. Applied Animal Behaviour Science 15: 71-86.

Altendorf, K.B., Laundre, J.W., Lopez Gonzalez, C.A., Brown, J.S. 2001. Assessing effects of predation risk on foraging behavior of mule deer. Journal of Mammalogy 82: $430-439$.

Bailey, L.L., Simons, T.R., Pollock, K.H. 2004. Estimating site occupancy and species detection probability parameters for terrestrial salamanders. Ecological Applications 14: 692-702.

Baillie J.E.M., Hilton-Taylor C., Stuart S.N. (Eds). 2004. 2004 IUCN Red List of Threatened Species. A Global Species Assessment. IUCN, Gland, Switzerland and Cambridge, UK.

Beck, A.M. 2002. The ecology of stray dogs: a study of free-ranging urban animals. York Press, Baltimore. 98p.

Blackburn, T.M., Cassey, P., Duncan, R.P., Evans, K.L., Gaston, K.J. 2004. Avian extinction and mammalian introductions on oceanic islands. Science 305: 1955 1958.

Burnham, K.P., Anderson, D.R. 2002. Model selection and multimodel inference. A practical information - theoretic approach. Springer, New York.

Butler, J.R.A., Bingham, J. 2000. Demography and dog-human relationships of the dog population in Zimbabwean communal lands. The Veterinary Record 147: 442-446.

Butler, J.R.A., du Toit, J.T. 2002. Diet of free-ranging domestic dogs (Canis familiaris) in rural Zimbabwe: implications for wild scavengers on the periphery of wildlife reserves. Animal Conservation 5: 29-37.

Butler, J.R.A., du Toit, J.T., Bingham, J. 2004. Free-ranging domestic dogs (Canis familiaris) as predators and prey in rural Zimbabwe: threats of competition and disease to large wild carnivores. Biological Conservation 115: 369-378.

Campos, C.B., Esteves, C.F., Ferraz, K.M.P.M.B., Crawshaw, Jr. P.G., Verdade, L.M. 2007. Diet of free-ranging cats and dogs in a suburban and rural environment, southeastern Brazil. Journal of Zoology 273: 14-20.

Cassano, C.R., Barlow, J., Pardini, R. 2012. Large Mammals in an Agroforestry Mosaic in the Brazilian Atlantic Forest. Biotropica 1-8. 
Catford, J.A., Jansson, R., Nilsson, C. 2009. Reducing redundancy in invasion ecology by integrating hypotheses into a single theoretical framework. Diversity and Distribution 15: 22-40.

CEPAGRI, 2009. Disponível em <www.cpa.unicamp.br>, acessado em 4 de janeiro de 2011.

Chiarello, A.G. 1999. Effects of fragmentation of the Atlantic Forest on mammal communities in south-eastern Brazil. Biological Conservation 89: 71-82.

Claridge, A., Mills, D., Hunt, R., Jenkins, D., Bean, J. 2009. Satellite tracking of wild dogs in south-eastern mainland Australian forests: implications for management of a problematic top-order carnivore. Forest Ecology and Management 258: 814-822.

Cleaveland, S., Appel, M.G.J., Chalmers, W.S.K., Chillingworth, C., Kaare, M., Dye, C. 2000. Serological and demographic evidence for domestic dogs as a source of canine distemper virus infection for Serengeti wildlife. Veterinary Microbiology 72: 217-227.

Clout, M. 1995. Introduced species: the greatest threat to biodiversity? Species 24: 3436.

Clutton-Brock, J. 2008. Origins of the dog: domestication and early history. In: Serpell, J. (Ed.). The domestic dog: Its evolution, behaviour, and interactions with people. Cambridge University Press, Cambridge. p 7-20p.

Conover, M. 2002. Resolving human-wildlife conflicts: the science of wildlife damage management. Lewis Publishers, New York. 418p.

Costa, E.M.J., Mauro, R.A., Silva, J.S.V. 2009. Group composition and activity patterns of brown-nosed coatis in savanna fragments, Mato Grosso do Sul, Brazil. Brazilian Journal of Biology 69: 985-991.

Cox, G.W. 1999. Alien species in North America and Hawaii. Island Press, Washington, D.C.

CPTEC, 2005. Disponível em < www.cptec.inpe.br >, acessado em: 3 de agosto de 2010.

Creel, S., Christianson, D. 2008. Relationships between direct predation and risk effects. Tree 23: 194-201.

Crooks, K.R., Soulé, M.E. 1999. Mesopredator release and avifaunal extinctions in a fragmented system. Nature 400: 563-566.

Crooks, K.R. 2002. Relative sensitivities of mammalian carnivores to habitat fragmentation. Conservation Biology 16: 488-502. 
Daniels, T. J., Bekoff, M. 1989. Population and social biology of free ranging dogs, Canis familiaris. Journal of Mammalogy 70: 754-762.

D’Antonio, C.M., Meyerson, L.A. 2002. Exotic plant species as problems and solutions in ecological restoration: a synthesis. Restoration Ecology 10: 703-713.

Ehrenfeld, J. G. 2003. Effects of exotic plant invasions on soil nutrient cycling processes. Ecosystems 6: 503-523.

Ellstrand, N.C., Schierenbeck, K.A. 2000. Hybridization as a stimulus for the evolution of invasiveness in plants? Proceedings of the National Academy of Sciences of the United States of America 97: 7043-7050.

Espartosa, K.D., Pinotti, B.T., Pardini, R. 2011. Performance of camera trapping and track counts for surveying large mammals in rainforest remnants. Biodiversity and Conservation 20: 2815-2829.

ESRI® ArcMap ${ }^{\mathrm{TM}}$ 9.2. Copyright (C) 1999-2006 ESRI Inc. All rights Reserved.

Fiorello, C.V., Noss, A.J., Deem, S.L. 2006. Demography, hunting ecology, and pathogen exposure of domestic dogs in the Isoso of Bolivia. Conservation Biology 20: 762-771.

Gaertner, M., Den Bree, A., Hui, C., Richardson, D.M. 2009. Impacts of alien plant invasions on species richness in Mediterranean-type ecosystems: a meta-analysis. Progress in Physical Geography 33: 319-338.

Gurevitch, J., Fox, G.A., Wardle, G.M., Inderjit, Taub, D. 2011. Emergent insights from the synthesis of conceptual frameworks for biological invasions. Ecology Letters 14: 407-418.

Hart, L. A. 2008. Dogs as human companions: a review of the relationship. In: The domestic dog. Its evolution behaviour, and interactions with people (Ed: J. Serpell). 161-178p. Cambridge University Press, Cambridge.

Hejda, M., Pysek, P., Jarosik, V. 2009. Impact of invasive plants on the species richness, diversity and composition of invaded communities. Journal of Ecology 97: 393-403.

Hughes, J., Macdonald, D.W. 2013. A review of the interactions between free-roaming domestic dogs and wildlife. Biological Conservation 157:341-351.

Hulme, P.E. 2009. Trade, transport and trouble: managing invasive species pathways in an era of globalization. Journal of Applied Ecology 46: 10-18.

Jammalamadaka, S. R., Sen Gupta, A. 2001. Topics in Circular Statistics. World Scientific Press. Singapore. 
Jiménez, C.F., Quintana, H., Pacheco, V., Melton, D., Torrealva, J., Tello, G. 2010. Camera trap survey of medium and large mammals in a montane rainforest of northern Peru. Peruvian Journal of Biology 17: 191-196.

Kennedy, S., Kuiken, T., Jepson, P.D., Deaville, R., Forsyth, M., Barrett, T., Van de Bildt, M.W.G., Osterhaus, A.D.M.E., Eybatov, T., Duck, C., Kydyrmanov, A., Mitrofanov, I., Wilson, S. 2000. Mass die-off of Caspian seals caused by Canine distemper virus. Emerging Infectious Diseases 6: 637-639.

Khan, M. M. 2009. Can domestic dogs save humans from tigers Panthera tigris? Oryx 43: 44-47.

Kitala, P., McDermott, J., Kyule, M., Gathuma, J., Perry, B., Wandeler, A. 2001. Dog ecology and demography information to support the planning of rabies control in Machacos District, Kenya. Acta Tropica 78: 217-230.

Koster, J., Kenneth, B. 2012. Heterogeneity of hunting ability and nutritional status among domestic dogs in lowland Nicaragua. PNAS 109: 463 - 470.

Lacerda, A.C.R., Tomas, W.M., Marinho-Filho, J. 2009. Domestic dogs as an edge effect in the Brasília National Park, Brazil: interactions with native mammals. Animal Conservation 12: 477-487.

Laurance, W.F., Curran, T.J. 2008. Impacts of wind disturbance on fragmented tropical forests: A review and synthesis. Austral Ecology 33: 399-408.

Lenth, B., Knight, R., Brennan, M. E. 2008. The effects of dogs on wildlife communities. Natural Areas Journal 28: 218-227.

Lira, P.K., Tambosi, L.R., Ewers, R.M., Metzger, J.P. 2012. Land-use and land-cover change in Atlantic Forest landscapes. Forest Ecology and Management 278: 80-89.

Lodge, D.M. 1993. Biological invasions: lessons for ecology. Trends in Ecology \& Evolution 8: 133-137.

Lockwood, J.L., Cassey, P., Blackburn, T. 2005. The role of propagule pressure in explaining species invasions. Trends in Ecology and Evolution 20:223-228.

Mackenzie, D.I., Nichols, J.D., Lachman, G.B., Droege, S., Royle, J.A., Langtimm, C.A. 2002. Estimating site occupancy rates when detection probabilities are less than one. Ecology 83: 2248-2255.

Mackenzie, D.I., Nichols, J.D., Royle, J.A., Pollock, K.H., Bailey, L.L., Hines, J.E. 2006. Occupancy Estimation and Modeling: Infering Patterns and Dynamics of Species Occurence, Elsevier, San Diego. 
Manor, R., Saltz, D. 2004. The impact of free-roaming dogs on gazelle kid/female ratio in a fragmented area. Biological Conservation, 119: 231-236.

May, S.A., Norton, T.W. 1996. Influence of fragmentation and disturbance on the potential impact of feral predators on native fauna in Australia forest ecosystems. Wildlife Research 23: 387-400.

McCarthy, M.A., Moore, J.L., Morris, W.K., Parris, K.M., Garrard, G.E., Vesk, P.A., Rumpff, L., Giljohann, K.M., Camac, J.S., Bau, S.S., Friend, T., Harrison, B., Yue, B. 2013. The influence of abundance on detectability. Oikos 0: 1-10.

McGeoch, M.A., Butchart, S.H.M., Spear, D., Marais, E., Kleynhans, E. J., Symes, A., Chanson, J., Hoffmann, M. 2010. Global indicators of biological invasion: species numbers, biodiversity impact and policy responses. Diversity and Distributions 16: 95-108

Meek, P. D. 1999. The movement, roaming behaviour and home range of free-roaming domestic dogs, Canis lupus familiaris, in coastal New South Wales. Wildlife Research 26: 847-855.

Michalski F., Peres C.A. 2007. Disturbance-mediated mammal persistence and abundance-area relationships in Amazonian forest fragments. Conservation Biology 21: 1626-1640.

Miklósi, Á. 2007. Dog behaviour, evolution, and cognition. Oxford University Press, Oxford. 289p.

Mooney, H. A., Hobbs, R.J. 2000. Invasive species in a changing world. Island Press, Washington, DC.

Morey, D.F. 2010. Dogs: Domestication and the Development of a Social Bond. Cambridge University Press, Cambridge.

Murcia, C. 1995. Edge effectis in fragmented forests - Implications for conservation. . Trends in Ecology \& Evolution 10: 58-62.

Newsome, A. E., Noble, I. R. 1986. Ecological and physiological characters of invading species. In: Groves, R.H., Burdon, J.J. (Eds). Ecology of Biological Invasions. Cambridge University Press, Cambridge, England. p 1-20.

Noss, A.J., Cuellar, R.L.. 2001. Community attitudes towards wildlife management in the Bolivian Chaco. Oryx 35: 292-300.

Odell, E. A., Knight, R. L. 2001. Songbird and medium-sized mammal communities associated with exurban development in Pitkin country, Colorado. Conservation Biology 15: 1143-1150. 
Oldroyd, B.P. 1999. Coevolution while you wait: Varroa jacobsoni, a new parasite of western honeybees. Trends in Ecology and Evolution 14: 312-315.

Oliveira-Filho, A.T., Fontes, M.A. 2000. Patterns of Floristic differentiation among Atlantic Forests in southeastern Brazil and the influence of climate. Biotropica 32 (4b): 793-810.

Oliveira, G. 2011. Distribuição de mamíferos de maior porte em uma paisagem rural do Planalto Atlântico de São Paulo: Importância relativa da estrutura da paisagem e das características da população humana. São Paulo. Tese de Mestrado. Universidade de São Paulo, Brasil.

Oliveira, T.G., Cavalcanti, S.M.C. 2002. Identificação de Predadores de Animais Domésticos. In: Pitman, M.R.P.L., Oliveira, T.G.R., Paula, C., Indrusiak, C. (Eds.). Manual de identificação, prevenção e controle de predação por carnívoros. IBAMA, Brasília. p 31-50.

Ortega-Pacheco, A., Rodriguez-Buenfil, J.C., Bolio-Gonzales, M.E., Sauri-Arcco, C.H., Jiménez-Coelho, M., Forsberg, C.L. 2007. A survey of dog populations in urban and rural areas of Yucatan, Mexico. Anthrozoos 20 (3): 261-274.

Pardini, R., Bueno, A. de A., Gardner, T. A., Prado, P.I., Metzger, J. P.. 2010. Beyonde the Fragmentation Threshold Hypothesis: regime shifts in biodiversity across fragmented landscapes. PLOS ONE. 5(10): e13666.

Paschoal, A. M. O. 2008. Predadores em fragmentos de Mata Atlântica: estudo de caso na RPPN Feliciano Miguel Abdala, Caratinga, MG. Tese de Mestrado. Pontifícia Universidade Católica de Minas Gerais, Belo Horizonte, Brasil.

Paschoal, A. M. O., Massara, R. L., Santos, J. L.,Chiarello, A. G. 2012. Is the domestic dog becoming an abundant species in the Atlantic forest? A study case in southeastern Brazil. Mammalia 76: 67-76.

Pimentel, D., Lach, L., Zuniga, R., Morrison, D. 2000. Costs of nonindigenous species in the United States. BioScience 50: 53-65.

Prugh, L.R., Stoner, C.J., Epps, C.W., Bean, W.T., Ripple, W.J., Laliberte, A.S., Brashares, J.S. 2009. The rise of the mesopredator. BioScience 59: 779-791.

Pyare, S., Berger, J. 2003. Beyond demography and delisting: ecological recovery for Yellowstone's grizzly bears and wolves. Biological Conservation 113: 63-73.

R.2.11.0, The R Foundation for Statistical Computing. 2008, Viena, Austria. 
Raizada, P., Raghubanshi, A.S., Singh, J.S. 2008. Impact of invasive alien plant species on soil processes: a review. Proceedings of the National Academy of Sciences India, Section B, Biological Sciences 78: 288-298.

Randall, D.A., Marino, J., Haydon, D.T., Sillero-Zubiri, C., Knobel, D.L., Tallents, L.A., Macdonald, D.W., Laurenson, M.K. 2006. An integrated disease management strategy for the control of rabies in Ethiopian wolves. Biological Conservation 131: $151-162$.

Revilla, E., Palomero, F., Delibes, M. 2001. Edge-core effects and the effectiveness of traditional reserve conservation: Eurasian badgers in Donaña National Park. Conservation Biology 15: 148-158.

Ribeiro, M. C., Metzger, J. P., Maetensen, A.C., Ponzoni,F. J., Hirota, M.M. 2009. Brazilian Atlantic Forest: how much is left and how the remaining Forest is distributed? Implications for conservation. Biol. Conserv. 142: 1141-1153.

Robley, A., Gormley, A., Forsyth, D.M., Wilton, A.N., Stephens, D. 2010. Movements and habitat selection by wild dogs in eastern Victoria. Australian Mammalogy 32: 23-32.

Royle, J.A., Nichols, J.D. 2003. Estimating abundance from repeated presence-absence data or point counts. Ecology 84:777-790.

Royle, J.A. 2004. N-mixture models for estimating population size from spatially replicated counts. Biometrics 60: 108-115.

Rubin, H. D., Beck, A. M. 1982. Ecological behavior of free-ranging urban pet dogs. Applied Animal Ethology 8: 161-168.

Savolainen, P., Zhang, Y., Luo, J., Lundeberg, J., Leitner, T. 2002. Genetic evidence for an east Asian origin of domestic dogs. Science 298: 1610-1613.

Serpell, J. 2008. The domestic dog. Its evolution, behaviour, and interactions with people. Cambridge University Press, Cambridge. 268p.

Sher, A.A., Hyatt, L.A. 1999. The disturbed resource-flux invasion matrix: a new framework for patterns of plant invasion. Biological Invasions 1: 107-114.

Silva-Rodriguez, E.A., Sieving, K.E. 2011. Influence of care of domestic carnivores on their predation on vertebrates Conservation Biology 25: 808-815.

Smallwood, K.S. 1994. Site invasibility by exotic birds and mammals. Biological Conservation 69: 251-259. 
Srbek-Araujo A. C., Chiarello A. G. 2008. Domestic dogs in Atlantic forest preserves of south-eastern Brazil: a camera-trapping study on patterns of entrance and site occupancy rates. Brazilian Journal of Biology 68 (4): 771-779.

Stone, A.I., Lima, E.M., Aguiar, G.F.S., Camargo, C.C., Flores, T.A., Kelt, D.A., Marques-Aguiar, S.A., Queiroz, J.A.L., Ramos, R.M., Silva Jr, J.S. 2009. Nonvolant mammalian diversity in fragments in extreme eastern Amazonia. Biodiversity Conservation 18: 1685-1694.

Thorne, C. 2008. Feeding behaviour of domestic dogs and the role of experience. In: Serpell, J. (Ed.). The domestic dog: Its evolution, behaviour, and interactions with people. Cambridge University Press, Cambridge. p 103-115.

Torres, P.C. 2008. Ocorrência de cães domésticos (Canis familiaris) em fragmentos de Mata Atlântica em zona rural e urbana e sua relação com a ocupação humana no entorno. Tese de Mestrado. Universidade Estadual de Campinas, Campinas, Brasil.

Torres, P. T., Prado, P. I. 2010. Domestic Dogs in a Fragmented Landscape in the Brazilian Atlantic Forest: Abundance, Habitat use and Caring by Owners. Brazilian Journal of Biology.

Van de Bildt, M.W.G., Kuiken, T., Visee, A.M., Lema, S., Fitzjohn, T.R., Osterhaus, A.D.M.E. 2002. Distemper outbreak and its effect on African wild dog conservation. Emerging Infectious Diseases 8 (2): 211-213.

Van't Woudt, B.D. 1990. Roaming, stray, and feral domestic cats and dogs as wildlife problems. In: Davis, L.R., Marsh, R.E. (Eds.) Proceedings of the Fourteenth Vertebrate Pest Conference, University of Nebraska, Lincoln. p 291-295.

Vanak, A. T., Gompper, M. E. 2009a. Dogs Canis familiaris as carnivores: their role and function in intraguild competition. Mammal Rev. 39(4): 265-283.

Vanak, A.T., Gompper, M.E. 2009b. Dietary niche separation between sympatric freeranging domestic dogs and Indian foxes in central India. Journal of Mammalogy, 90 (5): 1058-1065.

Vanak, A. T., Gompper, M. E. 2010. Interference competition at the landscape level: the effect of free-ranging dogs on a native mesocarnivore. Journal of Applied Ecology, 47: $1225-1232$.

Vitousek, P.M., D’Antonio, C.M., Loope, L.L., Rejmánek, M., Westbrooks, R. 1997. Introduced species: a significant component of human-caused global change. New Zealand Journal of Ecology 21: 1-16. 
Wandeler, A.I., Matter, H.C., Kappeler, A., Budde, A. 1993. The ecology of canine rabies: a selective review. Rev. Sci. Tech. Off Int. Epiz. 12: 51-71.

Wattaola, G., Allan, J.R., Feare, C.J. 1996. Problems and management of naturalised introduced Canada geese Branta canadensis in Britain. In: Holmes, J.S., Simons, J.R. (Eds) The Introduction and Naturalisation of Birds, HMSO, London, UK. p. 71 78.

Whiteman, C., Matushima, E., Cavalcanti Confalonieri, U., Palha, M., da Silva, A., Monteiro, V. 2007. Human and domestic animal populations as a potential threat to wild carnivore conservation in a fragmented landscape from the Eastern Brazilian Amazon. Biological Conservation 138: 290-296.

Wilkie, D. 1983. Rayleigh Test for randomness of circular data. Journal of the Royal Statistical Society 32: 311-312.

Young, J. K., Olson, K. A., Reading, R. P., Amgalanbaatar, S., Berger, J. 2011. Is wildlife going to the dogs? Impacts of feral and free-roaming dogs on wildlife populations. BioScience 61: 125-132. 

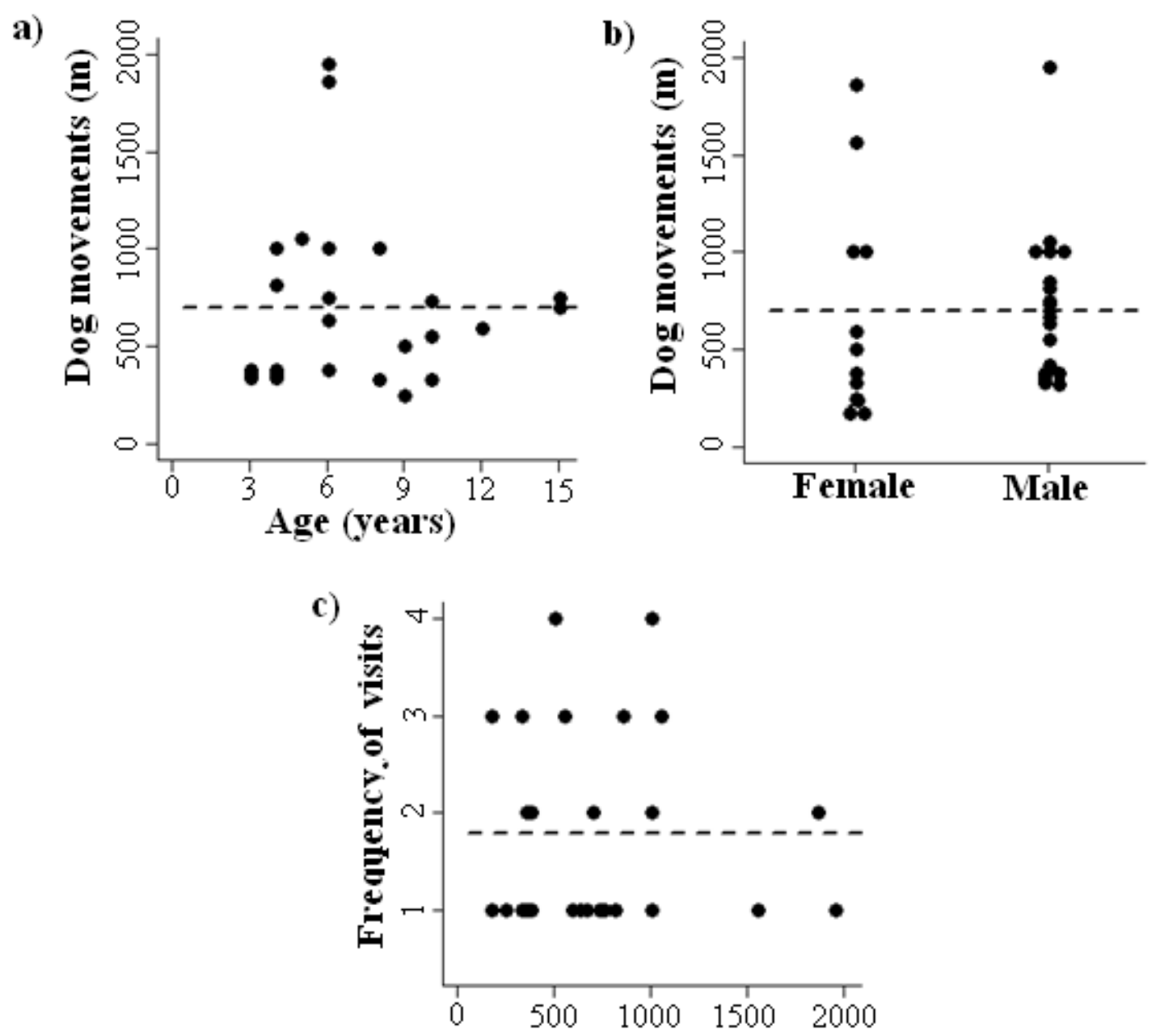

\section{Distance between household and visited fragment}

Figure 1: Dog movements, estimated through the linear distance from where they are raised to the fragments where they were recorded, as a function of the age (a) and sex (b) of individuals. (c) Frequency of visits of individual dogs as a function of the distance between the household where they were raised and the fragments where they were recorded. The dashed lines represent values estimated by the selected, constant model. 


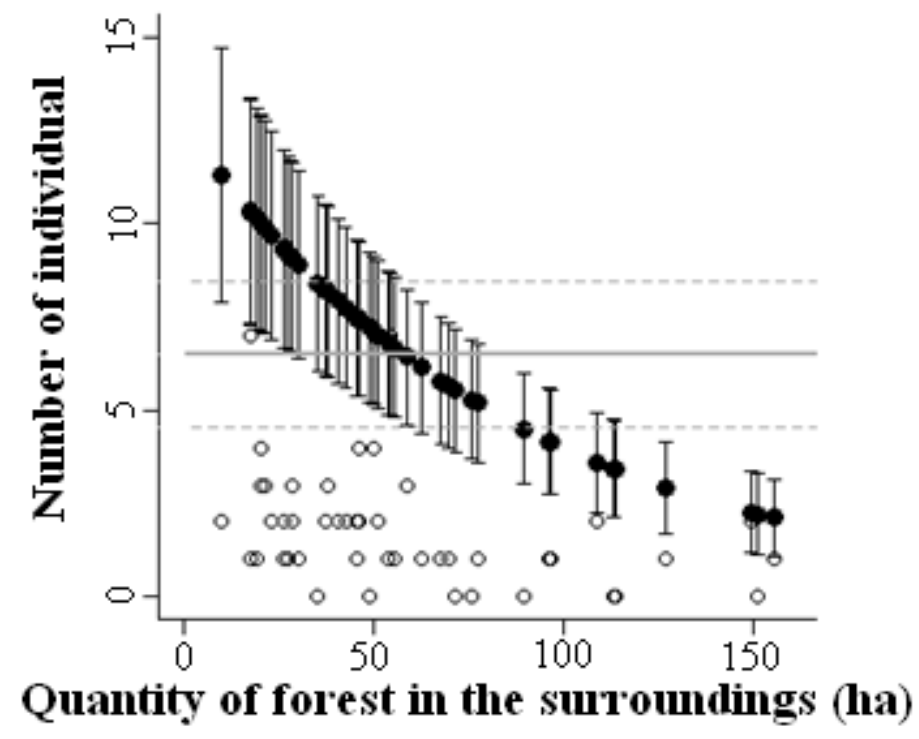

Figure 2: Number of individuals of domestic dogs that visit each of the 48 forest fragments as a function of the quantity of forests in surroundings. Filled dots: values estimated by the best abundance model; bars: standard deviations of these estimates; empty dots: observed values; solid grey line: values estimated by the constant model (without co-variables); grey dashed lines: standard deviation of these estimates. 


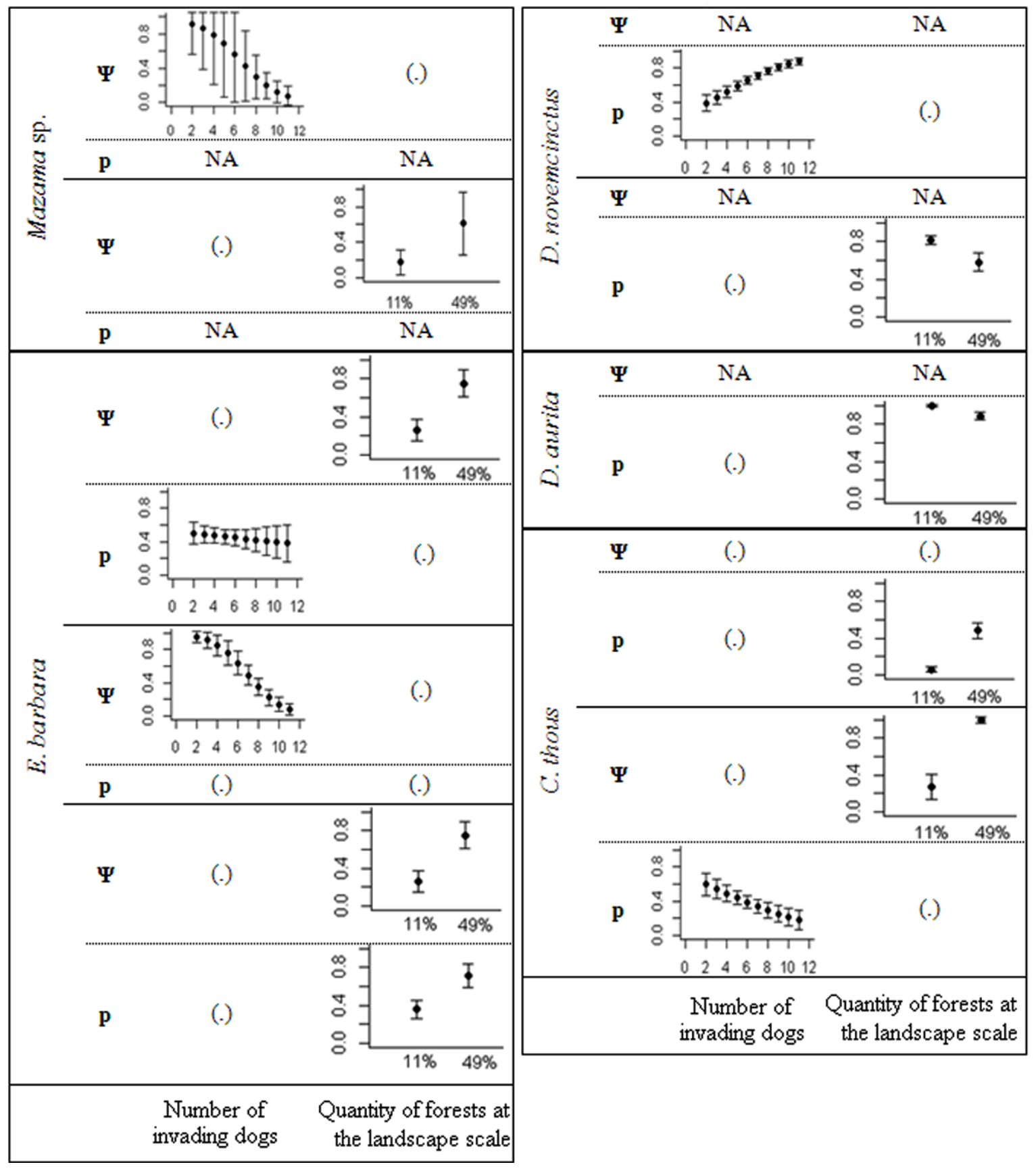

Figure 3: Probability of occupancy $(\Psi)$ and detectability (p) of native mammals in 48 forest fragments as a function of the estimated number of invading dogs and the quantity of forests at the landscape scale. The graphs of all simple, selected models for each species are presented. The bars in the charts represent standard errors. Dotted lines divide the graphs for the two parameters of the same selected model. (.) indicates that the selected model does not include co-variables for that parameter. NA indicates that the parameter was not modeled as a function of none of the co-variables for that species. 


\section{Supplementary Material}

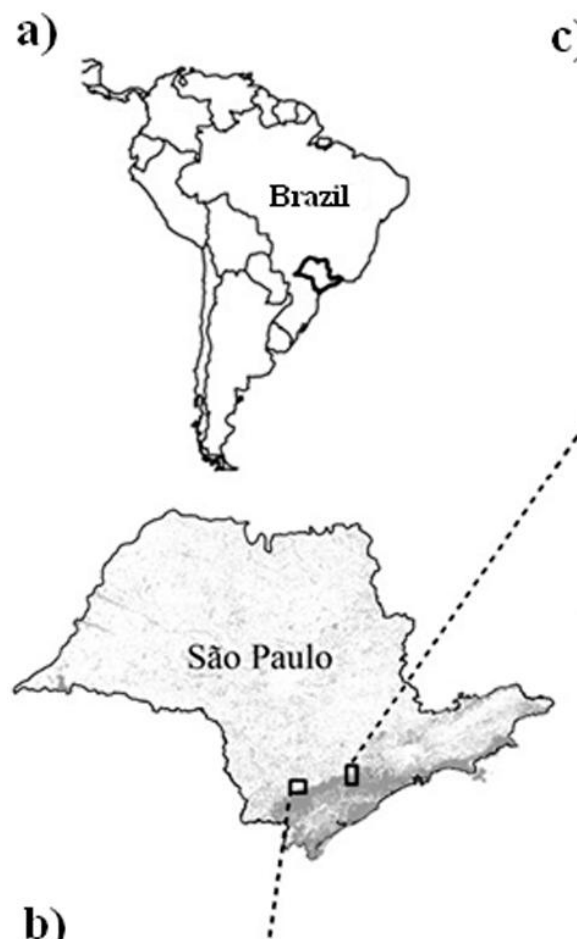

b)

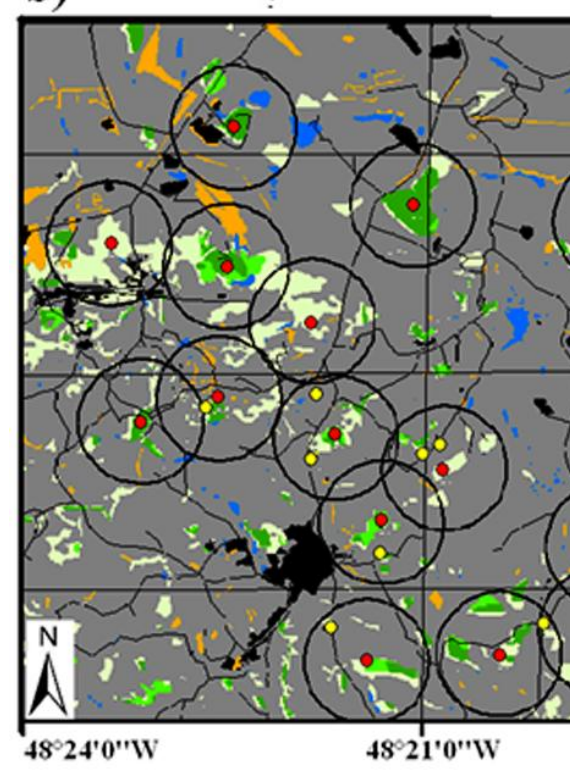

c)

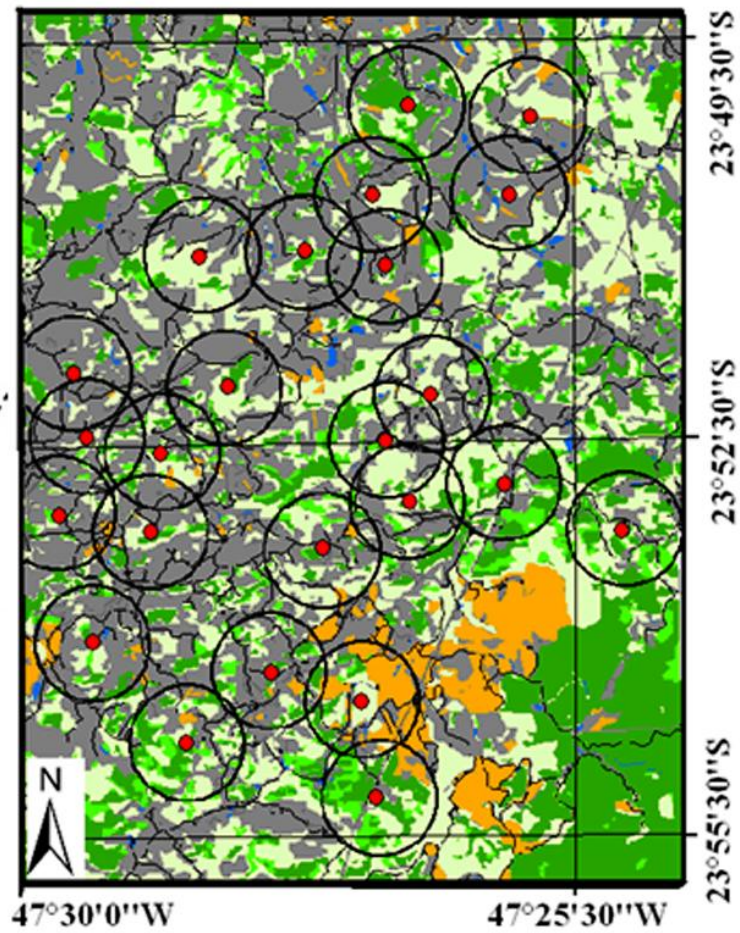

Figure S1: (a) Map of South America highlighting the State of São Paulo, Brazil, and map of this State showing forest remnants (in grey) and the location of the two study landscapes (black squares). (b) Land use map of the landscape in Ribeirão Grande and Capão Bonito, with $11 \%$ of remaining forest. (c) Land use map of the landscape in Tapiraí and Piedade, with $49 \%$ of remaining forest. 


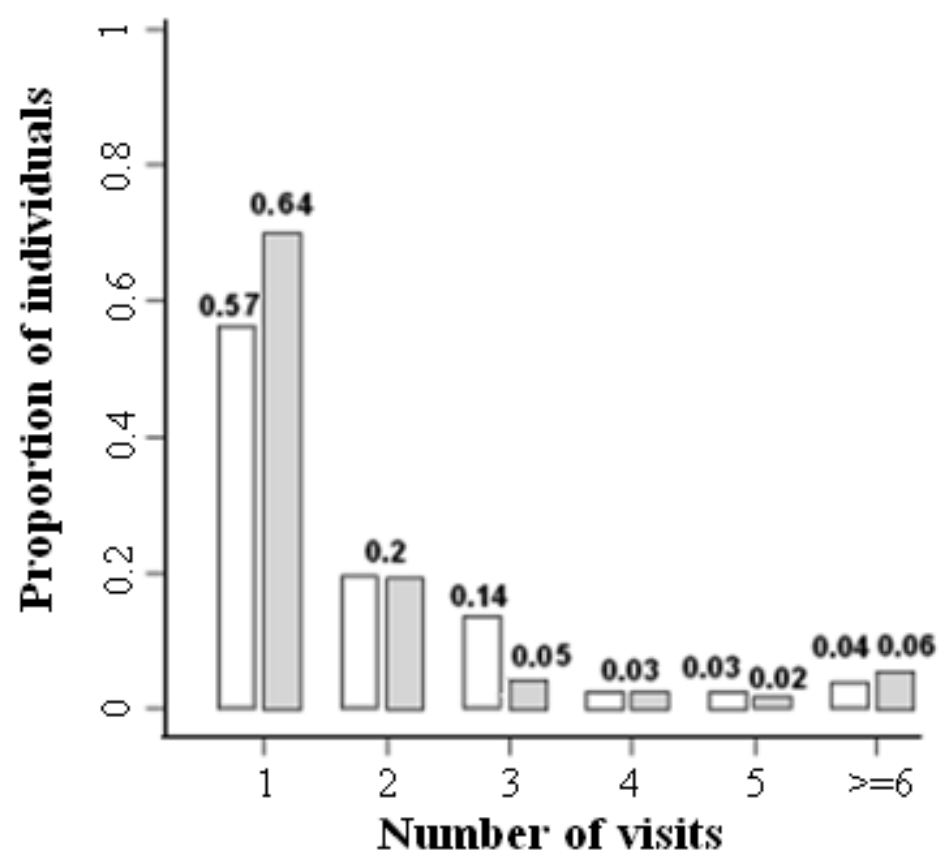

Figure S2: Proportion of individuals of dogs per number of visits (number of records excluding sequential records) across 48 forest fragments. White: landscape with $11 \%$ remaining forest; Grey: landscape with $49 \%$ remaining forest. 


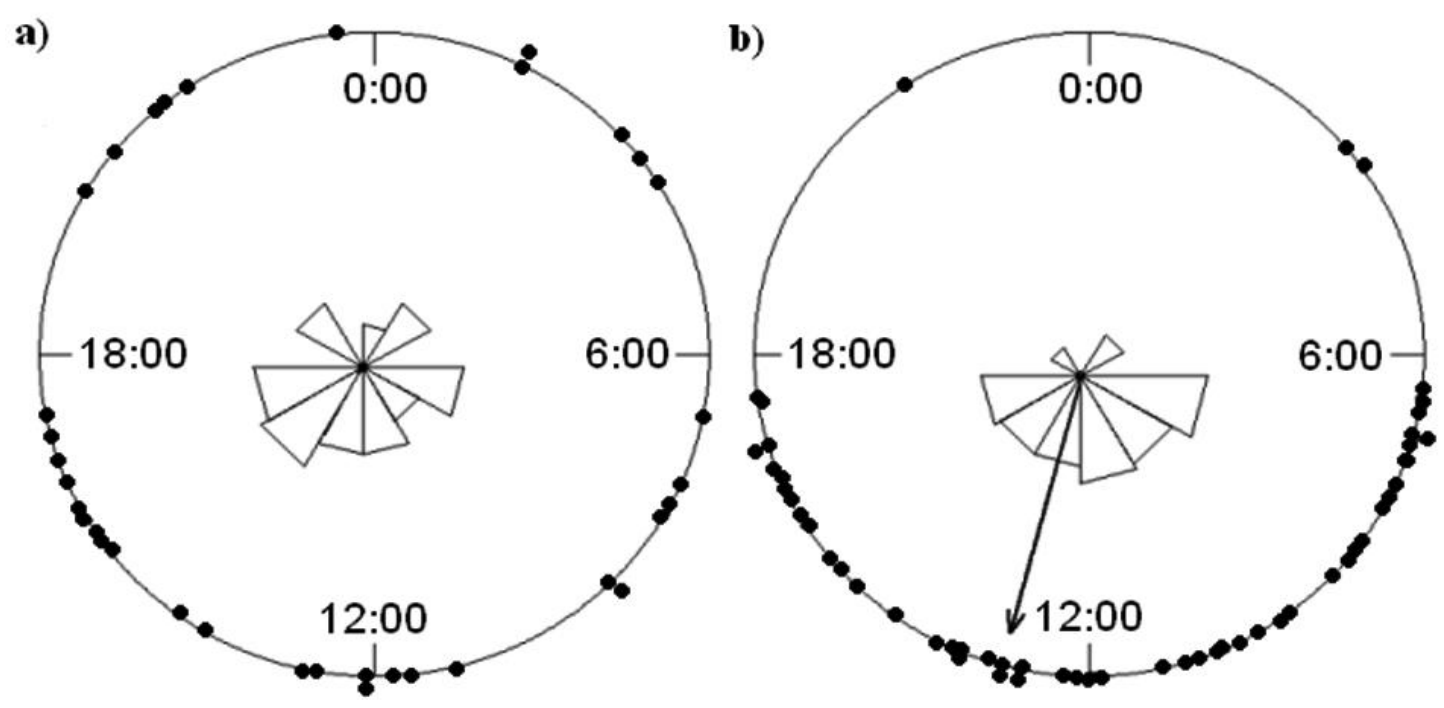

Figure S3: Time of the visit made by dogs to forest fragments: (a) landscape with $49 \%$ of remaining forest; (b) landscape with $11 \%$ of remaining forest. Arrow: time at which records concentrate; Triangles: quantity of records in 2-hour intervals. 
Table S1: Native mammals recorded across the 48 sampled fragments, showing the number of fragments, in total and per landscape, where each species was recorded, and the parameters modeled as a function of the estimated number of invading dogs and the quantity of forest at the landscape scale: $\Psi=$ Probability of occupancy and $\mathrm{p}=$ detectability.

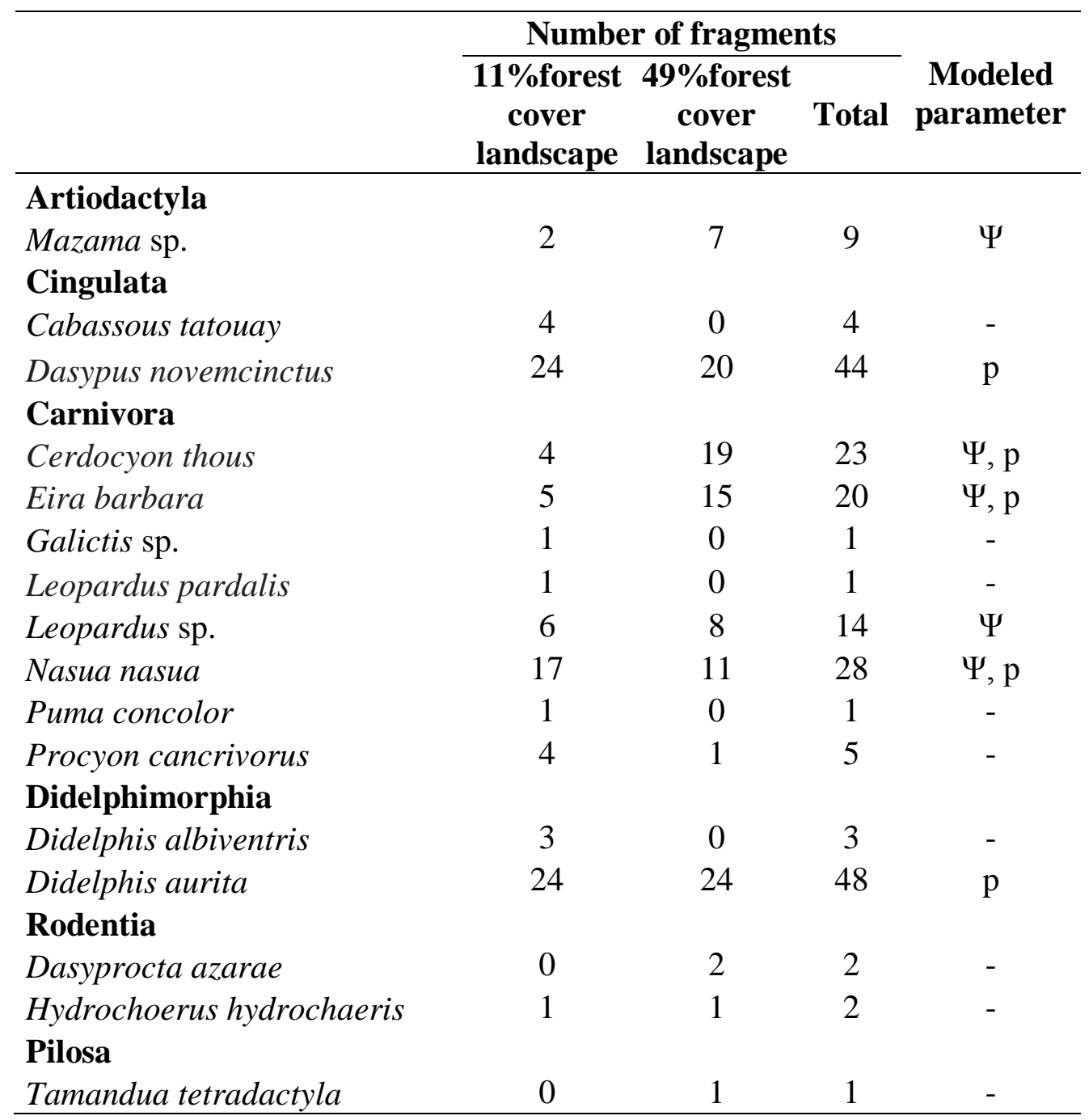


Table S2: Selection of models of dog movements (linear distance between where they were raised and visited fragment) as a function of age and sex. Models are ordered from the most plausible (from the lower to the higher AICc value) and the selected model is highlighted (light grey). For each model, information is provided about the modeled parameter, number of parameters (K), maximum likelihood (log-Lik), Akaike Information Criterion for small samples (AICc), difference between the AICc of the model and the best model ( $\triangle \mathrm{AICc})$, weight of evidence (Wi), and coefficients of covariables (+ positive; - negative).

\begin{tabular}{cccccccc}
\hline Models & $\begin{array}{c}\text { Modeled } \\
\text { parameter }\end{array}$ & K & log-Lik & AICc & $\Delta$ AICc & Wi & Coefficients \\
\hline Constant & - & 2 & -208.98 & 422.4 & 0 & 0.631 & \\
Sex & $\mu$ & 3 & -208.924 & 424.9 & 2.5 & 0.189 & + \\
Age & $\mu$ & 3 & -298.979 & 425 & 2.6 & 0.179 & - \\
\hline
\end{tabular}

Table S3: Selection of models of the number of visits of dogs to fragments as a function of the linear distance between the household they were raised and visited fragment. Models are ordered from the most plausible (from the lower to the higher AICc value) and the selected model is highlighted (light grey). For each model, information is provided about the modeled parameter, number of parameters $(\mathrm{K})$, maximum likelihood (log-Lik), Akaike Information Criterion for small samples (AICc), difference between the AICc of the model and the best model ( $\triangle \mathrm{AICc}$ ), weight of evidence (Wi), and coefficients of co-variables (+ positive; - negative).

\begin{tabular}{ccccccccc}
\hline Models & $\begin{array}{c}\text { Modeled } \\
\text { parameter }\end{array}$ & $\mathbf{K}$ & log-Lik & AICc & $\Delta$ AICc & Wi & Coefficients \\
\hline $\begin{array}{c}\text { Constant } \\
\text { Distance between } \\
\text { household and } \\
\text { visited fragment }\end{array}$ & $\lambda$ & 1 & -48.064 & 98.3 & 0 & 0.726 & \\
\hline
\end{tabular}


Table S4: Number and proportion of visits made by dogs, alone or in pairs, to forest fragments in landscapes with different proportions of remaining forests (11 and 49\%).

\begin{tabular}{cccccc}
\hline & & \multicolumn{2}{c}{ Alone } & \multicolumn{2}{c}{ In pairs } \\
\cline { 3 - 6 } & $\mathbf{N}$ & $\mathbf{n}$ & $\mathbf{( \% )}$ & $\mathbf{n}$ & $\mathbf{( \% )}$ \\
\hline $\mathbf{4 9 \%}$ of remaining forests & 36 & 28 & $(78)$ & 8 & $(22)$ \\
$\mathbf{1 1 \%}$ of remaining forests & 66 & 56 & $(85)$ & 10 & $(15)$ \\
Total & 102 & 84 & $(82)$ & 18 & $(18)$ \\
\hline
\end{tabular}

Table S5: Pearson correlation (r) and ANOVAs (F) among the independent variables used to model the number of invading dogs across 48 forest fragments. The values for which the tests were significant $(\mathrm{p} \leq 0.05)$ are highlighted with an *.

\begin{tabular}{cccc}
\hline & $\begin{array}{c}\text { Quantity of } \\
\text { forests in the } \\
\text { surroundings }\end{array}$ & $\begin{array}{c}\text { Quality of } \\
\text { forests in the } \\
\text { surroundings }\end{array}$ & $\begin{array}{c}\text { Quantity of forest } \\
\text { at the landscape } \\
\text { scale }\end{array}$ \\
\hline $\begin{array}{c}\text { Number of dogs } \\
\text { in the } \\
\text { surroundings }\end{array}$ & $\begin{array}{c}\mathrm{r}=-0.140 ; \\
\mathrm{p}=0.339\end{array}$ & $\begin{array}{c}\mathrm{r}=-0.263 ; \\
\mathrm{p}=0.070\end{array}$ & $\begin{array}{c}\mathrm{F}=1.611 \\
\mathrm{p}=0.211\end{array}$ \\
$\begin{array}{c}\text { Quantity of } \\
\text { forests in the } \\
\text { surroundings }\end{array}$ & $\mathrm{r}=-0.24$ & $\mathrm{~F}=32.92$ \\
$\begin{array}{c}\text { Quality of forests } \\
\text { in the }\end{array}$ & $\mathrm{p}=0.100$ & $\mathrm{p}=0.0007^{*}$ \\
surroundings & & \\
\hline
\end{tabular}


Table S6: Selection of abundance models for domestic dogs across 48 fragments in two landscapes with different proportions of remaining forest (11 and 49\%). Models are ordered from the most plausible (from the lower to the higher AICc value), the selected models are in dark grey and the models more plausible than the constant model in light grey. For each model, information is provided about the modeled parameter ( $\lambda=$ abundance; $r=$ probability of detection of the individual), number of parameters (K), maximum likelihood (log-Lik), Akaike Information Criterion for small samples (AICc), difference between the AICc of the model and the best model ( $\triangle \mathrm{AICc}$ ), weight of evidence (Wi), and coefficients of co-variables (+ positive; - negative). $\mathrm{D}=$ Number of dogs raised in the surroundings; $\mathrm{F}=\mathrm{Quantity}$ of forests in the surroundings; Q= Quality of forests in the surroundings; L= Quantity of forests at the landscape scale; E= Sampling effort; * = Interaction between two co-variables. $\lambda=$ abundance; $r=$ detectability; $()=$. constant parameter, not modeled as a function of co-variables.

\begin{tabular}{|c|c|c|c|c|c|c|c|c|c|c|c|c|}
\hline \multirow{2}{*}{ Models } & \multirow{2}{*}{$\begin{array}{c}\text { Modeled } \\
\text { parameter }\end{array}$} & \multirow{2}{*}{$\mathbf{K}$} & \multirow{2}{*}{ log-Lik } & \multirow{2}{*}{ AICc } & \multirow{2}{*}{$\triangle \mathrm{AICc}$} & \multirow{2}{*}{ Wi } & \multicolumn{6}{|c|}{ Coefficients } \\
\hline & & & & & & & D & $\mathbf{F}$ & $\mathbf{Q}$ & L $: \mathbf{D} * \mathbf{L}$ & $\mathbf{F} * \mathbf{L}$ & $\mathbf{Q}^{*} \mathbf{L}: \mathbf{E}$ \\
\hline $\mathrm{F}$ & $\lambda$ & 4 & -166.484 & 341.89 & 0 & 0.334 & & - & & 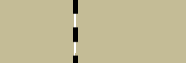 & & 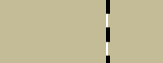 \\
\hline $\mathrm{F}+\mathrm{Q}+\mathrm{L}+\mathrm{Q}^{*} \mathrm{~L}$ & $\lambda$ & 7 & -163.250 & 343.31 & 1.41 & 0.134 & & - & - & - & & $-:$ \\
\hline$F+Q$ & $\lambda$ & 5 & -166.352 & 344.13 & 2.23 & 0.092 & & - & - & 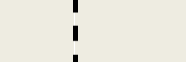 & & 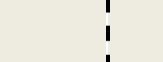 \\
\hline $\mathrm{D}+\mathrm{F}$ & $\lambda$ & 5 & -166.457 & 344.34 & 2.44 & 0.083 & + & - & & i & & ! \\
\hline $\mathrm{F}+\mathrm{L}$ & $\lambda$ & 5 & -166.467 & 344.36 & 2.46 & 0.082 & & - & & $+i$ & & ! \\
\hline $\mathrm{D}+\mathrm{F}+\mathrm{Q}+\mathrm{L}+\mathrm{Q}^{*} \mathrm{~L}$ & $\lambda$ & 8 & -162.961 & 345.61 & 3.71 & 0.044 & + & - & - & $-i$ & & $-i$ \\
\hline $\mathrm{F}+\mathrm{Q}+\mathrm{L}+\mathrm{F}^{*} \mathrm{~L}+\mathrm{Q}^{*} \mathrm{~L}$ & $\lambda$ & 8 & -162.976 & 345.64 & 3.74 & 0.043 & & - & - & -1 & + & -1 \\
\hline$F+Q+L$ & $\lambda$ & 6 & -166.349 & 346.74 & 4.84 & 0.025 & & - & - & $+i$ & & i \\
\hline $\mathrm{D}+\mathrm{F}+\mathrm{Q}$ & $\lambda$ & 6 & -166.357 & 346.76 & 4.86 & 0.024 & + & - & - & i & & i \\
\hline$F+L+F^{*} L$ & $\lambda$ & 6 & -166.443 & 346.93 & 5.03 & 0.022 & & - & & -1 & + & i \\
\hline $\mathrm{D}+\mathrm{F}+\mathrm{L}$ & $\lambda$ & 6 & -166.447 & 346.94 & 5.04 & 0.022 & + & - & & $+i$ & & i \\
\hline $\mathrm{D}+\mathrm{F}+\mathrm{Q}+\mathrm{L}+\mathrm{D} * \mathrm{~L}+\mathrm{Q} * \mathrm{~L}$ & $\lambda$ & 9 & -162.840 & 348.41 & 6.51 & 0.010 & + & - & - & $-1+$ & & $-\quad i$ \\
\hline $\mathrm{D}+\mathrm{F}+\mathrm{Q}+\mathrm{L}+\mathrm{F}^{*} \mathrm{~L}+\mathrm{Q}^{*} \mathrm{~L}$ & $\lambda$ & 9 & -162.919 & 348.57 & 6.67 & 0.010 & + & - & - & -1 & + & $\begin{array}{l}- \\
-\end{array}$ \\
\hline $\mathrm{L}$ & $\lambda$ & 4 & -169.893 & 348.71 & 6.81 & 0.009 & & & & $-i$ & & i \\
\hline $\mathrm{F}+\mathrm{Q}+\mathrm{L}+\mathrm{F}^{*} \mathrm{~L}$ & $\lambda$ & 7 & -166.348 & 349.49 & 7.59 & 0.006 & & - & - & $-i$ & + & ' \\
\hline
\end{tabular}




\begin{tabular}{|c|c|c|c|c|c|c|c|c|c|c|c|c|c|}
\hline $\mathrm{D}+\mathrm{F}+\mathrm{Q}+\mathrm{L}$ & $\lambda$ & 7 & -166.349 & 349.49 & 7.59 & 0.006 & - & - & - & $+i$ & & & \\
\hline $\mathrm{D}+\mathrm{F}+\mathrm{L}+\mathrm{D} * \mathrm{~L}$ & $\lambda$ & 7 & -166.407 & 349.61 & 7.71 & 0.005 & + & - & - & $-i$ & & & \\
\hline $\mathrm{D}+\mathrm{F}+\mathrm{L}+\mathrm{F}^{*} \mathrm{~L}$ & $\lambda$ & 7 & -166.442 & 349.68 & 7.78 & 0.005 & + & - & - & ! & & + & \\
\hline $\mathrm{Q}+\mathrm{L}+\mathrm{Q}^{*} \mathrm{~L}$ & $\lambda$ & 6 & -168.017 & 350.08 & 8.18 & 0.004 & & & - & $-i$ & & & - \\
\hline Constant & - & 3 & -171.851 & 350.24 & 8.34 & 0.004 & & & & ! & & & \\
\hline $\mathrm{D}+\mathrm{L}$ & $\lambda$ & 5 & -169.552 & 350.53 & 8.63 & 0.003 & + & & & $-i$ & & & \\
\hline $\mathrm{Q}+\mathrm{L}$ & $\lambda$ & 5 & -169.866 & 351.16 & 9.26 & 0.002 & & & - & $-i$ & & & \\
\hline $\mathrm{D}+\mathrm{F}+\mathrm{Q}+\mathrm{L}+\mathrm{D}^{*} \mathrm{~L}+\mathrm{F}^{*} \mathrm{~L}+\mathrm{Q}^{*} \mathrm{~L}$ & $\lambda$ & 10 & -162.856 & 351.65 & 9.75 & 0.002 & - & - & - & $-\quad !$ & + & + & - \\
\hline $\mathrm{D}+\mathrm{Q}+\mathrm{L}+\mathrm{Q}^{*} \mathrm{~L}$ & $\lambda$ & 7 & -167.442 & 351.68 & 9.78 & 0.002 & + & & - & $-i$ & & & - \\
\hline $\mathrm{D}+\mathrm{F}+\mathrm{Q}+\mathrm{L}+\mathrm{D}^{*} \mathrm{~L}$ & $\lambda$ & 8 & -166.334 & 352.36 & 10.46 & 0.001 & + & - & - & $-\quad !$ & + & & \\
\hline $\mathrm{D}+\mathrm{F}+\mathrm{Q}+\mathrm{L}+\mathrm{F}^{*} \mathrm{~L}$ & $\lambda$ & 8 & -166.347 & 352.38 & 10.48 & 0.001 & + & - & - & $-\quad !$ & & + & \\
\hline Q & $\lambda$ & 4 & -171.768 & 352.46 & 10.56 & 0.001 & & & + & ; & & & \\
\hline $\mathrm{E}$ & $r$ & 4 & -171.779 & 352.48 & 10.59 & 0.001 & & & & i & & & \\
\hline $\mathrm{D}$ & $\lambda$ & 4 & -171.781 & 352.49 & 10.59 & 0.001 & + & & & i & & & \\
\hline $\mathrm{D}+\mathrm{F}+\mathrm{L}+\mathrm{D} * \mathrm{~L}+\mathrm{F}^{*} \mathrm{~L}$ & $\lambda$ & 8 & -166.404 & 352.50 & 10.6 & 0.001 & + & - & & $+i$ & - & + & \\
\hline $\mathrm{D}+\mathrm{L}+\mathrm{D} * \mathrm{~L}$ & $\lambda$ & 6 & -169.407 & 352.86 & 10.96 & 0.001 & - & & & $-i$ & + & & \\
\hline $\mathrm{D}+\mathrm{Q}+\mathrm{L}$ & $\lambda$ & 6 & -169.551 & 353.15 & 11.25 & 0.001 & + & & - & $-\vdots$ & & & \\
\hline $\mathrm{D}+\mathrm{Q}+\mathrm{L}+\mathrm{D}^{*} \mathrm{~L}+\mathrm{Q}^{*} \mathrm{~L}$ & $\lambda$ & 8 & -166.794 & 353.28 & 11.38 & 0.0009 & - & & - & $-\quad$ & + & & - \\
\hline $\mathrm{D}+\mathrm{Q}$ & $\lambda$ & 5 & -171.638 & 354.70 & 12.8 & 0.0004 & + & & + & i & & & \\
\hline $\mathrm{D}+\mathrm{F}+\mathrm{Q}+\mathrm{L}+\mathrm{D}^{*} \mathrm{~L}+\mathrm{F}^{*} \mathrm{~L}$ & $\lambda$ & 9 & -166.332 & 355.40 & 13.50 & 0.0003 & + & - & - & $-i$ & + & + & \\
\hline $\mathrm{D}+\mathrm{Q}+\mathrm{L}+\mathrm{D} * \mathrm{~L}$ & $\lambda$ & 7 & -169.384 & 355.56 & 13.66 & 0.0003 & + & & - & $-i$ & + & & \\
\hline
\end{tabular}


Table S7: Occupancy models selected $(\triangle \mathrm{AICc} \leq 2)$ to describe the variation in the use of 48 forest fragments by native mammals. For each model, information is provided about the number of parameters (K), maximum likelihood (log-Lik), Akaike Information Criterion for small samples (AICc), difference between the AICc of the model and the best model ( $\mathrm{AICc}$ ), weight of evidence (Wi), and coefficients of covariables (+ positive; - negative). $\mathrm{D}=$ Estimated number of invading dogs; L= Quantity of forest at the landscape scale; E= Sampling effort; $*=$ Interaction between two co-variables; $\Psi=$ probability of occupancy; $\mathrm{p}=$ detectability; $()=$. constant parameter, not modeled as a function of co-variables.

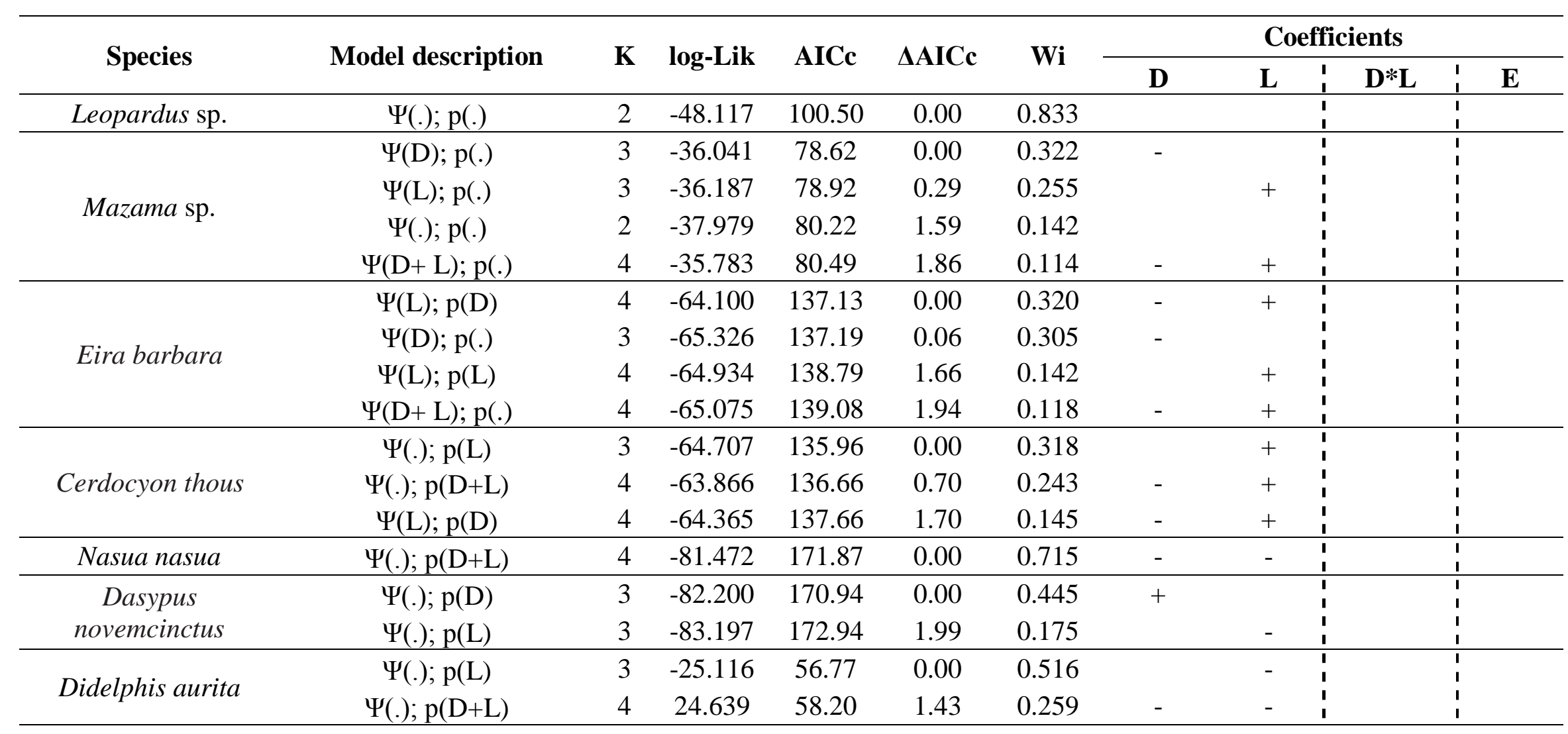


Appendix S1: Questionnaire used to interview the head of households within an area of 800 m radius around sampling sites in 24 fragments in the landscape with $11 \%$ of remaining forest.

\section{GENERAL INFORMATION ABOUT THE INTERVIEWEE}

- Date

- Name of the interviewee

- Household coordinates

\section{GENERAL INFORMATION ABOUT THE DOG RECORDED IN THE}

\section{FRAGMENT}

- Code of the fragment where the dog was recorded

- Code of the dog

- Dog age and sex

\section{QUESTIONS ABOUT THE WAY THE OWNER MANAGES THE DOG}

- Has your dog (NAME OF THE DOG) been vaccinated against rabies in the past year, that is, from day until today?

- Has your dog been vaccinated against Cynomosis and Parvovirosis in the past year, that is, from day until today?

- Do you leave your dog : 0) free during the day and all night, (1) tethered only at night, 2) tethered only at daytime, (3) tethered at daytime and night-time; (4) Other ways. Which?

- Why do you leave your dog tethered for at least one part of the day?

- How many times a day do you feed the dog

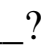

- $\quad$ Is your dog sterilized?

- How long have you had this dog?

\section{QUESTIONS ABOUT VISITS MADE BY DOGS TO FOREST FRAGMENTS}

- Does your dog (NAME OF THE DOG) go to the forest (EXPLAIN WHICH FOREST THE DOG WAS REGISTERED)?

- How often does your dog go to the forest ?

- When your dog goes to the forest, does it go: 0) alone; (1) in group; (2) I don't know.

- How many dogs go to the forest with your dog ? 


\section{QUESTIONS ABOUT THE ANIMALS HUNTED BY THE DOGS}

- Does your dog (NAME OF THE DOG) hunt other animals?

- Which animals has your dog already hunted? 


\section{Capítulo 2}

Do conversion of native forests into agroforests and agroforestry intensification favor the invasion of domestic dogs? 
Do conversion of native forests into agroforests and agroforestry intensification favor the invasion of domestic dogs?

Enrico Frigeri ${ }^{1}$, Camila R. Cassano ${ }^{2}$ and Renata Pardini ${ }^{3}$

${ }^{1}$ Departamento de Zoologia, Instituto de Biociências, Universidade de São Paulo, Rua do Matão, travessa 14, 101, CEP 05508-090, São Paulo, SP, Brazil

${ }^{2}$ Departamento de Ciências Biológicas, UESC, Campus Prof. Soane Nazaré de Andrade, Km 16, Rod. Ilhéus/Itabuna, Ilhéus, BA, Brazil

\begin{abstract}
Although the value of agroforests for biodiversity conservation has been highlighted in several studies, which showed that this production system can harbor several native species, little is known about their susceptibility to biological invasions. Drawing on a camera-trap dataset obtained across 30 agroforests and 9 forests in one of the main agroforestry region in Brazil, we investigated two hypotheses: (1) if the conversion of native forests into agroforests and agroforestry intensification favor the invasion by one of the most common exotic species in the world, the domestic dogs, and (2) if invasion by these animals is more associated with human presence in agroforests than in forests. While the observed and estimated number of invading dogs was higher in agroforests than in forests, the number of visits per individual did not vary between these two habitats. In contrast, agroforestry intensification was more associated with a higher number of visits than with a higher number of invading dogs. In both habitats, not only in agroforests, visits by domestic dogs were concentrated on times of the day and days of the week with greater human activity. Our work suggests that despite being permeable to native species agroforests may act as sink areas, given their susceptibility to invasion, limiting the value of this production system for biodiversity conservation. Similarly, agroforestry intensification, which has been occurring worldwide, may increase the risks of such invasions. Moreover, there seems to be a strong association between the invasion by domestic dogs and human activities which, however, do not depend on habitat type. Thus, the value of agroforestry mosaics for conservation depends on the management of invading species, and at least in the case of one of the most common and best distributed exotic species
\end{abstract}


worldwide, this management should focus on the habits and behavior of humans, both workers and residents in rural properties.

Key-words: cacao agroforest, alien species, Canis familiaris, Atlantic forest, invasive species, wildlife-friendly agriculture, land-sharing strategies.

\section{Resumo}

Apesar da importância de sistemas agroflorestais para a conservação da biodiversidade ter sido relatada em diversos estudos, que mostraram que esse sistema de produção pode abrigar várias espécies nativas, pouco se sabe sobre sua susceptibilidade às invasões biológicas. Baseando-se em um conjunto de dados obtidos com armadilhas fotográficas em 30 agroflorestas e 9 florestas em uma das principais regiões agroflorestais do Brasil, investigamos duas hipóteses: (1) se a conversão de florestas nativas em sistemas agroflorestais e a intensificação de sistemas agroflorestais favorecem a invasão por uma das espécies exóticas mais comum do mundo, os cães domésticos, e (2) se a invasão por esses animais está mais associada com a presença humana em sistemas agroflorestais do que em florestas. Apesar do número observado e estimado de cães invasores ter sido maior em agroflorestas do que em florestas, o número de visitas por indivíduo não variou entre esses habitats. Ao contrário, a intensificação das agroflorestas esteve mais relacionada com um maior número de visitas do que com um maior número de cães invasores. Em ambos os habitats, e não só nas agroflorestas, as visitas dos cães domésticos foram concentradas em períodos do dia e dias da semana com maior atividade humana. Nosso trabalho sugere que, apesar de serem permeáveis às espécies nativas, as agroflorestas podem agir como áreas dreno, dada a sua susceptibilidade à invasão, o que limita o valor deste sistema de produção para a conservação da biodiversidade. Da mesma forma, a intensificação de sistemas agroflorestais, processo que vem ocorrendo em todo o mundo, pode aumentar os riscos das invasões. Além disso, parece haver uma forte associação entre a invasão de cães domésticos e as atividades humanas, independente do habitat. Assim, o valor de mosaicos agroflorestais para a conservação depende do manejo das espécies invasoras, e pelo menos no caso de uma das espécies exóticas mais comuns e bem distribuídas do mundo, este manejo deve incidir sobre os hábitos e comportamento do ser humano, tanto dos trabalhadores quanto dos residentes nas propriedades rurais. 
Palavras-chave: agroflorestas de cacau, espécies invasoras, Canis familiaris, Mata Atlântica, espécies exóticas, agricultura "wildlife-friendly", estratégia "land-sharing".

\section{Introduction}

Reconciling biodiversity and ecosystem service conservation with farming production is presently one of the great challenges of mankind (Sala et al., 2000; Foley et al., 2005). This reconciliation has been discussed from two distinct perspectives (Phalan et al., 2011). The land-sparing approach is based on agriculture intensification, i.e. the increase in production per unit of area, so that larger areas of native vegetation can be preserved (Balmford et al., 2005; Green et al., 2005). In contrast, the land-sharing approach is based on extensive management practices (wildlife-friendly), which, despite occupying comparatively larger areas to obtain the same production, minimize the local damage to wildlife compared to more intensively-managed areas (Perfecto \& Vandermeer, 2008; Phalan et al., 2011).

One of the main production systems associated with the land-sharing approach is agroforestry, a system of extensive management where agricultural products are cultivated in association with native or exotic trees (Somarriba, 1992). Nowadays, extensive areas of native forests in the tropics have been converted into cacao (Theobroma cacao) and coffee (Coffea spp.) agroforests (Beer et al., 1998; Rice \& Greenberg, 2000; Bhagwat et al., 2008), creating agroforestry mosaics. Although, several studies have suggested that these mosaics may favor the reconciliation of agricultural production and conservation of biodiversity (Tylianakis et al., 2006; Schroth \& Harvey, 2007; Perfecto \& Vandermeer, 2008), the agroforests have been experiencing a marked process of intensification (Juhrbandt et al., 2010; Tscharntke et al., 2011). In order to increase short term income levels, shaded agroforests have been converted into monocultures with little or no shade (Perfecto et al., 2005; Franzen \& Borgerhoff-Mulder, 2007; Tscharntke et al., 2011), approaching this agroforests to the land-sparing approach.

Agroforests have been shown to harbor a significant component of native faunas (Schulze et al., 2004; Cassano et al., 2009, Cassano et al., 2012), especially in comparison to more intensively-managed areas. However, given that disturbance facilitates invasion (Newsome \& Noble, 1986; Smallwood, 1994), agroforests, especially those more intensively-managed, should be more susceptible to invasion 
than forest remnants. This greater susceptibility to invasion may limit the value of agroforests for biodiversity conservation.

Biological invasions have been growing worldwide (Hulme, 2009; McGeoch et al., 2010), and are today the second greatest threat to biodiversity (Vitousek et al., 1997, Baillie et al., 2004), affecting different levels of ecological organization, from individual behavior (Creel \& Christianson, 2008) to ecosystem processes (Raizada et al., 2008). It has already been shown that generalist and open area species tend to increase in agroforests in detriment of forest specialists (Pardini et al. 2009; Waltert et al. 2011). Although scarce, evidence in the literature mainly on plants and invertebrates (Richardson et al., 2004; Bos et al., 2008; but see Faria et al., 2006 and Weist et al., 2010) indeed indicates that these systems are more susceptible to invasions than native forests.

Among the potentially invasive species, one which is very common and widely distributed is the domestic dog, the most abundant carnivore in the world (Vanak \& Gompper, 2010), introduced wherever man has settled (Wandeler et al., 1993; Pimentel et al., 2000) for property protection, livestock management, company and hunting (Hart, 2008; Khan, 2009). In rural landscapes, dogs usually follow men in their work (Serpell, 2008), moving freely and possibly causing damage to wildlife (Randall et al., 2006; Vanak \& Gompper, 2009; Young et al., 2011; Hughes \& Macdonald, 2013). Thus, the presence of domestic dogs in agroforests should be facilitated by and associated with human activities in these plantations, which are more frequent in more intensively-managed agroforests.

Although the number of studies on the invasion by domestic dogs in tropical forest remnants has been increasing (e.g. Ssbek-Araujo \& Chiarello, 2008; Lacerda et al., 2009), little is known about the presence of dogs in agroforests. A previous study has shown that the number of records of domestic dogs is higher in agroforests than in forests (Cassano et al., 2012), and that this variable explains better the distribution of native mammals among agroforests than the quantity of forests in the surroundings or than the local vegetation simplification (Cassano et al., in press). Despite the existing evidence that dogs pose a threat to wildlife in agroforests, we do not know whether the high number of records of dogs in agroforests results from frequent visits of few individuals or from the presence of several individuals, whether the invasion is 
strongly associated with human activities and how management intensification in this type of system affects the intensity of invasion.

In this study we investigate three interrelated hypotheses: (1) the conversion of native forests into agroforests and (2) agroforestry intensification favor the invasion by domestic dogs, and (3) the invasion by these exotic animals is more associated with human activity in agroforests than in forests. Drawing on a dataset from a standardized sampling protocol with camera-traps across 30 cacao agroforests and 9 forests in an agroforestry mosaic of one of the most important agroforestry regions in Brazil, we verified if:

(1) the number of domestic dogs and the number of visits are higher in agroforests than in forests, and (2) among agroforests, in those more intensively-managed;

(3) days and times of visits by dogs are more concentrated in the periods of greater human activity in agroforests than in forests.

\section{Methods}

\section{Study area}

The study was carried out in a 64000 ha agroforestry mosaic situated in the Una and Arataca municipalities, in the cacao growing region of southern Bahia (SEI, 1999). The climate is Af, that is, hot and humid, with no well-defined dry season (Köppen, 1948), average annual precipitation varies between 1200 and $1800 \mathrm{~mm}$ and average annual temperature is $24.5^{\circ} \mathrm{C}$, maximum temperature $38^{\circ}$ and minimum $7^{\circ}$ (Mori, 1983). The region was originally covered by Atlantic Forest, classified as "Southern Bahian Moist Forest" (Thomas, 2003). Nowadays 50\% of the landscape is covered by native forests and $15 \%$ by cacao agroforests (Figure S1). The studied agroforests, locally known as cabrucas, are structurally simplified environments, where native trees from the original forest are left to shade the plantation, the understory is composed predominantly of cacao trees and the herbaceous vegetation is absent or periodically removed (Sambuichi, 2002).

The agroforestry mosaic harbors a simplified large mammal fauna, mainly dominated by opossums (Didelphis aurita), armadillos (Dasypus novemcinctus, and Euphractus sexcinctus), and other medium-sized species (Agouti paca, Eira barbara, Procyon cancrivorus, Nasua nasua, Cerdocyon thous, Leopardus spp.), but is an 
important area for species of conservation concern, especially primates (Leontopithecus chrysomelas and Callithrix kuhlii). Some species, like the lesser anteater (Tamandua tetradactyla), the agouti (Dasyprocta agouti) and the deer (Mazama spp.) are rare, and others were not recorded (Panthera onca, Puma concolor, Tapirus terrestris, Tayassu pecari and Pecari tajacu) (Cassano et al., 2012).

\section{Sampling design}

We sampled 39 sites across the agroforestry mosaic, 30 in cabrucas and 9 in forest remnants adjacent to 9 of these cabrucas. The minimum distance among the sampled cabruca sites was $1500 \mathrm{~m}$, and the distance between the sites of the 9 cabruca-forest pairs varied from 200 to $450 \mathrm{~m}$ (Figure S1). The 30 cabruca sites were selected to encompass ample variation in management intensification (but assuring in all cases that the plantations were to some degree shaded by native trees) and in the size of adjacent forest remnants (Cassano et al., in press).

\section{Data collection}

Recording domestic dogs

A camera-trap was installed in each of the 39 sampling sites, placed at $25 \mathrm{~cm}$ from the ground, baited with bananas and sardine. The traps in all sites were active over four sampling sessions of 30 days each, which occurred from July to October 2007 and 2008 and from January to April 2008 and 2009. Due to problems with trap malfunction, the sampling effort varied from 94 to 127 camera-days among the 9 forest remnants, and from 90 to 126 camera-days among the 30 cabrucas, totaling, respectively, 1021 and 3325 camera-days in each habitat and 4346 camera-days in the agroforestry mosaic.

Recorded dogs were identified from characteristics such as fur color, sex, size, breed, scars, and natural or artificial marks to obtain the number of individuals per sampling site, and the days and times of visits.

\section{Management intensification of the cabrucas}

In the same period as data were collected with camera-traps, in all 30 sampled cabrucas we (1) interviewed the workers to obtain the annual frequency of herbaceous vegetation clearance, and (2) quantified 13 variables associated with vegetation structure and management intensification in four plots of $10 \times 25 \mathrm{~m}$, every $20 \mathrm{~m}$, in an area of $25 \times 100 \mathrm{~m}$ (Table S1). In these plots, we computed banana stems, 
computed and measured the height and diameter of all shade trees in the plantation with at least $10 \mathrm{~cm}$ diameter at breast height $(\mathrm{DBH})$, classifying them as native or exotic trees, and estimated the proportion of canopy of each of them that was connected to the canopy of adjacent trees through an index that varied from 0 to 4 (corresponding to the number of tree crown quadrants connected to adjacent trees). In each half parcel $(5 \times 25 \mathrm{~m})$ we counted and measured the height and diameter of all cacao trees and we estimated the proportion of canopy that was connected to the adjacent cacao trees. Finally, in each parcel we measured the height of the herbaceous vegetation, through the height of the tallest herbaceous plant inside 12 sub-plots of $0.5 \times 0.5 \mathrm{~m}$, arranged at every $5 \mathrm{~m}$ along one of the sides and in the center of each 10 x $25 \mathrm{~m}$ plot. The shade trees and the cacao trees were quantified at the end of the second sampling sessions with camera-traps, and the herbaceous vegetation height, which varies temporally, was quantified three times, at the end of the second, third and fourth sampling session.

\section{Data analysis}

Number of individuals, number of visits per individual, times and days of visits in agroforests and adjacent forests

Considering the 9 cabruca-forest pairs, we used abundance models (Royle, 2004) modified from occupancy models (Mackenzie et al., 2002), to investigate the influence of the type of habitat (cabruca or forest remnant) on the number of invading dogs. These models contain two parameters: abundance $(\lambda)$ and probability of detection ( $r$, the probability that an individual of a species is detected), estimated from the capture history of individuals among sampling sessions (which in this case were four) (Royle, 2004). The set of candidate models included a constant model (both parameters $r$ and $\lambda$ constant), a model with detectability ( $r$ ) as a function of sampling effort ( $\lambda$ constant), a model with abundance $(\lambda)$ as a function of the type of habitat and detectability $(r)$ as a function of sampling effort, and a model with abundance $(\lambda)$ as a function of the nine cabruca-forest pairs and detectability $(r)$ as a function of sampling effort.

We compared the number of visits per individual between the two habitats with the Kolmogorov-Smirnov test, using the proportion of individuals in classes of number of visits, including all records excepting the sequential records (i.e. pictures taken from the same individual in the same camera within intervals shorter than 1 
hour which are likely to occur because dogs stay in front of the camera eating the bait).

To test if visits by dogs are more concentrated at times of greater human activity in cabrucas than in forests, we used the following tests: the Watson test of homogeneity between two circular samples (Jammalamadaka \& SenGupta, 2001) to test if the time of visits differs between the two habitats (cabrucas and forests); the Rayleigh test (Wilkie, 1983), to verify if visits in each habitat are uniformly distributed along the day and, if not, the Von Mises estimate (Jammalamadaka \& SenGupta, 2001) to estimate the time when visits are concentrated. Finally, to test if the days of visits by dogs are more associated with working days in cabrucas than in forests, we used Chi-square tests, considering two classes, working days (Monday to Saturday) and rest days (Sunday) and calculating the expected number from the proportion of days in each of these two classes. For these analyses on the time and days of visits, we excluded the sequential records of the same individual and used the median time or day of record for each individual.

Agroforestry intensification and the number of individuals and visits

We constructed a PCA to rank the 30 sampled cabrucas according to the 14 measured vegetation variables, and used the scores of the sites on the first two axes of this analysis as variables indicating management intensification (see Results).

To investigate the influence of management intensification on (1) the number of visits and on (2) the number of invading dogs, we used, respectively, generalized linear models (GLM) and abundance models modified from occupancy models (Royle, 2004). The number of visits was modeled as a Negative Binomial variable using $\log$ as the link function, and the set of candidate GLM models included a constant model with the parameters average $(\mu)$ and dispersion index $(\mathrm{k})$ constant, a simple model with $\mu$ as a function of sampling effort ( $\mathrm{k}$ constant), three additive models, two with $\mu$ as a function of sampling effort and the scores of each of the two axes of PCA separately ( $\mathrm{k}$ constant) and one with $\mu$ as a function of sampling effort and the scores of the two axes of PCA jointly (k constant). Again we considered all records excepting the sequential ones.

Similarly, for the number of invading dogs, the candidate set of abundance models included a constant model (with abundance $(\lambda)$ and detectability $(r)$ constant), a model with $r$ as a function of sampling effort ( $\lambda$ constant), two simple models with $r$ 
as a function of sampling effort and $\lambda$ as a function of the scores of each one of the two axes of PCA separately, and an additive model with $r$ as a function of sampling effort and $\lambda$ as a function of the scores of the two axes of PCA jointly.

In all abundance models, given the small size of sampling sites in relation to the home range of dogs, we interpreted the parameter abundance as the number of individuals that use the sampling sites (McCarthy et al., 2013). In all model selections, we compared models using the Akaike Information Criterion (AICc) corrected for small sample size (Burnham \& Anderson, 2002). Following these authors, models that present a difference in their AICc values relative to the firstranked model $(\triangle \mathrm{AICc})$ smaller or equal to 2 are considered equally plausible. All the analyses were performed in Program R, using the packages "bbmle","car", "CircStats", "chron", "MASS", and "Unmarked" (R.2.11.0, The R Foundation for Statistical Computing. 2008, Vienna, Austria).

\section{Results}

Number of individuals, number of visits per individuals, times and days of visits in agroforests and adjacent forests

In the nine cabruca-forest pairs, we identified $80 \mathrm{dogs}$ in total, with only three of them being recorded in both habitats. Of this total, 65 dogs were recorded in agroforests, with all nine sites having dog records, and each of them being visited on average by 5.2 individuals ( $\mathrm{SD}=2.7)$. In adjacent forests, 18 dogs were recorded in six out of nine sites, with an average of 2 individuals $(\mathrm{SD}=2.2)$ per forest site.

Indeed, only the model with abundance as a function of habitat type and detectability as a function of sampling effort was selected (Table S2), indicating that the number of invading dogs is higher in agroforests than in forest remnants (Figure 1, Table S2). The estimated average number of invading dogs per site was 11 in agroforests and seven in forests, with detectability of 0.18 . The estimated total number of dogs was 99 in the set of nine agroforests, and 63 in the set of nine forests. However, the proportion of individuals in classes of numbers of visits did not differ significantly between the habitats $(D=0.57 ; p=0.24)$; in both of them most dogs made only one visit (Figure 2).

In both habitats visits by dogs were not homogeneously distributed during the day (Rayleigh test: for forests $\mathrm{p}<0.01$; for cabrucas $\mathrm{p}<0.01$ ), concentrating at 13:14 h 
in forests and 12:43 in cabrucas (Figure 3), and the time of visits did not differ between the two habitats (Watson homogeneity test: $\mathrm{p}=0.15$ ). Similarly, in both habitats (and not only in the cabrucas, as expected) visits by dogs tend to be concentrated on working days (marginally significant result of Chi-square tests in both cases; forests $\chi^{2}=0.70 ; \mathrm{p}=0.08$; cabrucas $\chi^{2}=0.67 ; \mathrm{p}=0.08$ ) (Table S3).

Agroforestry intensification and number of individuals and visits

The first axis of the PCA analysis explained $27.3 \%$ of the variation in vegetation structure among the 30 cabrucas. This axis represents a gradient of management intensification, higher values representing cabrucas with more cacao shrubs and banana stems, higher connectivity of cacao shrubs and higher annual frequency of herbaceous vegetation clearance, and lower height and connectivity of shade trees (Figure S2). Thus, this axis represents the decrease in shading and the increase in the control of the herbaceous vegetation and in the density of cacao shrubs and banana stems. The second axis of the PCA explained $20.9 \%$ of the variation in vegetation structure and seems less directly related to agroforestry intensification, and more associated with the age of agroforests. Higher values of this axis represent mainly cabrucas with smaller native trees, but with larger cacao shrubs (Figure S2).

Two models were selected as plausible to describe the number of visits by dogs across agroforests (Table S4). Both contain sampling effort as an independent variable and indicate, as expected, that the higher the sampling effort, the higher the number of visits. The first-ranked model contains also management intensification (PCA1) as an independent variable, indicating that the number of visits by dogs is higher in more intensively-managed cabrucas.

Instead, for the number of invading dogs, only the model with sampling effort as a co-variable of the detectability parameter $(r)$ was selected, indicating that the higher the sampling effort, the higher the detectability (Table S5). The estimated average number of dogs that use each agroforest was 12 individuals, with 360 dogs using the set of all 30 agroforests, with detectability varying from 0.06 to 0.27 ( $\mathrm{X}=$ 0.12 and $\mathrm{SD}=0.03$ ). It is noteworthy, however, that, although not among the selected models, the model with management intensification (PCA1) as co-variable of the parameter abundance is ranked second, indicating that management intensification influences positively the number of invading dogs, but this influence is weaker than that observed on the number of visits (Figure $4 \mathrm{~b}$ and Table S5). 


\section{Discussion}

The observed and estimated number of domestic dogs suggests that the intensity of invasion by this exotic species in agroforestry mosaics is high, what may pose a threat to the fauna of these landscapes. More importantly, our results corroborate the hypothesis that the conversion of native forests into agroforests, as wells as management intensification across agroforests, favor the invasion by domestic dogs. On the other hand, despite having found evidence that visits by dogs are associated with times and days with higher human activity, this association seems to occur independently of the type of habitat and is not stronger in agroforests than in forests.

As expected, the number of invading dogs was higher in agroforests than in forests. On the other hand, the number of visits per individual did not vary between the two habitat types. As in other studies (Paschoal, 2008; Srbeck-Araujo \& Chiarello, 2008), most individuals were recorded only once both in forests and in agroforests. Thus, the higher number of records of dogs in agroforests than in forests in the study region (Cassano et al., 2012) results mainly from the entrance of a large number of dogs, rather than from frequent visits of the same individuals, which certainly increases the probability of disease transmission to wild animals. It is important to note, however, that although not significant the number of visits was higher in agroforests, indicating that, besides a consistently higher number of individuals, at least part of them enters this habitat more frequently than forests.

If contrasted to native forests, agroforests present a simplified vegetation structure, which may facilitate the access and displacement of dogs, leading to a higher number of dogs, since these animals move preferably through open environments (May \& Norton, 1996; Manor \& Saltz, 2004). Also, man alters native fauna, either directly by hunting, or indirectly by thinning the vegetation and changing plant species, with several native species becoming less frequent in agroforests than in forests (Faria et al., 2006; Weist et al., 2010; Cassano et al., 2012). Therefore, the simplification of the native fauna may also be responsible for the higher number of dogs in agroforests than in forests (Cox, 1999; Sher \& Hyatt, 1999; Mooney \& Hobbs, 2000; Conover, 2002; D'Antonio \& Meyerson, 2002). Nevertheless, the number of people entering managed systems such as agroforests should be much higher, and the higher number of dogs in this agricultural system may 
be simply linked to the behavior of dogs to follow their owners at work (Serpell, 2008).

On the contrary, across agroforests the positive effect of management intensification was stronger on the number of visits than on the number of invading dogs. More intensively-managed plantations, associated, among other things, with a higher frequency of herbaceous vegetation clearance and a higher number of cacao shrubs, require a higher frequency or longer periods of stay of workers, and result in more open vegetation close to the ground. Both characteristics may lead to the increase in the number of visits by dogs in more intensified agroforests, either because they follow their owners who enters more frequently or stay longer in these plantations, or because their displacement is facilitated in more open environments (May \& Norton, 1996; Manor \& Saltz, 2004; Serpell, 2008). However, these characteristics do not necessarily affect the number of dogs that visit agroforests, which should depend also on other factors such as the quantity of dogs raised in the surroundings (i.e. propagule pressure; Lockwood et al., 2005; Gurevitch et al., 2011) or on the number of workers, probably more associated with plantation size and other socioeconomic factors than with management intensification.

It is possible that the higher number of invading dogs in agroforests compared to forests is associated with the larger number of people who enter and stay in these managed systems, while the higher number of visits in more intensively-managed agroforests is associated with a higher frequency/length of stay of workers. Although both conversion of forests into agroforests and management intensification across agroforests affect invasion by domestic dogs, they influence distinct aspects, which may be associated with differences in the presence of people between these two habitats. In fact, in both environments (and not only in agroforests) visits by domestic dogs seem to be associated with the period of human activity, concentrating during the day, as observed in other studies (e.g. Srbeck- Araujo \& Chiarello, 2008; Paschoal et al., 2012) and on working days during the week.

\section{Implications for conservation}

Our results, as well as previous studies (Richardson et al., 2004; Faria et al., 2006; Bos et al., 2008; and Weis et al., 2010), indicate that, though permeable to wildlife (Tschnartke et al., 2005; Cassano et al., 2009), agroforests should act as sink areas, given the higher intensity of invasion compared to native forests, which should 
restrict the value commonly attributed to agroforests for biodiversity conservation (Schroth \& Harvey, 2007; Perfecto \& Vandermeer, 2008). More importantly, our study suggests that agroforest intensification, which has been occurring repeatedly and becoming more pronounced on a global scale (Juhrbandt et al., 2010; Tscharntke et al., 2011), should increase the risks of invasions, limiting the value of this agricultural system for reconciling food production and biodiversity conservation in a land-sharing strategy. Indeed, domestic dog record rate was one of the most important factors negatively associated with the distribution of wild mammals in agroforests of the study region (Cassano et al., 2012).

Furthermore, our study suggests - both by the association of the time and day of visits of domestic dogs with the periods of greater human activity, and by the observed distinct effects of the conversion of forests into agroforests and agroforest intensification on domestic dog invasion (on the number of individuals and visits, respectively) - that there is a strong association between the invasion by domestic dogs and human activities. Yet, the strength of association does not depend on the type of habitat, and apparently occurs also in unmanaged systems, like native forests.

As a whole, our work suggests that the value of agroforestry mosaics for conservation depends on the proper management of invasive species, and at least in the case of one of the most common and best distributed exotic species, this management should focus on the habits and behavior of workers and residents towards their dogs.

\section{Acknowledgments}

We thank G. de Oliveira, K.D. Espartosa, T. Puttker, P.K. Lira, C. de Barros, P. Torres, M.X. da Silva, T. Kubik, B.T. Pinotti, C. Pagotto, J.R. de Luca and P.E. Moraes for their help and companionship throughout the study; and the Instituto de Estudos Socioambientais do Sul da Bahia (IESB) for providing landscape maps. This study was funded by the European Union, the Brazilian Ministry of the Environment, CNPq (135312/2011-6) and Seeds of Change. EF was granted a MSc scholarship and CRC a PhD scholarship from FAPESP (2011/03113-5 and 2007/54888-1, respectively), and RP had a research fellowship from CNPq (Bolsa de Produtividade $306715 / 2011-2)$, during the development of this work. 


\section{References}

Baillie J.E.M., Hilton-Taylor C., Stuart S.N. (Eds). 2004. 2004 IUCN Red List of Threatened Species. A Global Species Assessment. IUCN, Gland, Switzerland and Cambridge, UK.

Balmford, A., Green, R.E., Scharlemann, J.P.W. 2005. Sparing land for nature: Exploring the potential impact of changes in agricultural yield on the area needed for crop production. Global Change Biology 11: 1594-1605.

Beer, J., Muschler, R., Kass, D., Somarriba, E. 1998. Shade management in coffee and cacao plantations. Agroforestry Systems 38: 134-164

Bhagwat, S.A., Willis, K.J., Birks, H.J.B., Whittaker, R.J. 2008. Agroforestry: A refuge for tropical biodiversity? Trends Ecol. Evol. 23: 261-267.

Bos, M.M., Tylianakis, J.M., Steffan-Dewenter, I., Tscharntke, T. 2008. The invasive Yellow Crazy Ant and the decline of forest ant diversity in Indonesian cacao agroforests. Biological Invasion 10: 1399-1409.

Burnham, K.P. \& Anderson, D.R. 2002. Model selection and multimodel inference. A practical information - theoretic approach. Springer, New York.

Cassano, C. R., Schroth, G., Faria, D., Delabie, J.H.C., Bede, L. 2009. Landscape and farm scale management to enhance biodiversity conservation in the cocoa producing region of southern Bahia, Brazil. Biodiversity and Conservation 18: 577-603.

Cassano, C.R., Barlow, J., Pardini, R. 2012. Large Mammals in an Agroforestry Mosaic in the Brazilian Atlantic Forest. Biotropica 1-8.

Cassano, C.R., Barlow, J., Pardini, R. In press. Forest loss or management intensification? Identifying causes of mammal decline in cacao agroforests. Biological Conservation.

Conover, M. 2002. Resolving human-wildlife conflicts: the science of wildlife damage management. Lewis Publishers, New York. 418p.

Cox, G.W. 1999. Alien species in North America and Hawaii. Island Press, Washington, D.C.

Creel, S. \& Christianson, D. 2008. Relationships between direct predation and risk effects. Tree 23: 194-201.

D’Antonio, C.M. \& Meyerson, L.A. 2002. Exotic plant species as problems and solutions in ecological restoration: a synthesis. Restoration Ecology 10: 703-713. 
Faria, D., Laps, R. R., Baumgarten, J., Cetra, M. 2006. Bat and bird assemblages from forests and shade cacao plantations in two contrasting landscapes in the Atlantic forest of southern Bahia, Brazil. Biodiversity Conserv. 15: 587-612.

Foley, J.A., Defries, R., Asner, G.P., Barford, C., Bonan, G., Carpenter, S.R., Chapin, F.S., Coe, M.T., Daily, G.C., Gibbs, H.K., Helkowski, J.H., Holloway, T., Howard, E.A., Kucharik, C.J., Monfreda, C., Patz, J.A., Prentice, I.C., Ramankutty, N., Snyder, P.K. 2005. Global consequences of land use. Science 309: $570-574$.

Franzen, M. \& Borgerhoff-Mulder, M. 2007 Ecological, economic and social perspectives on cocoa production worldwide. Biodiversity and Conservation 16: 3835-3849.

Green, R.E., Cornell, S.J., Scharlemann, J.P.W., Balmford, A. 2005. Farming and the fate of wild nature. Science 307: 550-555.

Gurevitch, J., Fox, G.A., Wardle, G.M., Inderjit, Taub, D. 2011. Emergent insights from the synthesis of conceptual frameworks for biological invasions. Ecology Letters 14: 407-418.

Hart, L. A. 2008. Dogs as human companions: a review of the relationship. In: The domestic dog. Its evolution behaviour, and interactions with people (Ed: J. Serpell). 161-178p. Cambridge University Press, Cambridge.

Hughes, J. \& Macdonald, D.W. 2013. A review of the interactions between freeroaming domestic dogs and wildlife. Biological Conservation 157:341-351.

Hulme, P.E. 2009. Trade, transport and trouble: managing invasive species pathways in an era of globalization. Journal of Applied Ecology 46: 10-18.

Jammalamadaka, S. R. \& SenGupta, A. 2001. Topics in Circular Statistics. World Scientific Press. Singapore.

Juhrbandt, J., Duwe, T., Barkmann, J., Gerold, G., Marggraf, R. 2010. Structure and management of cocoa agroforestry systems in Central Sulawesi across an intensification gradient. In: Tscharntke, T., Leuschner, C., Veldkamp, E., Faust, H., Guhardja, E., Bidin, A. (Eds.) Tropical rainforests and agroforests under global change. Springer. 519p

Khan, M. M. 2009. Can domestic dogs save humans from tigers Panthera tigris? Oryx 43: 44-47.

Koppen, W. 1948. Climatologia. Ed. Fondo Cultura Economica, Mexico City. 
Lacerda, A.C.R., Tomas, W.M., Marinho-Filho, J. 2009. Domestic dogs as an edge effect in the Brasília National Park, Brazil: interactions with native mammals. Animal Conservation 12: 477-487.

Lockwood, J.L., Cassey, P., Blackburn, T. 2005. The role of propagule pressure in explaining species invasions. Trends in Ecology and Evolution 20:223-228.

Mackenzie, D.I., Nichols, J.D., Lachman, G.B., Droege, S., Royle, J.A., Langtimm, C.A. 2002. Estimating site occupancy rates when detection probabilities are less than one. Ecology 83: 2248-2255.

Manor, R. \& Saltz, D. 2004. The impact of free-roaming dogs on gazelle kid/female ratio in a fragmented area. Biological Conservation, 119: 231-236.

May, S.A. \& Norton, T.W. 1996. Influence of fragmentation and disturbance on the potential impact of feral predators on native fauna in Australia forest ecosystems. Wildlife Research 23: 387-400.

McCarthy, M.A., Moore, J.L., Morris, W.K., Parris, K.M., Garrard, G.E., Vesk, P.A., Rumpff, L., Giljohann, K.M., Camac, J.S., Bau, S.S., Friend, T., Harrison, B., Yue, B. 2013. The influence of abundance on detectability. Oikos 0: 1-10.

McGeoch, M.A., Butchart, S.H.M., Spear, D., Marais, E., Kleynhans, E. J., Symes, A., Chanson, J., Hoffmann, M. 2010. Global indicators of biological invasion: species numbers, biodiversity impact and policy responses. Diversity and Distributions 16: 95-108

Mooney, H. A. \& Hobbs, R.J. 2000. Invasive species in a changing world. Island Press, Washington, DC.

Mori, S.A., Boom, B.M., Carvalho, A.M., Santos, T.S. 1983. Southern Bahian Moist Forests. Botanical Review 49: 1-155.

Newsome, A. E. \& Noble, I. R. 1986. Ecological and physiological characters of invading species. In: Groves, R.H. \& Burdon, J.J. (Eds). Ecology of Biological Invasions. Cambridge University Press, Cambridge, England. p 1-20.

Pardini, R., Faria, D., Accacio, G.M., Laps, R.R., Mariano-Neto, E., Paciência, M.L.B., Dixo, M., Baumgarten, J. 2009. The challenge of maintaining Atlantic forest biodiversity: A multi-taxa conservation assessment of specialist and generalist species in an agro-forestry mosaic in southern Bahia. Biol. Conserv. 142: $1178-1190$ 
Paschoal, A. M. O. 2008. Predadores em fragmentos de Mata Atlântica: estudo de caso na RPPN Feliciano Miguel Abdala, Caratinga, MG. Tese de Mestrado. Pontifícia Universidade Católica de Minas Gerais, Belo Horizonte, Brasil.

Paschoal, A. M. O., Massara, R. L., Santos, J. L.,Chiarello, A. G. 2012. Is the domestic dog becoming an abundant species in the Atlantic forest? A study case in southeastern Brazil. Mammalia 76: 67-76.

Perfecto, I., Vandermeer, J., Mas, A., Pinto, L.S. 2005. Biodiversity, yield, and shade coffee certification. Ecological Economics 54: 435-446.

Perfecto, I. \& Vandermeer, J. 2008. Biodiversity conservation in tropical agroecosystems - A new conservation paradigm. Ann. N.Y. Acad. Sci. 1134: 173200.

Phalan, B., Onial, M., Balmford, A., Green, R.E. 2011. Reconciliating food production and biodiversity conservation: Land sharing and land sparing compared. Science 333: 1289-1291.

Pimentel, D., Lach, L., Zuniga, R., Morrison, D. 2000. Costs of nonindigenous species in the United States. BioScience 50: 53-65.

R.2.11.0, The R Foundation for Statistical Computing. 2008, Viena, Austria.

Raizada, P., Raghubanshi, A.S., Singh, J.S. 2008. Impact of invasive alien plant species on soil processes: a review. Proceedings of the National Academy of Sciences India, Section B, Biological Sciences 78: 288-298.

Randall, D.A., Marino, J., Haydon, D.T., Sillero-Zubiri, C., Knobel, D.L., Tallents, L.A., Macdonald, D.W., Laurenson, M.K. 2006. An integrated disease management strategy for the control of rabies in Ethiopian wolves. Biological Conservation 131: 151-162.

Rice, R. A. \& Greenberg, R. 2000. Cacao cultivation and the conservation of biological diversity. Ambio 29: 167-173.

Richardson, D.M., Binggeli, P., Schroth, G. 2004. Invasive agroforestry trees: Problems and solutions. Agroforestry and biodiversity conservation in tropical landscapes 371-396.

Royle, J.A. 2004. N-mixture models for estimating population size from spatially replicated counts. Biometrics 60: 108-115.

Sala, O.E., Chapin, F.S., Armesto, J.J., Berlow, E., Bloomfield, J., Dirzo, R., HuberSanwald, E., Huenneke, L.F., Jackson, R.B., Kinzig, A., Leemans, R., Lodge, 
D.M., Mooney, H.A., Oesterheld, R., Poff, N.L., Sykes, M.T., Walker, B.H, Walker, M., Wall, D.H. 2000. Biodiversity - Global biodiversity scenarios for the year 2100. Science 287: 1770-1774.

Sambuichi, R.H.R. 2002. Fitossociologia e diversidade de espécies arbóreas em cabrucas (Mata Atlântica raleada sobre plantação de cacau) na região sul da Bahia, Brasil. Acta Botânica Brasilica 16: 89-101.

Schroth, G. \& Harvey, C.A. 2007. Biodiversity conservation in cocoa production landscapes: An overview. Biodiversity and Conservation 16: 2237-2244.

Schulze, C.H., Waltert, M., Kessler, P.J.A., Pitopang, R., Shahabuddin, D., Veddeler, D., Muhlenberg, M., Gradstein, S.R., Leuschner, C., Steffan-Dewenter, I., Tscharntke, T. 2004. Biodiversity indicator groups of tropical land use systems: Comparing plants, birds, and insects. Ecol. Appl. 14: 1321-1333.

SEI - Superintendência de Estudos Econômicos e Sociais da Bahia. 1999. Diagnóstico Ambiental, Litoral Sul da Bahia. Série de Estudos e Pesquisas 43: 1120.

Serpell, J. 2008. The domestic dog. Its evolution, behaviour, and interactions with people. Cambridge University Press, Cambridge. 268p.

Sher, A.A. \& Hyatt, L.A. 1999. The disturbed resource-flux invasion matrix: a new framework for patterns of plant invasion. Biological Invasions 1: 107-114.

Smallwood, K.S. 1994. Site invasibility by exotic birds and mammals. Biological Conservation 69: 251-259.

Somarriba, E. 1992. Revisiting the past - An essay on agroforestry definition. Agroforestry Systems 19: 233-240.

Srbek-Araujo A. C., Chiarello A. G. 2008. Domestic dogs in Atlantic forest preserves of south-eastern Brazil: a camera-trapping study on patterns of entrance and site occupancy rates. Brazilian Journal of Biology 68: 771-779.

Thomas, W.W. 2003. Natural vegetation types in southern Bahia. In: Prado, P.I., Landau, E.C., Moura, R.T., Pinto, L.P., Alger, K., Fonseca, G. (Eds.) Corredor de Biodiversidade da Mata Atlântica do sul da Bahia. Publicação em CD-ROM, Ilhéus, IESB/CI/CABS/UFMG/UNICAMP.

Tscharntke, T., Klein, A. M., Kruess, A., Steffan-Dewenter, I., Thies, C.. 2005. Landscape perspectives on agricultural intensification and biodiversity Ecosystem service management. Ecol. Lett. 8: 857-874. 
Tscharntke, T., Clough Y., Bhagwat, S.A., Buchori, D., Faust, H., Hertel, D., Holscher, D., Juhtbandt, J., Kessler, M., Perfecto, I., Scherber, C., Schroth, G., Veldkamp, E., Wanger, T.C. 2011. Multifunctional shade-tree management in tropical agroforestry landscapes - A review. J. Appl. Ecol. 48: 619-629.

Tylianakis, J.M., Tscharntke, T., Klein, A.M. 2006. Diversity, ecosystem function, and stability of parasitoid-host interactions across a tropical habitat gradient. Ecology 87: 3047-3057

Vanak, A. T. \& Gompper, M. E. 2009. Dogs Canis familiaris as carnivores: their role and function in intraguild competition. Mammal Rev. 39(4): 265-283.

Vanak, A. T. \& Gompper, M. E. 2010. Interference competition at the landscape level: the effect of free-ranging dogs on a native mesocarnivore. Journal of Applied Ecology, 47: 1225-1232.

Vitousek, P.M., D’Antonio, C.M., Loope, L.L., Rejmánek, M., Westbrooks, R. 1997. Introduced species: a significant component of human-caused global change. New Zealand Journal of Ecology 21: 1-16.

Waltert, M., Bobo, K.S., Kaupa, S., Montoya, M.L., Nsanyi, M.S., Fermon, H. 2011. Assessing conservation values: Biodiversity and endemicity in tropical land use systems. Plos One 6: e16238.

Wandeler, A.I., Matter, H.C., Kappeler, A., Budde, A. 1993. The ecology of canine rabies: a selective review. Rev. Sci. Tech. Off Int. Epiz. 12: 51-71.

Weist, M., Tscharntke, T., Sinaga, M.H., Maryanto, I., Clogh, Y. 2010. Effect of distance to forest and habitat characteristics on endemic versus introduced rat species in agroforest landscapes of Central Sulawesi, Indonesia. Mammalian Biology 75: 567-571.

Wilkie, D. 1983. Rayleigh Test for randomness of circular data. Journal of the Royal Statistical Society 32: 311-312.

Young, J. K., Olson, K. A., Reading, R. P., Amgalanbaatar, S., Berger, J. 2011. Is wildlife going to the dogs? Impacts of feral and free-roaming dogs on wildlife populations. BioScience 61: 125-132. 


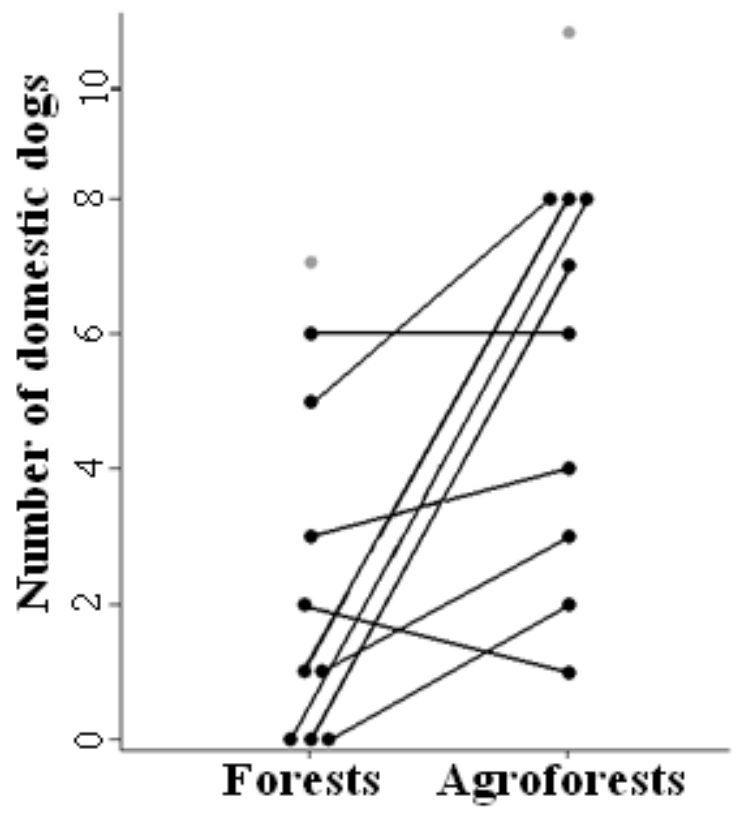

Figure 1: Number of domestic dogs recorded in nine pairs of agroforests and adjacent forests. Values of adjacent sampling sites are interconnected. Dots in grey represent estimates obtained by the selected abundance model (Table S2). 


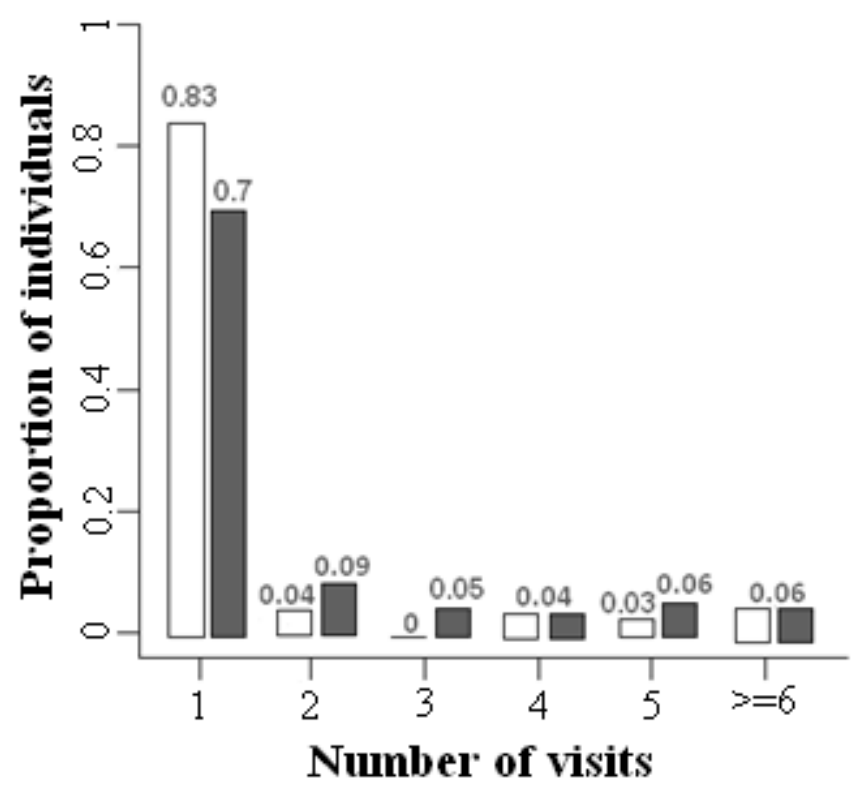

Figure 2: Proportion of domestic dogs in classes of number of visits in nine pairs of agroforests (grey) and adjacent forests (white). Number of visits excludes the sequential records of the same individual in the same camera. 


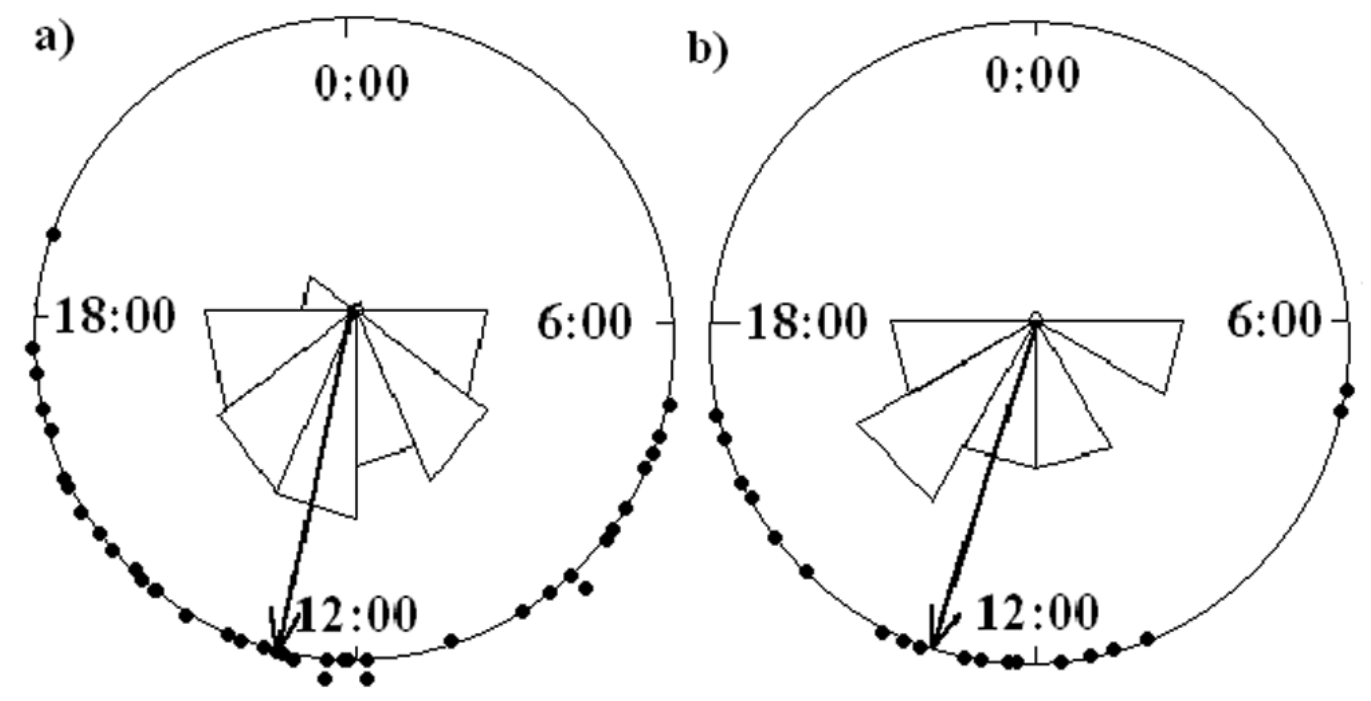

Figure 3: Time of visits by domestic dogs to nine pairs of (a) agroforests and (b) adjacent forests. Arrow: time at which visits concentrate; triangles: number of visits per 2-hour intervals. 
a)

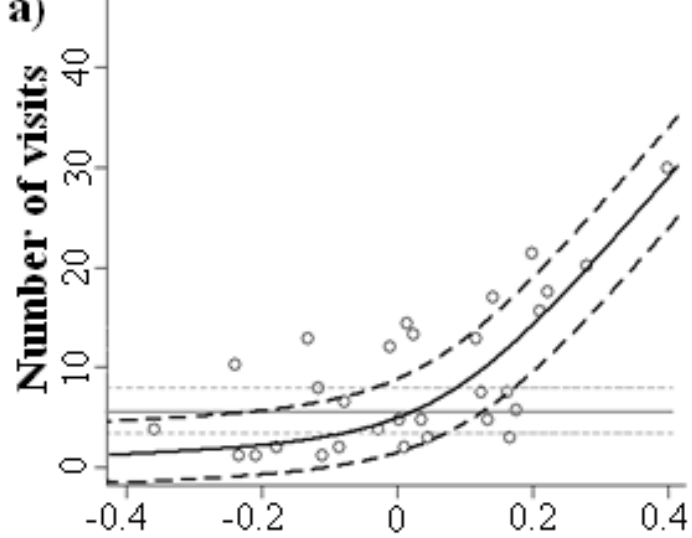

b)

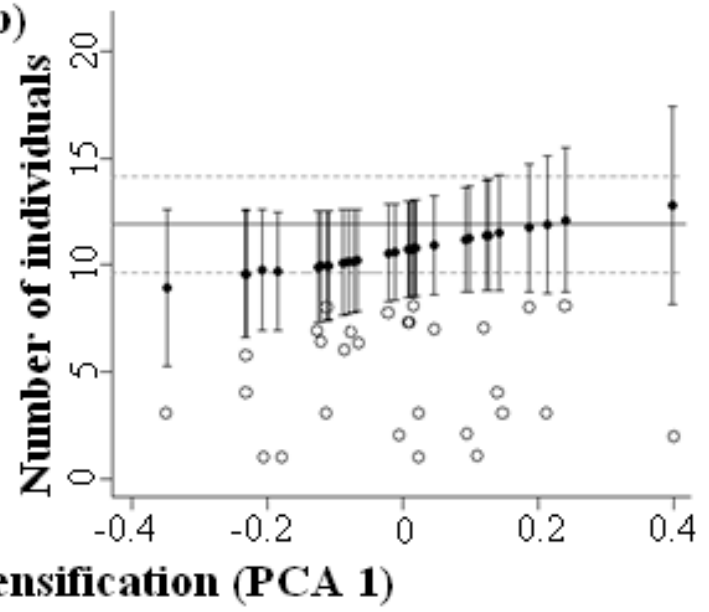

Figure 4: (a) Number of visits and (b) of individuals of domestic dogs as a function of management intensification (PCA1, Figure S2) across 30 agroforests. Empty dots: observed numbers; solid line or filled dots: estimates from models with management intensification as a co-variable (Tables S4 and S5); black bars and black dashed lines: standard deviations of these estimates; grey solid line: estimates from models with only sampling effort as a co-variable; grey dashed lines: standard deviation of these estimates. 


\section{Supplementary Material}

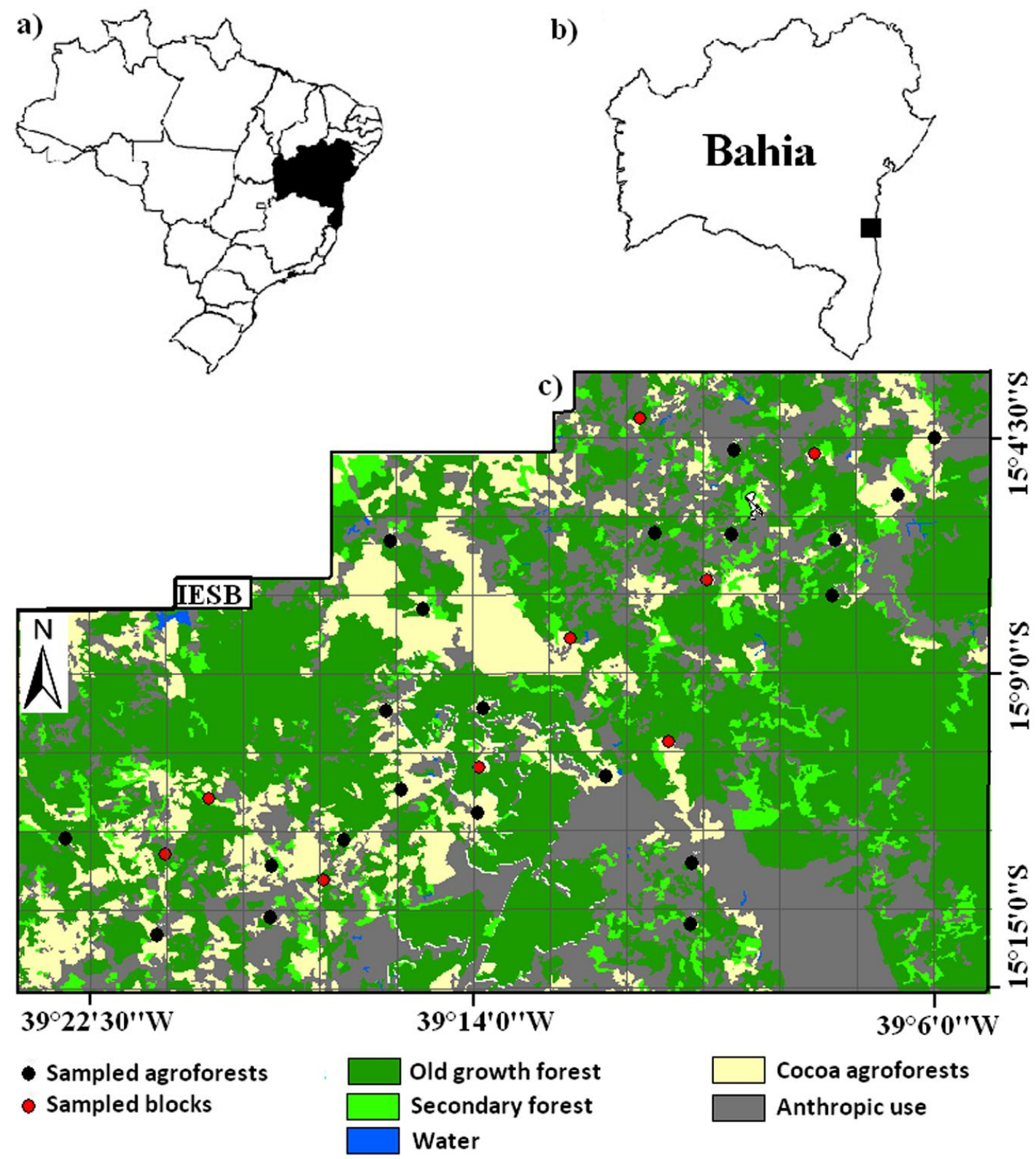

Figure S1: (a) Map of Brazil outlining the State of Bahia. (b) Map of Bahia showing the location of the study agroforestry mosaic (black square). c) Land use in the study agroforestry mosaic, situated in Una and Arataca, with 50\% forest cover and $15 \%$ cacao agroforests. 


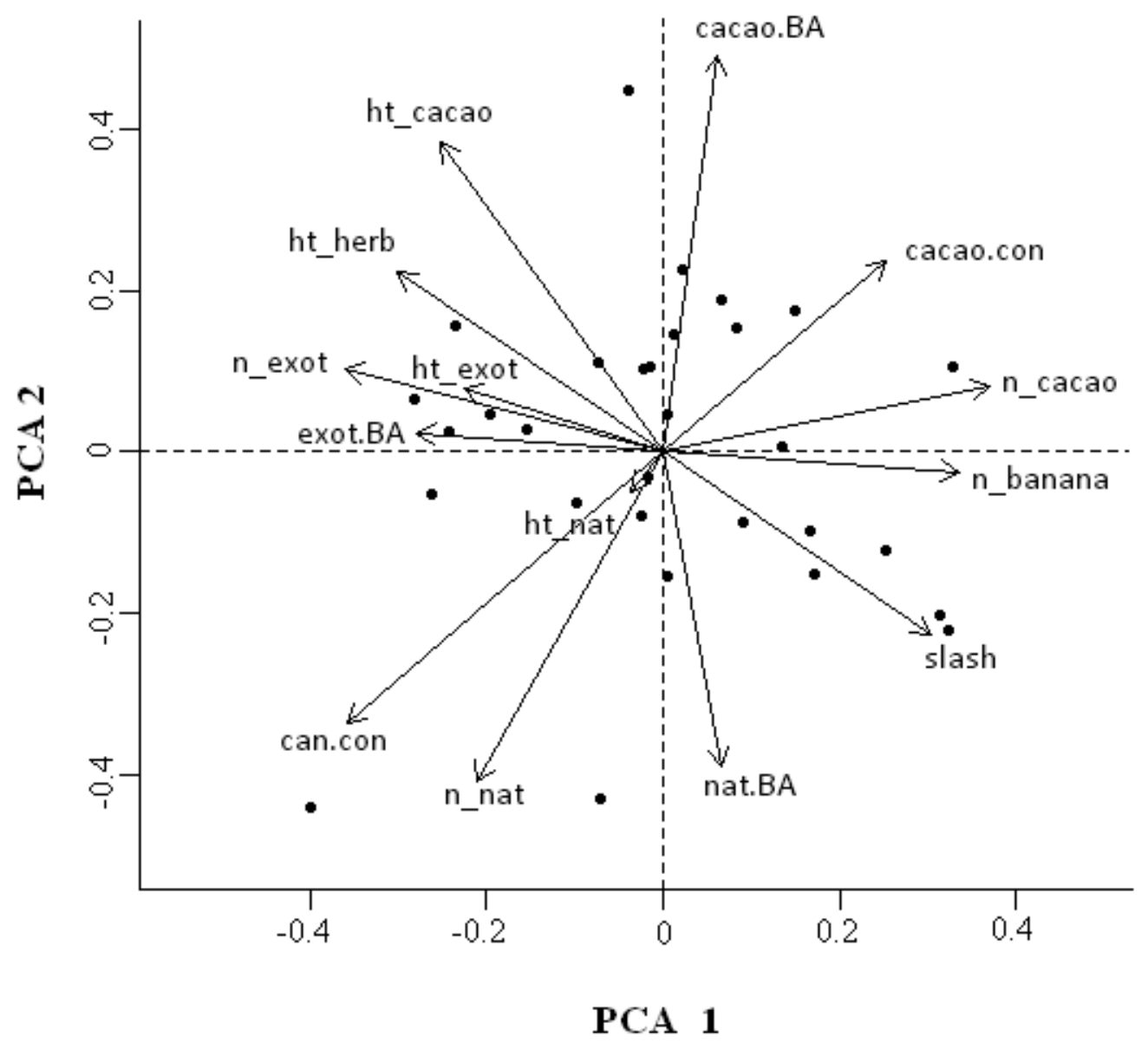

Figure S2: Ordination of the 30 sampled agroforests (black dots) on a biplot of the first and second axes of the Principal Component Analysis (PCA) using the 14 vegetation structure variables (Table S1). 
Table S1: Identification of the 14 variables of vegetation structure quantified in 30 agroforests to characterize management intensification

\begin{tabular}{ll}
\hline Variable identification & Variable description \\
\hline ht_cacao & Average height of cacao shrubs $(\mathrm{cm}) \dagger$ \\
ht_exot & Average height of exotic woody trees $(\mathrm{cm}) \dagger$ \\
ht_nat & Average height of native trees $(\mathrm{cm}) \dagger$ \\
ht_herb & Average herbaceous vegetation height $(\mathrm{cm})$ \\
cacao.BA & Sum of basal area of cacao shrubs $\left(\mathrm{m}^{2}\right) \dagger$ \\
exot.BA & Sum of basal area of exotic woody trees $\left(\mathrm{m}^{2}\right) \dagger$ \\
nat.BA & Sum of basal area of native trees $\left(\mathrm{m}^{2}\right) \dagger$ \\
n_cacao & Number of cacao shrubs $\dagger$ \\
n_exot & Number of exotic woody trees $\dagger$ \\
n_nat & Number of native trees $\dagger$ \\
n_banana & Number of banana stems $\dagger$ \\
can.con & Sum of canopy connectivity index $\dagger$ \\
cacao.con & Sum of cacao connectivity index $\dagger$ \\
slash & Frequency of herbaceous vegetation clearance (times*year \\
\hline
\end{tabular}

$\dagger$ Variables measured in $0.1 \mathrm{ha} ;+$ variables measured in 0.05 ha

Table S2: Results from the selection of abundance models for domestic dogs in nine pairs of agroforests and adjacent forests. Models are ordered from the most plausible (the lowest to the highest AICc value), and the selected model is highlighted (light grey). For each model, information is provided on the modeled parameter, number of parameters (K), maximum likelihood estimation (log-Lik), Akaike Information Criterion for small samples (AICc), difference in AICc relative to the best model $(\triangle \mathrm{AICc})$, weight of evidence (Wi), and coefficients of co-variables (+ positive; negative $)$. Eff= Sampling Effort

\begin{tabular}{lcccccccc}
\hline \multicolumn{1}{c}{ Models } & Par. & \multirow{2}{*}{ K } & log-Lik & AICc & AAIC & Wi & \multicolumn{2}{c}{ Coefficients } \\
\hline Eff + habitat type & $r, \lambda$ & 5 & $-36,25$ & 87,5 & 0 & 0,700 & - & + \\
Constant & - & 3 & $-41,29$ & 90,3 & 2,9 & 0,153 & & \\
Eff + cabruca-forest & $r, \lambda$ & 5 & $-37,85$ & 90,7 & 3,2 & 0,121 & - & + \\
Eff & $\mathrm{r}$ & 4 & $-41,01$ & 93,1 & 5,6 & 0,026 & & + \\
\hline
\end{tabular}


Table S3: Observed and expected number of visits by dogs in forests (a) and agroforests (b) on working days (Monday to Saturday) and rest days (Sunday). The expected value was calculated through the proportion of week days in each class (work and rest).

\begin{tabular}{ccccc}
\hline a) Forest & \multicolumn{3}{c}{ Observed } & \multicolumn{3}{c}{ Expected } \\
\cline { 2 - 5 } & $\mathbf{n}$ & $(\%)$ & $\mathbf{n}$ & $(\%)$ \\
\hline Working days & 17 & $(94)$ & 6 & $(86)$ \\
Rest days & 1 & $(6)$ & 1 & $(14)$ \\
Total & 18 & $(100)$ & 7 & $(100)$ \\
\hline
\end{tabular}

b) Agroforests

\begin{tabular}{ccccc}
\hline & \multicolumn{2}{c}{ Observed } & \multicolumn{2}{c}{ Expected } \\
\cline { 2 - 5 } & $\mathbf{n}$ & $(\%)$ & $\mathbf{n}$ & $(\boldsymbol{\%})$ \\
\hline Working days & 61 & $(94)$ & 6 & $(86)$ \\
Rest days & 4 & $(6)$ & 1 & $(14)$ \\
Total & 65 & $(100)$ & 7 & $(100)$ \\
\hline
\end{tabular}

Table S4: Results from the selection of generalized linear models of the number of visits of domestic dogs across 30 agroforests. Models are ordered from the most plausible (the lowest to the highest value of AICc), and the selected models are highlighted (light grey). For each model, information is provided on the modeled parameter ( $\mu=$ average), the number of parameters $(\mathrm{K})$, maximum likelihood estimation (log-Lik), Akaike Information Criterion for small samples (AICc), difference in AICc relative to the best model ( $\triangle \mathrm{AICc})$, weight of evidence (Wi), and coefficients of co-variables (+ positive; - negative). Eff= Sampling Effort; PCA 1 and PCA 2 axes from Principal Component Analysis represent agroforestry intensification.

\begin{tabular}{lcccccccccc}
\hline \multicolumn{1}{c}{ Models } & Par. & K & log-Lik & AICc & UAIC & Wi & \multicolumn{3}{c}{ Coefficients } \\
\hline EFF + PCA1 & $\mu$ & 4 & $-101,70$ & 213,0 & 0 & 0,505 & + & \\
EFF & $\mu$ & 3 & $-103,90$ & 214,7 & 1,7 & 0,214 & & & + \\
Constant & - & 2 & $-105,34$ & 215,1 & 2,1 & 0,176 & & & \\
EFF + PCA1 + PCA2 & $\mu$ & 5 & $-102,47$ & 217,5 & 4,5 & 0,053 & + & - & + \\
EFF + PCA2 & $\mu$ & 4 & $-103,97$ & 217,6 & 4,6 & 0,051 & & - & + \\
\hline
\end{tabular}


Table S5: Results from the selection of abundance models for domestic dogs across 30 agroforests. Models are ordered from the most plausible (the lowest to the highest value of AICc), and the selected models are highlighted (light grey). For each model, information is provided about the modeled parameter $(\lambda=$ abundance; $r=$ probability of detection of the individual), number of parameters $(\mathrm{K})$, maximum likelihood estimation (log-Lik), Akaike Information Criterion for small samples (AICc), difference in AICc of relative to the best model ( $\triangle \mathrm{AICc}$ ), weight of evidence (Wi), and coefficients of co-variables (+ positive; - negative). Eff= Sampling Effort; PCA 1 and PCA 2 axes from Principal Component Analysis represent agroforestry intensification.

\begin{tabular}{lccccccccc}
\hline \multicolumn{1}{c}{ Models } & Par. & K & $\begin{array}{c}\text { log- } \\
\text { Lik }\end{array}$ & AICc & AAIC & Wi & \multicolumn{2}{c}{ Coefficients } \\
\hline EFF & $r$ & 4 & $-208,02$ & 425,6 & 0,000 & 0,636 & & + \\
EFF + PCA1 & $r, \lambda$ & 5 & $-207,87$ & 428,2 & 2,593 & 0,174 & + & & + \\
EFF + PCA2 & $r, \lambda$ & 5 & $-207,99$ & 428,4 & 2,849 & 0,153 & & - & + \\
EFF + PCA1 + PCA2 & $r, \lambda$ & 6 & $-207,84$ & 431,3 & 5,686 & 0,037 & + & - & + \\
Constant & - & 3 & $-216,52$ & 439,9 & 14,321 & 0,000 & & & + \\
\hline
\end{tabular}




\section{Considerações finais}

Este trabalho contribuiu para o entendimento das causas e consequências das invasões de cães domésticos em paisagens rurais antropizadas da Mata Atlântica, abordando a relação das invasões biológicas com a perda de habitat e a intensificação da agricultura. A partir dos resultados obtidos o trabalho trouxe informações que podem auxiliar a guiar ações que visem minimizar os impactos que cães domésticos podem causar à fauna silvestre de florestas tropicais.

Em primeiro lugar, o trabalho traz informações até então inexistentes sobre a intensidade da invasão de cães domésticos em paisagens antropizadas de Mata Atlântica. Evidenciamos que a intensidade de invasão, tanto de remanescentes florestais quanto de mosaicos agroflorestais, é altíssima, no que se refere ao número de indivíduos, número de visitas por indivíduos e número de sítios ocupados. Esta grande quantidade de cães deve representar uma séria ameaça às comunidades já empobrecidas e simplificadas (Chiarello, 1999; Cassano et al., 2012) de mamíferos de maior porte deste bioma. De fato, e de acordo com estudos anteriores (Lacerda, 2009; Cassano et al., in press), encontramos uma associação negativa entre a presença de cães domésticos e o registro de mamíferos silvestres. Ao incluir outros fatores nessas análises, no entanto, este estudo trouxe informações antes inexistentes sobre a importância da invasão por cães domésticos em relação à perda de habitat, considerada a principal ameaça a biodiversidade. Os resultados sugerem que um maior número de espécies de mamíferos de maior porte é negativamente afetado pela invasão do que pela perda de $40 \%$ de florestas na paisagem.

Este estudo também contribuiu no entendimento das causas da invasão, identificando os fatores associados à intensidade da invasão em paisagens antropizadas. Novamente, ao considerar vários fatores simultaneamente, foi possível demonstrar que características dos remanescentes associadas à perda e fragmentação das florestas são muito mais importantes que a pressão de propágulo para definir a intensidade de invasão, e que a intensificação do manejo de áreas produtivas também leva ao aumento da invasão. Estas constatações são preocupantes visto que a intensificação de agroflorestas e outros sistemas agrícolas vem se acentuando globalmente (Juhrbandt et al., 2010; Tscharntke et al., 2011) e que, apesar da diminuição das taxas de desmatamento das florestas tropicais nos últimos anos (Wright \& 
Muller-Landau, 2006), a maior parte das áreas remanescentes é constituída de vegetação degradada ou secundária (Wright, 2005; Wright, 2010). Sendo assim, espera-se um aumento da quantidade de áreas susceptíveis à invasão por cães domésticos, e, consequentemente, dos danos causados por estes animais.

Por fim, mostramos que a invasão por cães é favorecida pelo tipo de manejo, em que os animais são criados soltos, e parece estar fortemente associada à presença do homem. Assim, o manejo adequado dos cães, incluindo os cuidados veterinários, é fundamental para minimizar os impactos desta espécie exótica.

\section{Referencias Bibliográficas}

Cassano, C.R., Barlow, J., Pardini, R. 2012. Large Mammals in an Agroforestry Mosaic in the Brazilian Atlantic Forest. Biotropica 1-8.

Cassano, C.R., Barlow, J., Pardini, R. In press. Forest loss or management intensification? Identifying causes of mammal decline in cacao agroforests. Biological Conservation .

Chiarello, A.G. 1999. Effects of fragmentation of the Atlantic Forest on mammal communities in south-eastern Brazil. Biological Conservation 89: 71-82.

Juhrbandt, J., Duwe, T., Barkmann, J., Gerold, G., Marggraf, R. 2010. Structure and management of cocoa agroforestry systems in Central Sulawesi across an intensification gradient. In: Tscharntke, T., Leuschner, C., Veldkamp, E., Faust, H., Guhardja, E., Bidin, A. (Eds.) Tropical rainforests and agroforests under global change. Springer. 519p.

Lacerda, A.C.R., Tomas, W.M., Marinho-Filho, J. 2009. Domestic dogs as an edge effect in the Brasília National Park, Brazil: interactions with native mammals. Animal Conservation 12: 477-487.

Tscharntke, T., Clough Y., Bhagwat, S.A., Buchori, D., Faust, H., Hertel, D., Holscher, D., Juhtbandt, J., Kessler, M., Perfecto, I., Scherber, C., Schroth, G., Veldkamp, E., Wanger, T.C. 2011. Multifunctional shade-tree management in tropical agroforestry landscapes - A review. J. Appl. Ecol. 48: 619-629

Wright, S. J. 2005. Tropical forests in a changing environment. Trends in Ecology and Evolution. 20: 553-560.

Wright, S. J., \& Muller-Landau, H. C. 2006. The future of tropical forest species. Biotropica 38: 207-301. 
Wright, S. J., 2010. The future of tropical forests. Annals of the New York Academy of Science 1195: 1-27. 